system for retrievability purposes.

11. Receiver Remarks:

For release.
11A. Design Baseline Document? [] Yes $[X]$ No [] Yes $[X]$ No

\begin{tabular}{|l|l|}
\hline \multicolumn{1}{|c|}{$\begin{array}{l}\text { 2. To: (Receiving Organization) } \\
\text { Distribution }\end{array}$} & $\begin{array}{l}\text { 3. From: (Originating Organization) } \\
\text { Operations Configuration } \\
\text { Management/Field Upgrade }\end{array}$ \\
\hline $\begin{array}{l}\text { 5. Proj./Prog./Dept./Div.: } \\
\text { 244-AR Vault/River } \\
\text { Protection Project/Op. } \\
\text { Config. Mgmt./Proc. Trng. \& }\end{array}$ & $\begin{array}{l}\text { 6. Design Authority/ Design Agent/Cog. } \\
\text { Engr.: T. Laney }\end{array}$ \\
Ops. & \\
\hline $\begin{array}{l}\text { 8. originator Remarks: } \\
\text { This document is being released into the supporting document } \\
\text { system for retrievability purposes. }\end{array}$
\end{tabular}

4. Related EDT No.:

$\mathrm{N} / \mathrm{A}$

7. Purchase Order No.:

$\mathrm{N} / \mathrm{A}$

9. Equip./Component No.:

$\mathrm{N} / \mathrm{A}$

10. System/Bldg./Facility: $244-\mathrm{AR}$

12. Major Assm. Dwg. No.:

$\mathrm{N} / \mathrm{A}$

13. Permit/Permit Application No.: N/A

14. Required Response Date: $03 / 23 / 00$

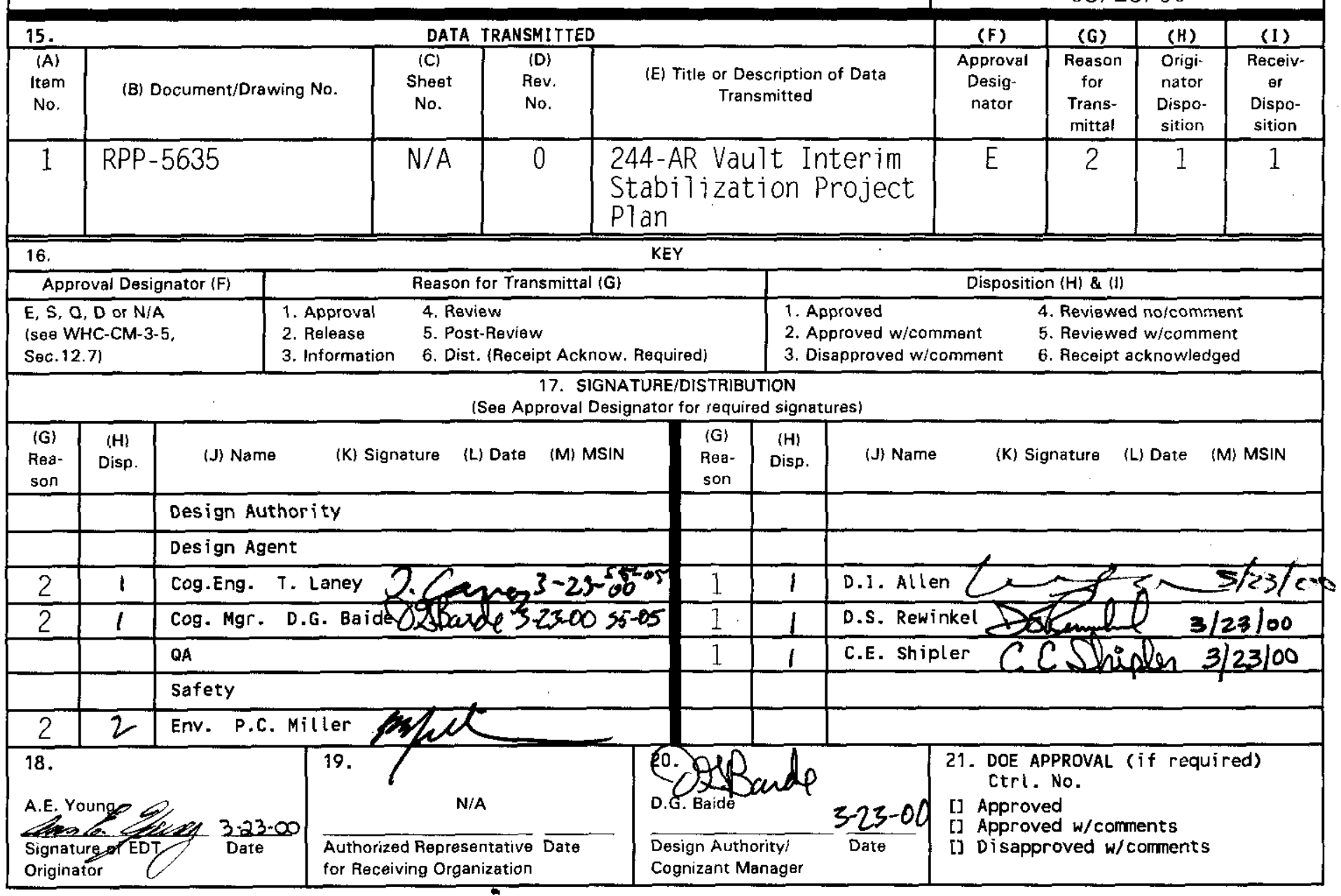


RPP-5635

Revision 0

\section{4-AR Vault Interim Stabilization Project Plan}

Prepared for the U.S. Department of Energy Assistant Secretary for Environmental Management

\section{CH2MHILL Hanford Group, Inc.}

Richland, Washington

Contractor for the U.S. Department of Energy

Office of River Protection under Contract DE-AC06-99RL14047

Approved for Public Release; Further Dissemination Unlimited 
LEGAL DISCLAIMER

This report was prepared as an account of work sponsored by an agency of the United States Government. Neither the United States Government nor any agency thereof, nor any of their employees, nor any of their contractors, subcontractors or their employees, makes any warranty, express or implied, or assumes any legal liability or responsibility for the accuracy, completeness, or any third party's use or the results of such use of any information, apparatus, product, or process disclosed, or represents that its use would not infringe privately owned rights. Reference herein to any specific commercial product, process, or service by trade name, trademark, manufacturer, or otherwise, does not necessarily constitute or imply its endorsement, recommendation, or favoring by the United States Government or any agency thereof or its contractors or subcontractors. The views and opinions of authors expressed herein do not necessarily state or reflect those of the United States Government or any agency thereof.

This report has been reproduced from the best available copy.

Available in paper copy and microfiche.

Available electronically at http:/www.doe.gov/bridge. Available for a processing fee to the U.S. Department of Energy and its contractors, in paper, from:

U.S. Department of Energy

Office of Scientific and Technical Information

P.O. Box 62

Oak Ridge, TN 37831-0062

phone: $865-576-8401$

fax: $865-576-5728$

email: reports(a)adonis.osti.gov(423) 576-8401

Available for sale to the public, in paper, from:

U.S. Department of Commerce

National Technical Information Service

5285 Port Royal Road

Springfield, VA 22161

Phone: 800-553-6847

fax: 703-605-6900

email: orders@ntis.fedworld.gov

online ordering:

http://www.ntis.gov/ordering.htm 
RPP-5635

Revision 0

\section{4-AR Vault Interim Stabilization Project Plan}

Prepared by:

Numatec Hanford Corporation

Richland, Washington

TRW Environmental Systems

Richland, Washington

Fluor Federal Services

Richland, Washington

Parsons Infrastructure \& Technology Group

Richland, Washington

Date Published

March 2000

\section{CH2MHILL \\ Hanford Group, Inc.}

P. O. Box 1500

Richland, Washington

Contractor for the U.S. Department of Energy

Office of River Protection under Contract DE-AC06-99RL14047

Approved for Public Release; Further Dissemination Unlimited 


\section{4-AR Vault Interim Stabilization Project Plan}

T. Laney

CH2M HILL. Hanford Group, Inc., Richland, WA 99352

U.S. Department of Energy Contract DE-AC06-96RL13200

EDT/ECN: EDT-628386 UC: 2070

Org Code: 79800 CACN/COA: 111270/EJ00

B\&R Code: EW 3120074 Total Pages: 106

Key words: 244-AR Vault, 244-AR. Interim, Stabilization, Project Plan. Plan. Milestone M-45-11A. PI ORP 3.3.1

Abstract: $N / A$

TRADEMARK DISCLAIMER. Reference herein to any specific commercial product, process, or service by trade name, trademark, manufacturer, or otherwise, does not necessarily constitute or imply its endorsement, recommendation, or favoring by the United States Government or any agency thereof or its contractors or subcontractors.

Printed in the United States of America. To obtain copies of this document, contact: Document Control Services, P.0. Box 950, Mailstop H6-08, Richland HA 99352, Phone (509) 372-2420; Fax (509) 376-4989.
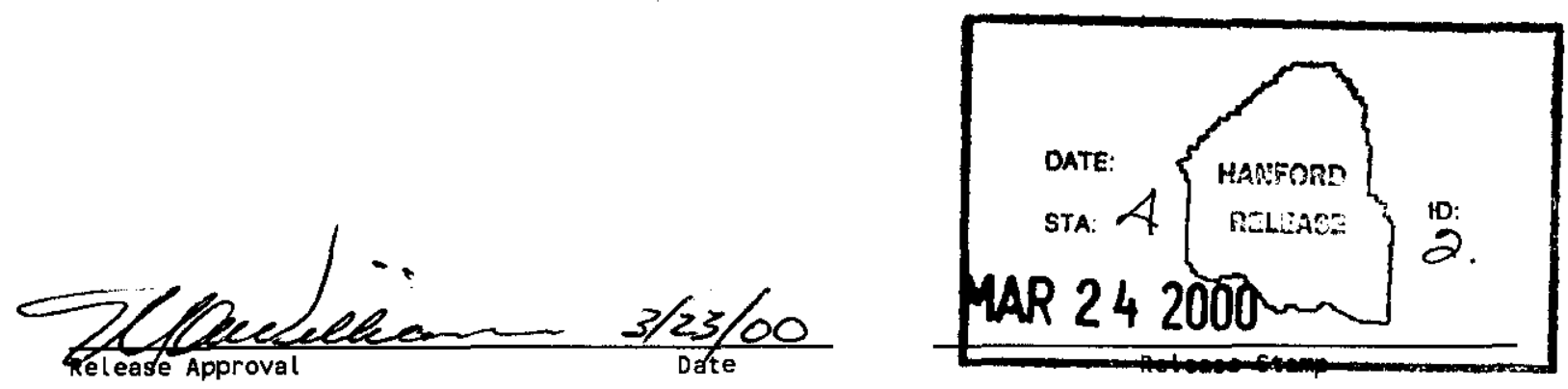

\section{Approved for Public Release}




\section{EXECUTIVE SUMMARY}

The 244-AR Vault Facility is a "canyon" facility housing four waste processing tanks in three belowgrade concrete cells. The facility originally was constructed between 1966 and 1968 to provide lag storage and treatment for the Plutonium Uranium Extraction Facility (PUREX). The last process transfers were made in support of that mission in the late 1970s. Modifications to the facility were initiated in 1984 to provide support for the vitrification program and the separation of the neutralized current acid waste (NCAW) into transuranic (TRU) and non-transuranic waste streams. The mission was cancelled in 1988, before the modifications were completed. The last transfer within the vault occurred in 1992. An effort to air jet the sumps to the tanks was begun in 1997 but was terminated prior to completion.

The 244-AR Vault Facility contains approximately $72,105 \mathrm{~L}$ (19,050 gal) of radioactive waste. The majority of the volume is anticipated to be contaminated water from intrusion of precipitation and snowmelt. Of the total volume, $60,750 \mathrm{~L}(16,050 \mathrm{gal})$ is contained in the four waste process tanks, and $11,355 \mathrm{~L}(3,000 \mathrm{gal})$ is in the concrete cells housing the tanks.

Historically, the instrumentation that measures the waste levels in the facility tanks and sumps has recorded unexplained changes in the waste levels. There are three open occurrence reports from the 1997 timeframe that document unexplained waste level changes in the sumps.

By design, ancillary facility components such as the vessel vent filter building and equipment pits drain liquids from leaks and condensation or intrusion from precipitation and snowfall to the 244-AR vault sumps. Facility logs show that, during facility operations and the facility modification in the mid 1980s, liquids accumulating in the sumps were frequently jetted to the process tanks. Facility logs show that the majority of the liquid contained in the 244-AR vault sumps is the result of precipitation and snowmelt intrusion, construction water used during the facility modification, and water resulting from a ruptured water line in early 1997.

In November 1999, the "interim stabilization" of the 244-AR Vault Facility was defined and the pending action was moved from the Hanford Federal Facility Agreement and Consent Order (TPA) Milestone M-32-00, "Complete Identified Dangerous Waste Tank Corrective Actions," to Milestone M-45-00, "Complete Closure of all Single-Shell Tanks." Two interim milestones were created: Interim Milestone M-45-11A requires submittal by April 30, 2000, of a 244-AR vault interim stabilization project plan to the Washington State Department of Ecology (Ecology) for approval. Interim Milestone M-45-11 added the requirement to complete 244-AR vault interim stabilization by September 30, 2003.

As a result of the agreement among the U.S. Department of Energy (DOE), Office of River Protection (ORP), and Ecology for the interim stabilization of the 244-AR Vault Facility, a performance incentive (PI) ORP3.3.1, was created for fiscal year (FY) 2000. This PI requires that a project plan for interim stabilization of the 244-AR vault be submitted to DOE-ORP by March 30, 2000.

This project plan provides a path forward for the interim stabilization of the 244-AR vault to meet the requirements set forth in TPA Milestone M-45-11A and reflected in PI ORP3.3.1. 
Following the evaluation of alternatives, this plan outlines the design and installation of a "temporary transfer system" into the 244-AR Vault Facility for removal of the pumpable liquids contained in the process tanks and sumps. This plan requires minimal refurbishment of the 244-AR Vault Facility and does not require the activation of the overhead bridge crane or reintroduction of steam to operate the jetting system. The temporary system consists of a common manifold to be located above the cover blocks of the cells inside the canyon building. Liquid will be pumped through the manifold from a series of pump legs that will be lowered into the respective tanks and sumps. Access to the cells will be created, where necessary, by core boring through the concrete cover blocks. Access to the tanks will be through an existing nozzle or by cutting a hole in the top of each tank with a high-pressure abrasive water-jet previously used at the Hanford Site.

In parallel to the pumping effort, the facility will be isolated from process liquid lines and waste transfer lines, and the intrusion paths will be mechanically blocked to prevent further intrusion of liquids into the $244-\mathrm{AR}$ vault.

\section{Scope}

The scope of the project is for the "interim stabilization" of the 244-AR Vault Facility as defined in TPA Change Control form M-45-99-02. The interim stabilization activities include the following requirements:

1. Removal of pumpable liquids from the 244-AR vault tanks

2. Removal of pumpable liquids from the 244-AR vault sumps

3. Isolation of the $244-\mathrm{AR}$ vault

4. Provisions for the removal of liquids which may accumulate in the future

5. Installation of intrusion prevention mechanisms as necessary

6. Establishment of liquid-level monitoring to detect future intrusions.

A requirements matrix for these activities is provided in Appendix A.

\section{Schedule}

The schedule to execute the project plan has not yet been defined and depends on the allocation of funding. The project requires a duration of 32 months to meet the TPA milestone of September 30, 2003. Figure 6-2 provides a detailed schedule assuming a project start date of October 1, 2000. 


\section{RPP-5635 REV 0}

\section{Cost}

The estimate to provide interim stabilization of the 244-AR Vault Facility is $\$ 6.46$. Pending the schedule for execution of the project, the FY funding estimate is as follows:

\begin{tabular}{|l|c|c|c|c|}
\hline & FY 2001 & FY 2002 & FY 2003 & Total \\
\hline Total Escalated Cost $(\$ 000)$ & $4,447.9$ & $1,754.4$ & 258.4 & $6,460.7$ \\
\hline
\end{tabular}

A detailed cost breakdown provided in Section 6.5 assumes a project start of October 1, 2000.

The project, when completed, will result in the interim stabilization of the 244-AR Vault Facility. The execution of the project plan work will complete TPA Interim Milestone M-45-11. 
RPP-5635 REV 0

This page intentionally left blank.

ES-4 
TABLE OF CONTENTS

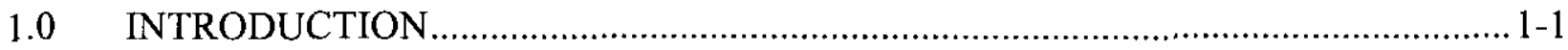

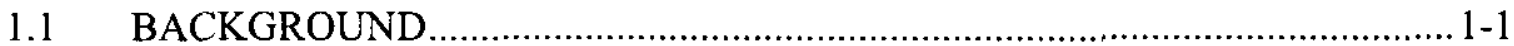

1.2 TRI-PARTY AGREEMENT MILESTONE M-45-11A DELIVERABLES ........ 1-2

1.3 PERFORMANCE INCENTIVE ORP3.3.1 DELIVERABLES ........................1-2

1.4 OVERALL PLANNING APPROACH AND THE FOCUSED TASK

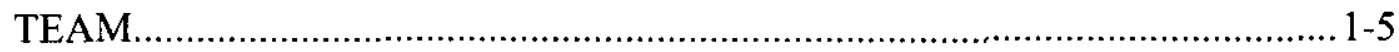

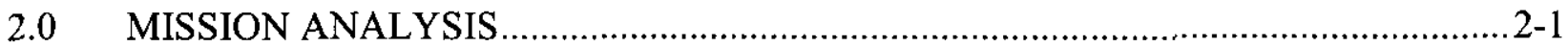

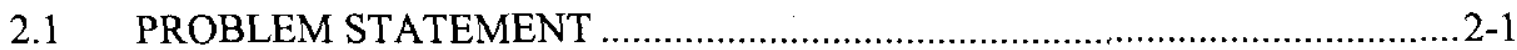

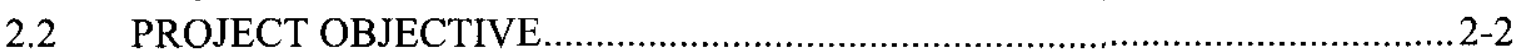

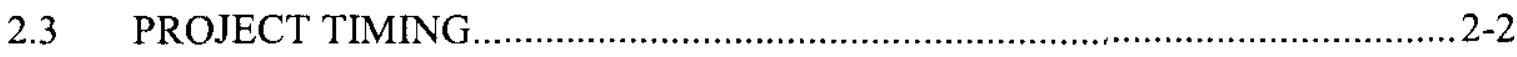

2.4 PROJECT BOUNDARIES AND INTERFACES ...........................................2-3

2.4.1 External Interfaces............................................................................ 2-3

2.4.2 Programmatic Interfaces ..................................................................2-3

2.4.3 Potential Effects on Other River Protection Project Programs .................2-3

2.4.4 Facility Boundaries ........................................................................... 2-5

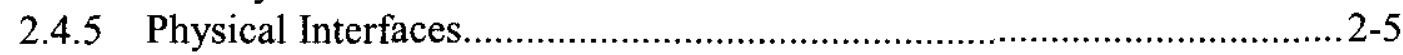

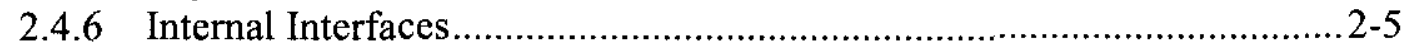

2.4.7 Other Site Projects............................................................................... 2-7

2.4.8 Inputs and Outputs ............................................................................ 2-7

$2.5 \quad$ BEGINNING STATES AND ENDING STATES ……............................... 2-8

2.5.1 Facility Configuration ........................................................................

2.5.2 Current Tank/Sump Liquid Conditions.................................................. 2-11

2.5.3 Liquid Conditions Through Interim Stabilization..................................2-14

2.5.4 Stabilized Facility Configuration …………….....................................2-14

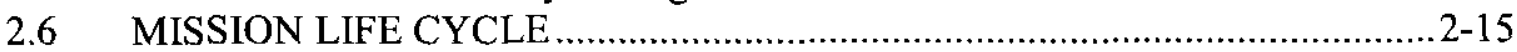

2.6.1 Program Planning ......................................................................... 2-15

2.6.2 Conceptual Design ........................................................................ 2-15

2.6.3 Preliminary Design .........................................................................

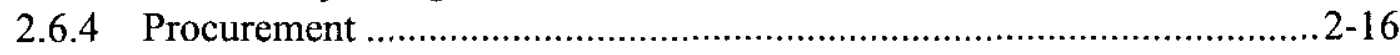

2.6.5 Final Design ...............................................................................

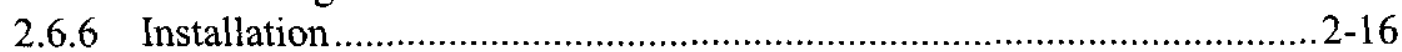

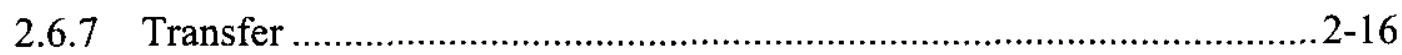

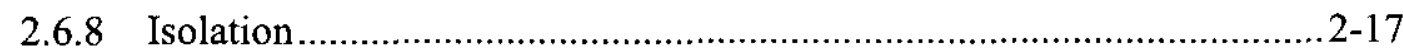

2.6.9 Intrusion Prevention ................................................................... 2-17

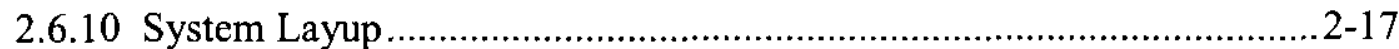

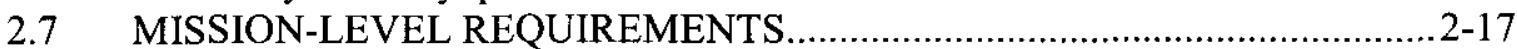

2.8 OBJECTIVES AND MEASURES OF SUCCESS .......................................... 2-18

2.9 STABILIZATION OPTIONS AND EVALUATION ……...............................2-18

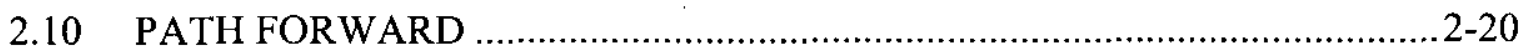

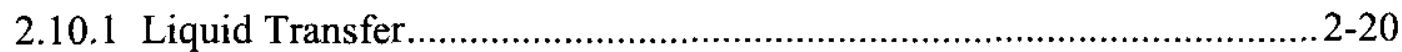

2.10.2 Isolation and Intrusion Prevention ..............................................2-20

2.10.3 Facility Monitoring ........................................................................2-21

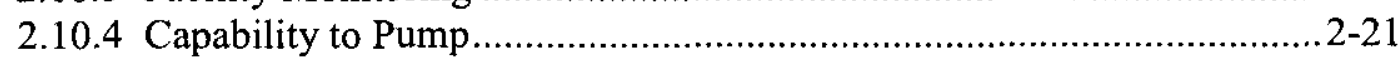




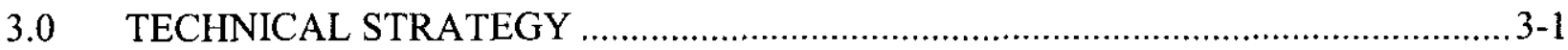

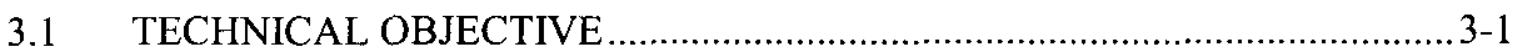

3.1.1 Liquid Removal............................................................................... 3-1

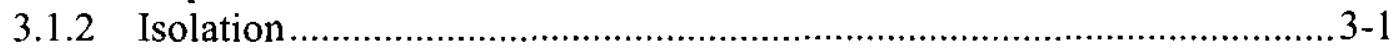

3.1.3 Intrusive Prevention ..................................................................... 3-1

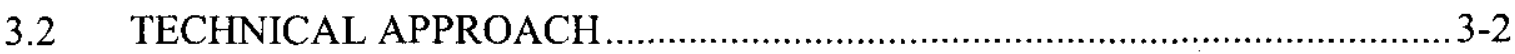

3.2.1 Waste Consolidation and Transfer System ............................................ 3-2

3.2.2 Waste Transfer and Process Line Isolation ............................................... 3-7

3.2.3 Intrusion Prevention ................................................................... 3-9

3.2.4 Monitoring............................................................................... 3-11

3.2.5 Provisions for Future Pumping ....................................................... 3-11

3.2.6 Use of Existing Technology........................................................... 3-11

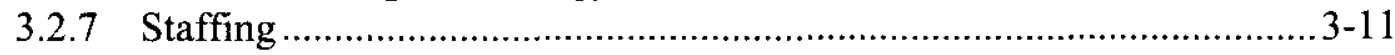

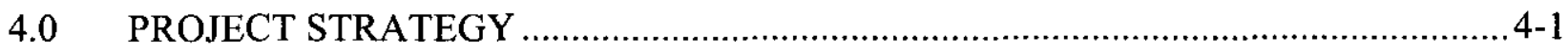

4.1 OPERATIONS AND MAINTENANCE ……............................................

4.1.1 Operations Strategy ...................................................................... $4-1$

4.1.2 Maintenance Strategy ................................................................... 4-1

4.2 NUCLEAR SAFETY AND LICENSING ……...................................... 4-2

4.2.1 Nuclear Safety Analysis Process ............................................................. 4-2

4.2.2 Authorization-Basis Documentation and Licensing Actions ....................4-2

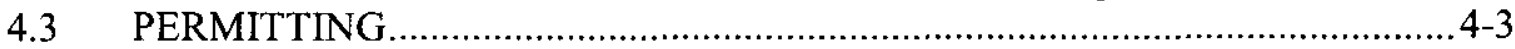

4.3.1 Assumptions ................................................................................. 4-3

4.3.2 National Environmental Policy Act ....................................................... 4-3

4.3.3 Resource Conservation and Recovery Act (RCRA) ……........................ 4-4

4.3.4 Clean Air Act (CAA) ..................................................................... 4-4

4.4 READINESS ASSESSMENT ……………........................................... $4-4$

$5.0 \quad$ ASSUMPTIONS AND RISK …………………..................................................

$5.1 \quad$ KEY ASSUMPTIONS .....................................................................

5.1.1 Project Assumptions ........................................................................ 5-1

5.1.2 Operating Assumptions ........................................................................5-1

5.2 ENABLING ASSUMPTIONS ……………............................................... 5-2

5.2.1 Operating Enabling Assumptions........................................................... 5-2

5.2.2 Equipment Enabling Assumptions …………........................................ 5-3

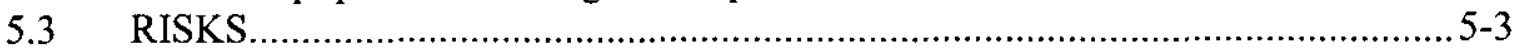

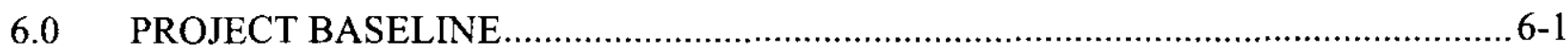

6.1 PLANNING PROCESS ............................................................................. 6-1

6.2 PROJECT WORK BREAKDOWN STRUCTURE ………….........................6-2

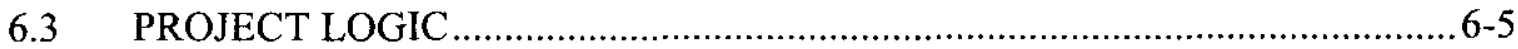

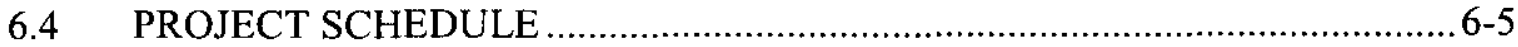

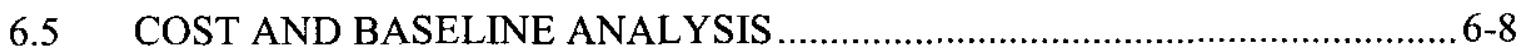

6.5.1 Cost by Work Breakdown Structure ....................................................... 6-8

6.5.2 Labor Resources by Work Breakdown Structure................................... 6-10

6.5.3 Baseline Risk Analysis.................................................................... 6-11

6.6 PROCUREMENT ACTIVITIES ............................................................. 


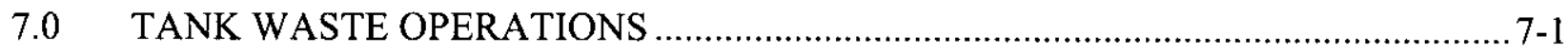

7.1 TANK FARM FACILITIES OPERATIONS ……........................................ $7-1$

7.2 POST-STABILIZATION OPERATIONS...................................................

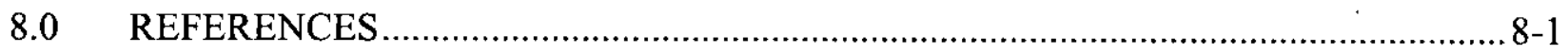

\section{APPENDICES}

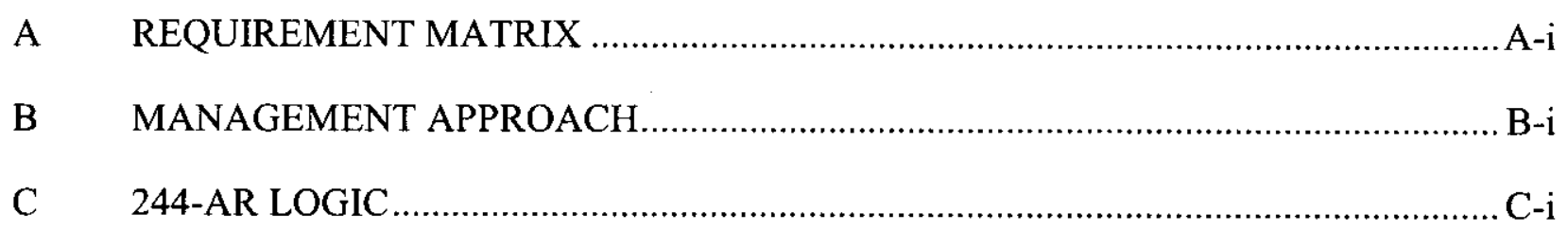

\section{FIGURES}

Figure 1-1. Federal Facility Agreement and Consent Order Change Control Form M-45-99-02.

Figure 1-1. Federal Facility Agreement and Consent Order Change Control Form M-45-99-02.

Figure 2-1. Current Tank and Sump Liquid Levels. ............................................................2-2

Figure 2-2. 244-AR Canyon Stabilization Activity Boundaries and Interfaces.........................2-4

Figure 2-3. 244-AR Vault Facility Boundary. …………...................................................... 2-6

Figure 2-4. 244-AR Construction (General Layout).................................................................

Figure 2-5. 244-AR Construction (General Layout)........................................................... 2-10

Figure 2-6. Project Execution and Engineering Management Planning. .................................2-15

Figure 3-1. 244-AR Vault: Temporary Transfer System Diagram. ..........................................3-3

Figure 3-2. 244-AR Waste Removal Concept Cell Access/Core Drill Locations. .......................3-5

Figure 3-3. Waste Transfer and Process Line Isolation Points................................................. 3-8

Figure 3-4. 244-AR Vault Intrusion Boundary ………...................................................... 3-10

Figure 6-1. 244-AR Vault Interim Stabilization Project Work Breakdown Structure................6-3

Figure 6-2. 244-AR Vault Interim Stabilization Project Schedule ..............................................6-6 
RPP-5635 REV 0

Figure 6-3. Category I, II, and III Project Cost Drivers for Completion of Project.

Figure 6-4. Category I, II, and III Project Schedule Drivers for Completion of Project. $6-14$

Figure 7-1. Tank Waste Operations Organization Chart. $7-2$

Figure 7-2. SY Farm Project Team. $7-3$

\section{TABLES}

Table 2-1. Summary of Volumes of Material Estimated to Remain in 244-AR Vault 2-11

Table 2-2. Best Estimate of Material in the Tanks of 244-AR Vault................................2-12

Table 2-3. Hanford Defined Waste Stream for 244-AR Vault. .........................................2-13

Table 2-4. Measures of Success for 244-AR Vault Stabilization Planning. ..........................2-19

Table 5-1. 244-AR Vault Interim Stabilization Project Risk List..................................... 5-3

Table 6-1. 244-AR Vault Interim Stabilization Project Work Breakdown Structure/Level 1 Logic Crosswalk.................................................................6-4

Table 6-2. 244-AR Vault Interim Stabilization Project, Escalated Costs by Fiscal Year with October 1, 2000, Start Date (\$000).

Table 6-3. 244-AR Vault Interim Stabilization Project, Cost by Work Breakdown Structure, Unescalated (\$000).

Table 6-4. 244-AR Vault Interim Stabilization Project, Full-Time Equivalents By Work Breakdown Structure.

Table 6-5. Escalated Costs by Fiscal Year Including Partial Risk Allowance ( $\$ 000)$. 6-14

Table 6-6. Labor, Materials, and Contracts Costs (unescalated) (\$000). 6-15 


\section{TERMS}

$\mathrm{AB}$

ABU

ALARA

ALARACT

ATP

AWA

BCR

CAM

CASS

CAA

CEIS

CFR

$\mathrm{CHG}$

DACS

DOE

DOE-HQ

DST

Ecology

EIS

EPA

ESH\&Q

FH/FHI

FSAR

FTE

FY

GMS

HAZOP

HPT

IS

ISMS

LFL

LMHC

MYWP

NEPA

NESHAP

NOC

NS\&L

ORP

ORR

OTP

P3

PI

PBS

PHMC authorization basis

acceptance for beneficial use

as low as reasonably achievable

as low as reasonably achievable control technology

acceptance test plan/procedure

advance work authorization

baseline change request

continuous air monitor

Computer-Automated Surveillance System

Clean Air Act

cost-estimating input sheet

Code of Federal Regulations

CH2M HILL Hanford Group

Data Acquisition and Control System

U.S. Department of Energy

U.S. Department of Energy Headquarters

double-shell tank

Washington State Department of Ecology (WDOE)

environmental impact statement

U.S. Environmental Protection Agency

environmental, safety, health, and quality assurance

Fluor Hanford, Inc.

final safety analysis report

full-time equivalent

fiscal year

Gas-Monitoring System

hazard and operability study

health physics technician

interim stabilization

Integrated Safety Management System

lower flammability limit

Lockheed Martin Hanford Corporation

multi-year work plan

National Environmental Policy Act of 1969

National Emission Standards for Hazardous Air Pollutants

notice of construction

Nuclear Safety and Licensing

Office of River Protection

operational readiness review

operational test procedure

Primavera Project Planner, a proprietary scheduling software owned by Primavera Systems, Inc.

performance incentive

project baseline summary

Project Hanford Management Contract 


\section{RPP-5635 REV 0}

PNNL

RA

RCRA

RPP

RL

SA

SEPA

SER

SHMS

SST

TBR

TFFO

TMACS

TRU

TSR

TWO

TWRS

USQ

WAC

WBS

Ecology

WDOH
Pacific Northwest National Laboratory

readiness assessment

Resource Conservation and Recovery Act of 1976

River Protection Project

U.S. Department of Energy, Richland Operations Office safety assessment

State Environmental Policy Act

safety evaluation report

Standard Hydrogen Monitoring System

single-shell tank

technical basis review

Tank Farm Facilities Operations

Tank Monitor and Control System

transuranic (waste)

technical safety requirement

Tank Waste Operations

Tank Waste Remediation System

unreviewed safety question

Washington Administrative Code

work breakdown structure

Washington State Department of Ecology

Washington State Department of Health 


\section{RPP-5635 REV 0}

\subsection{INTRODUCTION}

\subsection{BACKGROUND}

The 244-AR Vault Facility, constructed between 1966 and 1968, was designed to provide lag storage and treatment for the Plutonium-Uranium Extraction Facility (PUREX) tank farm sludges. Tank farm personnel transferred the waste from the 244-AR Vault Facility to B Plant for recovery of cesium and strontium. B Plant personnel then transferred the treatment residuals back to the tank farms for storage of the sludge and liquids. The last process operations, which transferred waste supporting the cesium/strontium recovery mission, occurred in April 1978.

After the final transfer in 1978, the 244-AR facility underwent a cleanout. However, 2,271 L (600 gal) of sludge were left in Tank 004AR from an earlier transfer from Tank 241-AX-104. When the cleanout was completed, the facility was placed in a standby status. (The sludge had been transferred to Tank 004AR to support Pacific Northwest National Laboratory [PNNL] vitrification work. Documentation of waste transfers suggests that a portion of the sludge may have been moved from Tank 004AR to Tank 002AR in preparation for transfer back to the AX Tank Farm; however, quantities of the sludge that were moved to Tank 002AR from that transfer must be estimated.)

Beginning in 1984, the chemical processing contractor, Rockwell Hanford Company, began to modify the 244-AR Vault Facility for a new mission. It was to be used as a transfer, storage, and treatment facility for moving neutralized current acid waste (NCAW) from the aging-waste tank farms (241-AY/AZ) to B Plant. B Plant was to be modified to separate the NCAW into transuranic (TRU) and non-TRU waste streams. The TRU waste stream then was to be returned to the tank farms for transfer to a vitrification facility and then to geologic disposal. The non-TRU waste stream was to be transferred to the Grout Facility for solidification and onsite disposal. Modification of the 244-AR Facility was initiated, but then was suspended before the modifications were completed, as a result of the abandonment of the NCAW mission in 1988. During this period, operations logs and facility records show that the sumps were jetted to the tanks multiple times. Liquids accumulating during this time were assumed to be from intrusions of precipitation and snowmelt through vault covers, roof leaks, floor drains, and drain lines. Some water also came from construction activities during the new mission modifications to the facility.

An air sample taken to support maintenance work in early 1997 recorded a hydrogen concentration of less than $1 \%$ in the dome space of Tank 002AR. Several air samples taken before and since that time, however, have failed to find hydrogen present in any of the tanks.

Three occurrence reports remain open regarding the sump levels in the facility. They document unexplained level changes in the sumps of cell 1 and cell 2 in the 1997 timeframe. These occurrence reports will be closed on approval of the project plan, which will move the tracking of the progress on liquid removal in the 244-AR vault to the new TPA Interim Milestone M-45-11. 


\subsection{TRI-PARTY AGREEMENT MILESTONE M-45-11A DELIVERABLES}

The U. S. Department of Energy (DOE) Office of River Protection Program (ORP) and the Washington State Department of Ecology (Ecology) have agreed on the inclusion of the 244-AR Vault Interim Stabilization effort under the Hanford Federal Facility Agreement and Consent Order (TPA) major milestone series M-45-00, "Complete Closure of all Single-Shell Tanks." The agreement to include the 244-AR Interim Stabilization work within the M-45 milestone series, as M-45-11 and M-45-11A, was approved in TPA Change Number M-45-99-02 dated November 5, 1999.

There are six activities under the M-45-11 milestone scheduled for completion by September 30, 2003:

1. The removal of pumpable liquids from the 244-AR vault tanks

2. The removal of pumpable liquids from the vault itself and its associated sumps

3. Isolation of the $244-\mathrm{AR}$ vault

4. Provisions for the removal of pumpable liquids, which may accumulate in the future

5. Installation of intrusion prevention mechanisms as may be necessary

6. Establishment of periodic liquid level monitoring systems for the detection of accumulating liquids prior to final closure.

Interim Milestone M-45-11A addresses the interim stabilization planning and requires submittal of a 244-AR Vault Interim Stabilization Project Plan, which includes the scope, schedule, and cost of these six activities. The Project Plan must be submitted to Ecology no later than April 30, 2000.

Interim Milestone M-45-11 addresses the actual interim stabilization of the facility. A copy of the Hanford Federal Facility Agreement and Consent Order Change Control Form M-45-99-02, containing TPA Interim Milestones M-45-11 and M-45-11A, is provided in Figure 1-1.

\subsection{PERFORMANCE INCENTIVE ORP3.3.1 DELIVERABLES}

The DOE-ORP established a Performance Incentive (PI) ORP3.3.1 with CH2M HILL Hanford Group, Inc. (CHG), which includes the planning of the 244-AR Interim Stabilization work in fiscal year (FY) 2000.

The Performance Expectation for the 244-AR Vault in PI ORP3.3.1 reads as follows: "Provide a Project Plan (by March 30, 2000) for stabilizing the 244-AR Vault." 
Figure 1-1. Federal Facility Agreement and Consent Order Change Control Form M-45-99-02. (2 Sheets)

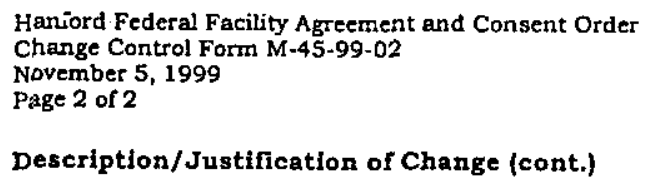

Approval of this Change Form constitutes resolution of Dispute in this matter as noted within DOE's July 12, 1999 correspondence to Ecology (99-EAP-398), its subsequent August 11, 1999 correspondence elevating this dispute to the Parties Inter Agency Management Integration Team (IAMIT) (99-EAP-436), and associated documentation.

Agreement Interim Milestone and Target Date deleted on approval of this M-45-99-02 Change Form are as follows:

\begin{tabular}{|c|c|c|}
\hline$M-32-06$ & COMPLETE 244-AR VAULT INTERIM STATUS TANK ACTIONS & $\begin{array}{l}\text { PRIOR TO } \\
\text { RESTART }\end{array}$ \\
\hline $\mathrm{M}-32-06-\mathrm{TO} 1$ & $\begin{array}{l}\text { COMPLETE AND SUBMIT INTEGRITY ASSESSMENT REPORT AND IDENTIFIED } \\
\text { UPGRADES FOR } 244-A R \text { VAULT INTERIM STATUS TANK SYSTEM (EXCEPT } \\
\text { THAT DST TRANSFER LINES THAT PENETRATE THE 244-AR VAULT WILL } \\
\text { CONTINUE TO BE USED). PROVIDE A SCHEDULE TO ADDRESS ANY } \\
\text { DEFICIENCIES DESCRIBED IN THE REPORT RELATED TO TANK SYSTEM } \\
\text { COMPLIANCE. }\end{array}$ & $\begin{array}{l}\text { PRIOR TO } \\
\text { RESTART }\end{array}$ \\
\hline
\end{tabular}

Agreement Interim Milestones established on approval of this M-45-99-02 Change Form are as follows:

\begin{tabular}{|c|c|c|}
\hline$M-45-11$ & COMPLETE 244-AR VAULT INTERIM STABILIZATION. & $09-30-03$ \\
\hline$M-45-11 A$ & $\begin{array}{l}\text { SUBMIT 244-AR VAULT INTERIM STABILIZATION PROJECT PLAN FOR } \\
\text { ECOLOGY APPROVAL. } \\
\text { INTERIM STABILIZATION ACTIVITY ENDPOINT CRITERIA WILL BE } \\
\text { ESTABLISHED ON APPROVAL OF THE STABILIZATION PROJECT PLAN. AT } \\
\text { MINIMUM THE PLAN SHALL ESTABLISH CRITERIA FOR, AND SCHEDULE } \\
\text { INTERIM STABILIZATION ACTIVITIES INCLUDING: THE REMOVAL OF } \\
\text { PUMPABLE LIQUIDS FROM 244-AR VAULT TANKS; THE REMOVAL OF } \\
\text { PUMPABLE LIQUIDS FROM THE VAULT ITSELF AND ITS ASSOCIATED SUMPS; } \\
\text { ISOLATION OF THE } 244-A R \text { VAULT; PROVISIONS FOR THE REMOVAL OF } \\
\text { PUMPABLE LIQUIDS WHICH MAY ACCUMULATE IN THE FUTURE; } \\
\text { INSTALLATION OF INTRUSION PREVENTION MECHANISMS AS MAY BE } \\
\text { NECESSARY; AND ESTABLISHMENT OF PERIODIC LIQUID LEVEL } \\
\text { MONITORING SYSTEMS FOR THE DETECTION OF ACCUMULATING LIQUIDS } \\
\text { PRIOR TO FINAL CLOSURE. } \\
\text { THE 244-AR VAULT INTERIM STABILIZATION PROJECT PLAN WILL BE } \\
\text { ESTABLISHED AND MANAGED AS A PRIMARY DOCUMENT PURSUANT TO } \\
\text { AGREEMENT ACTION PLAN 9.2. }\end{array}$ & $04-30-00$ \\
\hline
\end{tabular}

Note: The M-45-11 "Complete 244-AR Vault Interim Stabilization" due date has been established prior to finalization of the planning basis for vault stabilization activities. Should new information affect completion of interim stabilization activities, appropriate modifications shall be made by agreement of the Parties pursuant to Agreement Action Plan, Section 12.0.

Reference: 1) Letter, A. Valero, Ecology, to G. Sanders, RL, "Rc: 244-AR Vault System Change Control Request to Delete Tri-Party Agreement (TPA) Milestones M-32-06 and M-32-06-T01," dated August 19, 1999. 
Figure 1-1. Federal Facility Agreement and Consent Order

Change Control Form M-45-99-02. (2 Sheets)

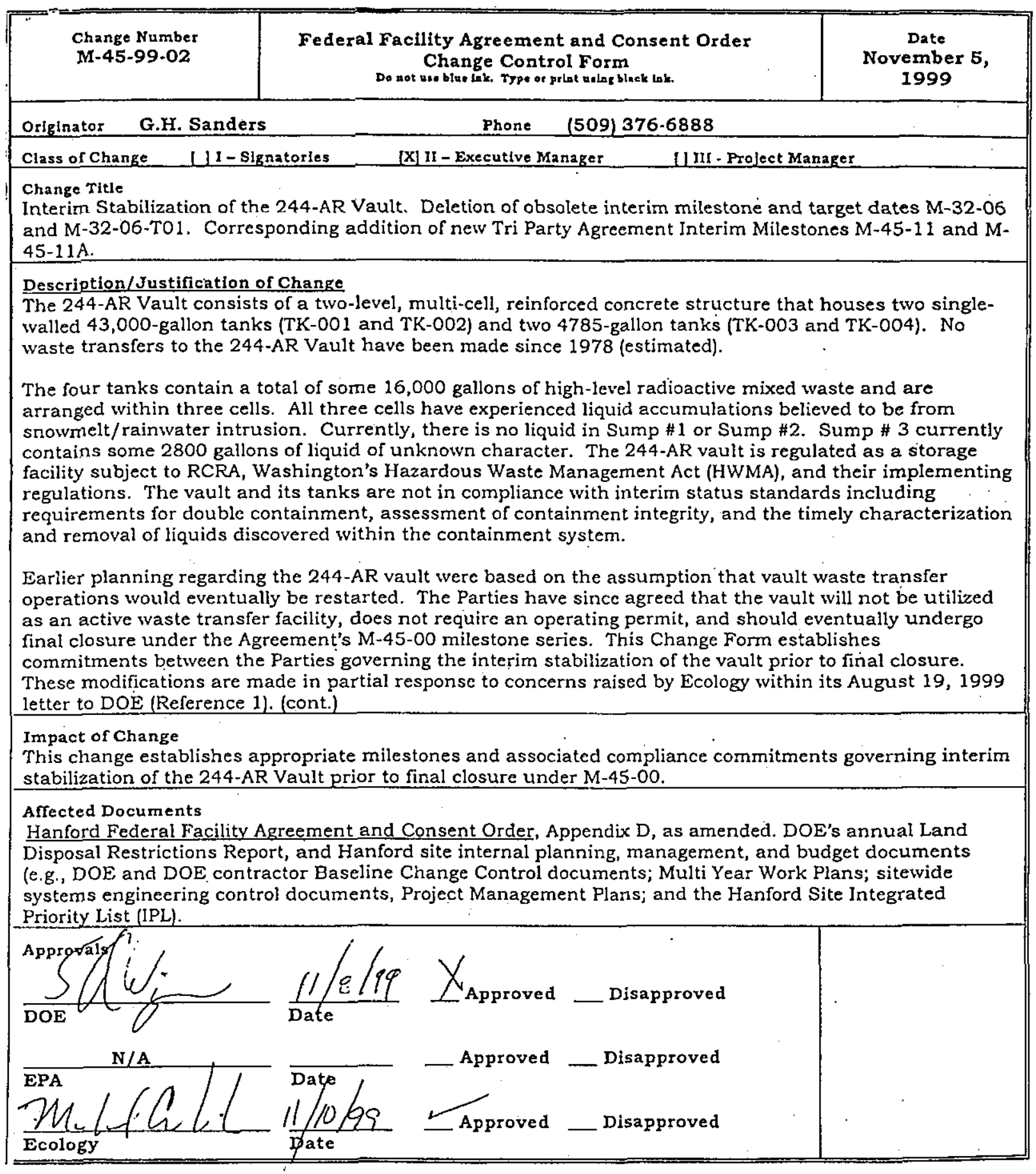




\section{RPP-5635 REV 0}

There are four requirements for the satisfactory completion of the 244-AR Project Plan required by the PI:

1. Address the six items listed in the TPA Milestone M-45-11A

2. Describe the scope of work necessary to stabilize the vault(s) until the facility(s) may be turned over for final disposition and closure

3. Provide a cost estimate for performing the scope of work

4. Provide a schedule for completing the work.

\subsection{OVERALL PLANNING APPROACH AND THE FOCUSED TASK TEAM}

A focused task team was established to develop, evaluate, and document a plan to stabilize the 244-AR Vault Facility. The 244-AR Interim Stabilization Team used a systems engineering, logic-based planning approach. Members of the task team were chosen to represent the major functions within the River Protection Project (RPP), including Operations; Maintenance; Nuclear Safety \& Licensing; Environmental, Safety, Health, and Quality; Engineering; and Process Engineering, as well as support staff. A requirements matrix (see Appendix A) defines the goals and deliverables required to meet the expectations of TPA Milestone M-45-11. Measures of success for the planning phase of the work, addressing TPA Interim Milestone M-45-11A and PI ORP3.3.1, are listed in Table 2-4. The management approach to the project is discussed in Appendix B. A logic network (see Appendix C) was prepared to focus the efforts in a disciplined project approach for planning, scheduling, and costing of activities. Additional details of the project organization appear in Section 7.0. 
RPP-5635 REV 0

This page intentionally left blank. 


\subsection{MISSION ANALYSIS}

The primary mission of the 244-AR Vault Interim Stabilization Project is to remove any remaining pumpable liquids from the three sumps and the four tanks located within the canyon facility. Additional steps will be taken as part of the plan to isolate the facility, prevent further intrusions of precipitation or snowmelt, provide periodic monitoring to detect any future intrusion, and retain the ability to pump accumulated liquids in the future if it is necessary. The work will be planned in FY 2000 with submittal of the project plan to ORP by March 30, 2000. The stabilization work will be scheduled on receipt of funding to support completion by September 30, 2003.

This section addresses the evaluation of the 244-AR vault project mission. It reviews the problem, the options for stabilization, and the path forward. It also establishes the project boundaries and interfaces, addresses the current conditions of the facility, and projects the conditions at completion of stabilization. The mission life cycle is reviewed in this section, which also looks at mission-level requirements, objectives, measures of success, and path forward. A more detailed description of the path forward appears in Sections 3.0, "Technical Strategy," 4.0, "Project Strategy," and 6.0, "Project Baseline."

\subsection{PROBLEM STATEMENT}

Liquid waste remains in the 244-AR Vault Facility though the vault has been taken out of service. The majority of this waste is contained in the process tanks, with some liquid being held in the process cell sumps. The current volume estimates for the liquid levels in the tanks and sumps of the facility are shown in Figure 2-1. Although the review of transfer records, facility logs, and personnel interviews indicates that the majority of the liquid present is water from precipitation or snowmelt that has leaked into the facility over the years since it was taken out of service, some process waste is still contained within the tanks. TPA Interim Milestone M-45-11 requires that pumpable liquids be removed and the facility be isolated and that steps be taken to prevent intrusions from future precipitation and snowmelt. Also required is that the stabilized facility be monitored and provision be made for the removal of liquid from the facility should further intrusion occur. 
Figure 2-1. Current Tank and Sump Liquid Levels.

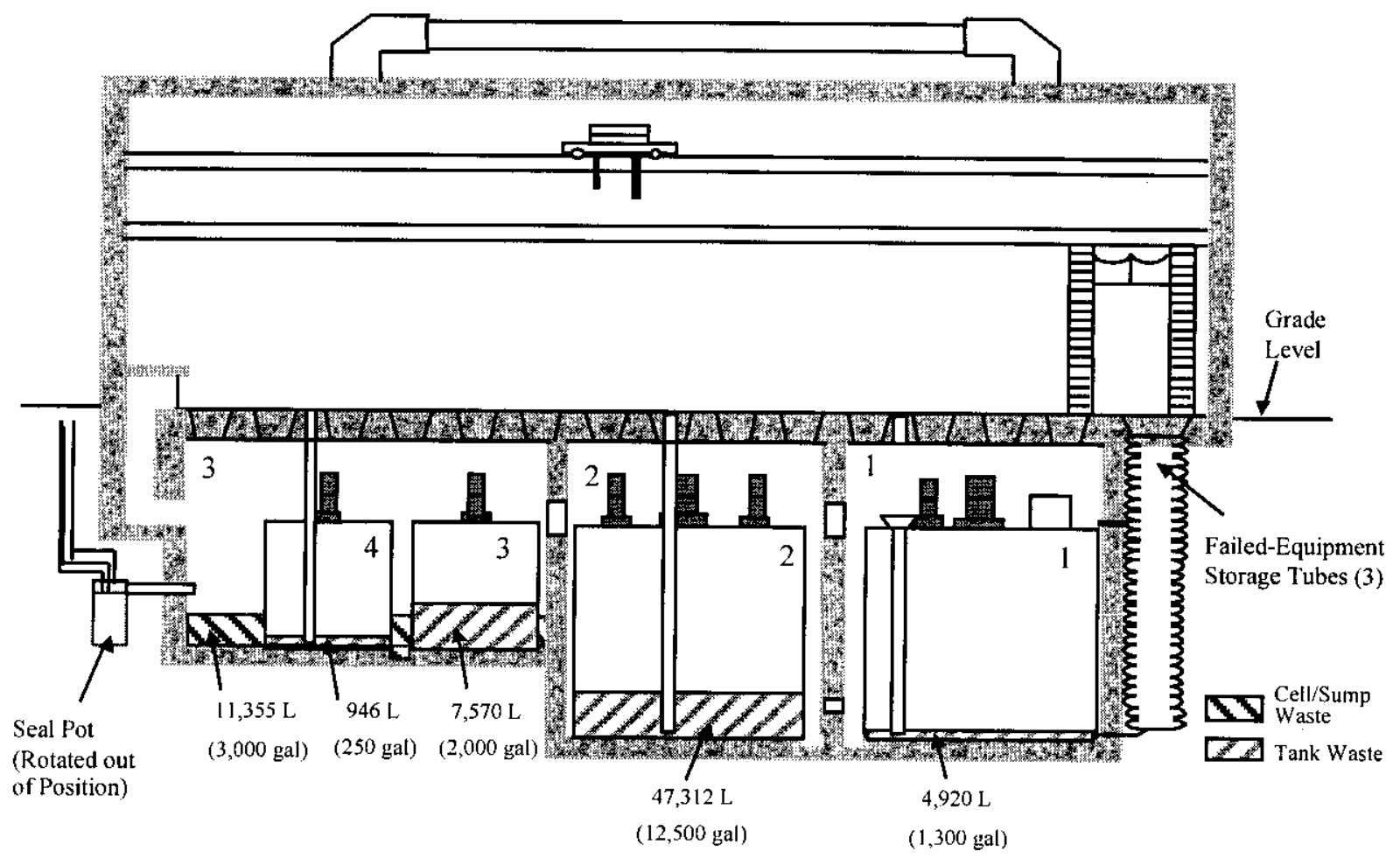

\section{$2.2 \quad$ PROJECT OBJECTIVE}

The objective of the 244-AR Vault Interim Stabilization Project is to remove the pumpable liquids from the facility and prevent any future accumulation of liquids in the 244-AR vault. The goal is to remove the liquids in a safe, efficient and timely manner that would not affect the subsequent deactivation of the facility.

\subsection{PROJECT TIMING}

The recently adopted TPA Interim Milestone M-45-11A requires submittal of the project plan for the interim stabilization of the 244-AR Vault Facility to Ecology by April 30, 2000. The PI ORP3.3.1 requires that the project plan be submitted to ORP by March 30, 2000. This document serves to meet these deliverables. Interim Milestone M-45-11 requires that interim stabilization work be completed before September 30, 2003. Because the physical work is not scheduled to be performed during this fiscal year and is not yet funded, the actual project start date has not been determined. For the purpose of cost estimating and schedule logic, the plan is modeled with a start date of October 1,2000. This project plan describes the scope, schedule, and cost of the proposed work. The project will be added to the integrated RPP schedule when a start date is confirmed and funding is identified. Project activity interferences for both workspaces and the availability of resources must be evaluated at the time when the project is funded and added to the RPP schedule. 
RPP-5635 REV 0

\subsection{PROJECT BOUNDARIES AND INTERFACES}

Figure 2-2 shows the 244-AR canyon stabilization activity boundaries and interfaces for removal of pumpable liquids and facility isolation. The main block in the center of the figure lists the initial status and the desired end status for the facility, along with the internal interfaces. Other interfaces are shown outside the large block. The following sections describe the external and programmatic interfaces, as well as the physical, internal, and other RPP Project interfaces depicted in the figure.

\subsubsection{External Interfaces}

- Washington State Department of Ecology (Ecology). Ecology has regulatory authority over all facilities storing dangerous waste under the Resource Conservation and Recovery Act of 1976 (RCRA). Operational changes that affect the RCRA permit conditions must be approved by Ecology. Additionally, Ecology has regulatory authority over non-radioactive air emissions.

- Washington State Department of Health (WDOH). WDOH has regulatory authority over radioactive air emissions from all facilities.

- U.S. Environmental Protection Agency (EPA). EPA has federal authority over radioactive air emissions.

\subsubsection{Programmatic Interfaces}

- U.S. Department of Energy Headquarters (DOE-HQ). DOE-HQ provides funding and overall direction to ORP.

- U.S. Department of Energy Office of River Protection (ORP). The ORP manages all activity within the RPP.

\subsubsection{Potential Effects on Other River Protection Project Programs}

The total liquid accumulated inside the $244-\mathrm{AR}$ vault is approximately $72,105 \mathrm{~L}(19,050 \mathrm{gal})$. At anticipated transfer system flow rates, this liquid will be transferred to a double-shell tank (DST) in less than one day. A liquid transfer of this duration can be scheduled so as not to interfere with other DST activities.

All of the pre-transfer activities, including liquid consolidation into one tank, can be completed independently of tank farm programs. Although competing DST resources will have to be scheduled to avoid conflicts, no negative effects are anticipated. 


\section{RPP-5635 REV 0}

Figure 2-2. 244-AR Canyon Stabilization Activity Boundaries and Interfaces.

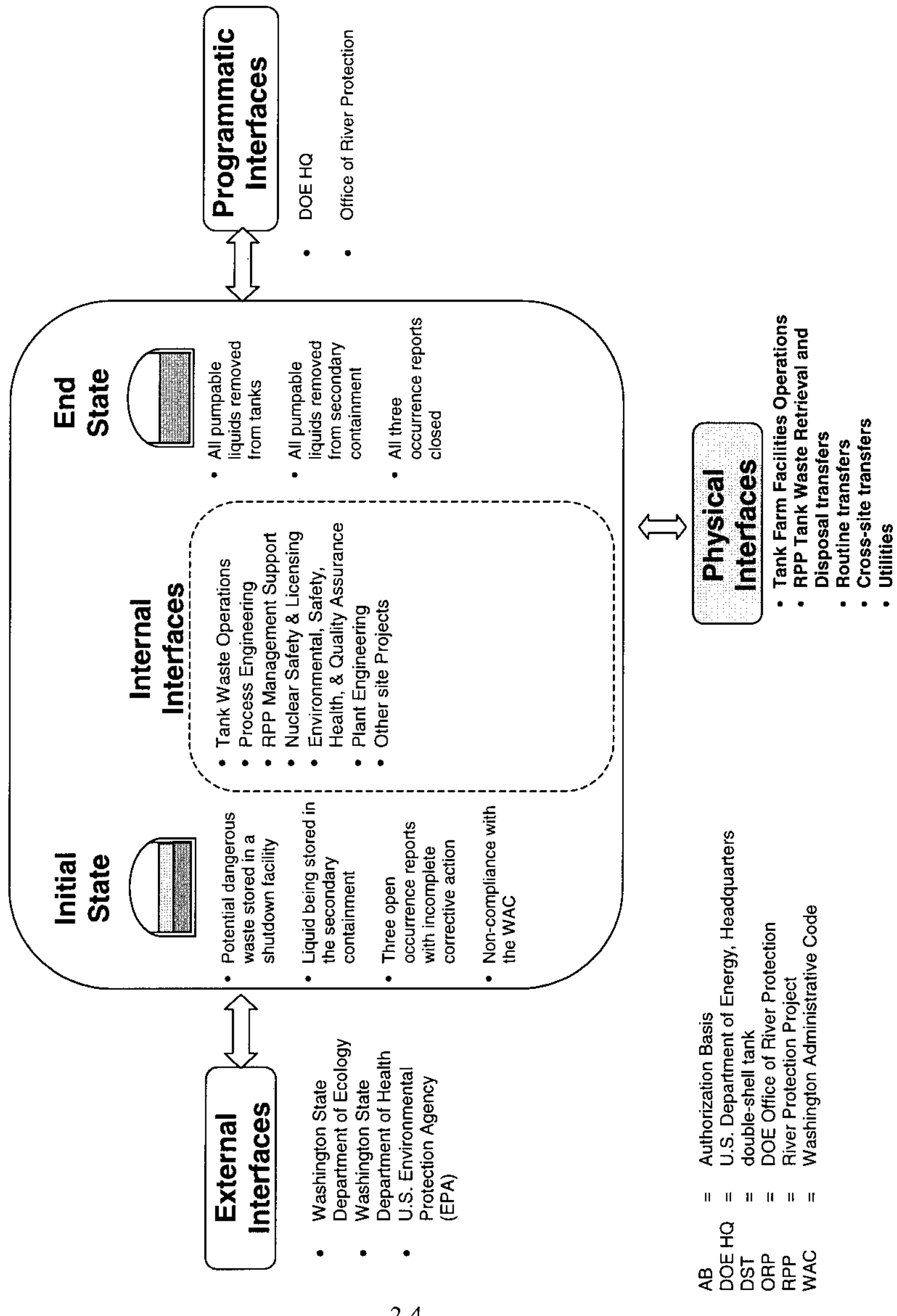


A benefit of the stabilization activities should be reduced surveillance cost for the facility. With the liquid removed, the purge on Tank 002AR should no longer be required. In addition, with the vault isolated, intrusion detection requirements should be limited to the sumps, and the frequency of monitoring should be reduced.

\subsubsection{Facility Boundaries}

The 244-AR Vault Facility includes the 244-AR vault and all surrounding structures that support facility operation. The facility boundary is shown in Figure 2-3.

\subsubsection{Physical Interfaces}

Tank Farms Facility Operations (TFFO). The management of tank waste includes operation, surveillance and maintenance of the tanks, facilities, and associated infrastructure. The stabilization activities will modify the 244-AR Facility and use the DST transfer system for liquid removal. Close coordination of all work supporting the stabilization activities and TFFO will be required. Liquid transfers from the 244-AR Facility will not change the basic chemical composition of the waste in the receiving DST.

RPP Tank Waste Retrieval and Disposal Transfers. To reduce the potential for additional contamination of the environment, ORP plans to transfer the waste from the single-shell tanks (SST) to the DST system and then transfer the waste to privately owned and operated waste immobilization facilities. This approach is referred to as RPP Tank Waste Retrieval and Disposal. The 244-AR interim stabilization activities will not result in any significant adverse effects on the final retrieval of waste from the DSTs.

Transfers. The 244-AR interim stabilization activities will use a temporary transfer system inside the facility but will require installation of a new transfer line outside the facility that ties into the DST transfer system at diversion box 241-AR-151. This tie-in and subsequent liquid transfer will be scheduled so that it does not interfere with routine DST transfers.

Utilities. Utilities include the electrical power required to operate transfer pumps, ventilation, lighting, and instrumentation, as well as water for flushing and compressed air for transfer line purge. The 244-AR interim stabilization activities will need to coordinate any utility upgrades with TFFO. The flush water will be supplied by a portable tanker, as the facility water supply is isolated.

\subsubsection{Internal Interfaces}

- Nuclear Safety and Licensing (NS\&L). The NS\&L organization is responsible for the preparation and maintenance of RPP nuclear safety authorization basis (AB) documentation. NS\&L also has the responsibility for resolving the formal safety issues. NS\&L is responsible for developing the licensing strategy and AB modification to allow the stabilization activities to proceed. 
Figure 2-3. 244-AR Vault Facility Boundary.

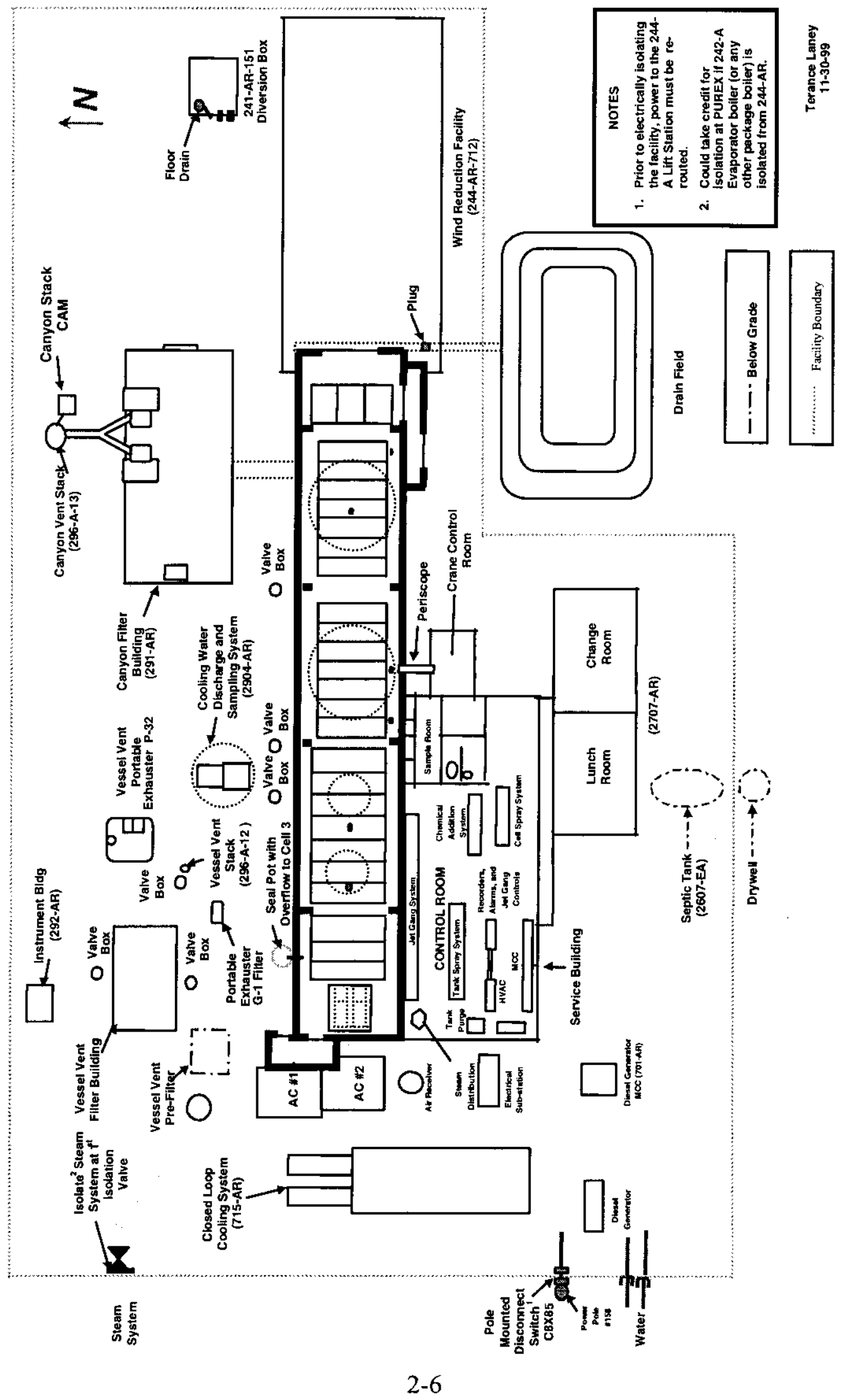




\section{RPP-5635 REV 0}

- Plant Engineering. The Plant Engineering organization is responsible for designing the transfer system and providing test acceptance criteria

- Tank Waste Operations (TWO). The TWO group is responsible for carrying out the day-to-day operational activities, maintenance, and surveillance monitoring of the RPP tank farm system. Routine tank farm surveillances are performed to existing procedures. The TWO manages all tank waste, including the liquid stored in the 244-AR Facility. It will ensure that the DST transfer system remains in operating order and will maintain 244-AR surveillance during the stabilization activities. On concluding the stabilization activities, TWO will retain responsibility for the monitoring of 244-AR until turnover.

- RPP Environmental, Safety, Health, and Quality Assurance (ESH\&Q). The RPP ESH\&Q organization is responsible for ensuring that proper permits and notices of construction (NOC) are written and transmitted through the ORP to the proper state and regulatory agencies. The organization is also responsible for informing the 244-AR interim stabilization project management well in advance of startup of any permit conditions that must be incorporated into their procedures. It also will review, as necessary, planned work evolutions and provide any required job-specific safety and quality assurance plans.

- RPP Management. RPP management is responsible for establishing priorities and providing management direction and oversight to 244-AR interim stabilization.

- Process Engineering. The Process Engineering organization is responsible for determining liquid composition and assessing waste compatibility as necessary to ensure that the basic chemical composition of the waste meets the DST criteria.

\subsubsection{Other Site Projects}

Several construction projects are scheduled in the tank farms during the time scheduled for 244-AR interim stabilization. Because the start date for 244-AR interim stabilization has not yet been set, those interfaces have not been reviewed. Although the project plan does not anticipate specific tank farm interfaces, competition for resources and equipment needs to be coordinated once the project start date is identified.

\subsubsection{Inputs and Outputs}

- Before liquid is removed from the facility, the 244-AR stabilization activities will test for $\mathrm{pH}$ levels and consolidate all pumpable liquid from the sumps and tanks into one tank. The tank will be sampled and chemically adjusted to meet DST acceptance criteria. The liquid then will be transferred from the 244-AR Facility to a DST.

The stabilization activity requires the following:

- Electrical power

- Temporary water supply 
- Liquid level indication

- Chemical adjustment chemicals

- Compressed air.

Stabilization activities will produce the following:

- Chemically-adjusted pumpable liquid transferred to a DST

- Small volumes of solid waste

- Data to satisfy TPA Interim Milestone M-45-11

- Documentation on physical and health physics conditions inside the facility.

\subsection{BEGINNING STATES AND ENDING STATES}

Process operations in the 244-AR Vault Facility last were performed in 1978. Internal steam jetting of the accumulated liquids from the sumps to the tanks and from tank to tank continued until 1992. Facility ventilation was shut down in 1993. Service steam and water also have been isolated from the facility. Without steam, water, or ventilation, the installed steam jetting system cannot be operated to remove the liquids from the sumps or the tanks. Since facility shutdown, overflow from the seal pot and intrusion from precipitation and snowmelt have continued to accumulate in the 244-AR vault. A portable exhauster was installed on the vessel vent system in 1997 and operated briefly in an attempt to air jet the liquids. The exhauster was left in place when funding for the effort ended. Liquids are known to be present in all four of the tanks and in sump three.

\subsubsection{Facility Configuration}

The canyon building is a reinforced concrete structure with $0.457 \mathrm{~m}\left(1 \frac{1}{2} \mathrm{ft}\right)$-thick walls. On the inside, the canyon building measures $28.651 \mathrm{~m}(94 \mathrm{ft})$ by $5.486 \mathrm{~m}(18 \mathrm{ft})$ by $10.973 \mathrm{~m} \mathrm{(36 \textrm {ft } )}$ high above the process cell cover blocks. Cover blocks $1.524 \mathrm{~m}(5 \mathrm{ft})$ thick with recessed lifting bails separate the process cells (housing the process vessels and associated equipment) from the canyon deck. The above-deck-level canyon equipment includes one 18.14 metric ton ( 20 ton) and two 0.907 metric ton ( 1 ton) hoists located on a remotely controlled overhead bridge crane. Other equipment includes an industrial wall periscope, a closed-circuit television system, and radiation monitoring equipment. The general configuration of the facility is shown in Figures 2-4 and 2-5.

Three process cells and three failed-equipment storage tubes are located below the canyon deck level and are accessible by the removal of the concrete cover blocks. Each of the three process cells contains an $0.457 \mathrm{~m}(1 \mathrm{l} / 2 \mathrm{ft})$ deep sump and an intercell overflow opening that also serves as a ventilation path between the cells. Cells 1 and 2 are of identical dimensions, $6.401 \mathrm{~m}(21 \mathrm{ft})$ square by $9.982 \mathrm{~m}(32.75 \mathrm{ft})$ deep, measured from the bottom of the cover blocks to the top of the tank pad. Cells 1 and 2 contain Tanks 001AR and 002AR, respectively. Tanks 001AR and

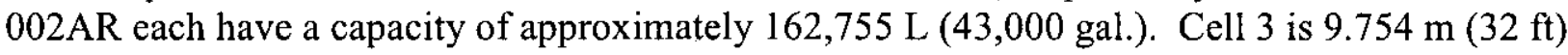
by $3.658 \mathrm{~m}(12 \mathrm{ft})$ by $6.401 \mathrm{~m}(21 \mathrm{ft})$ deep. The cell walls are $0.610 \mathrm{~m}(2 \mathrm{ft})$ thick. 


\section{RPP-5635 REV 0}

Figure 2-4. 244-AR Construction (General Layout).

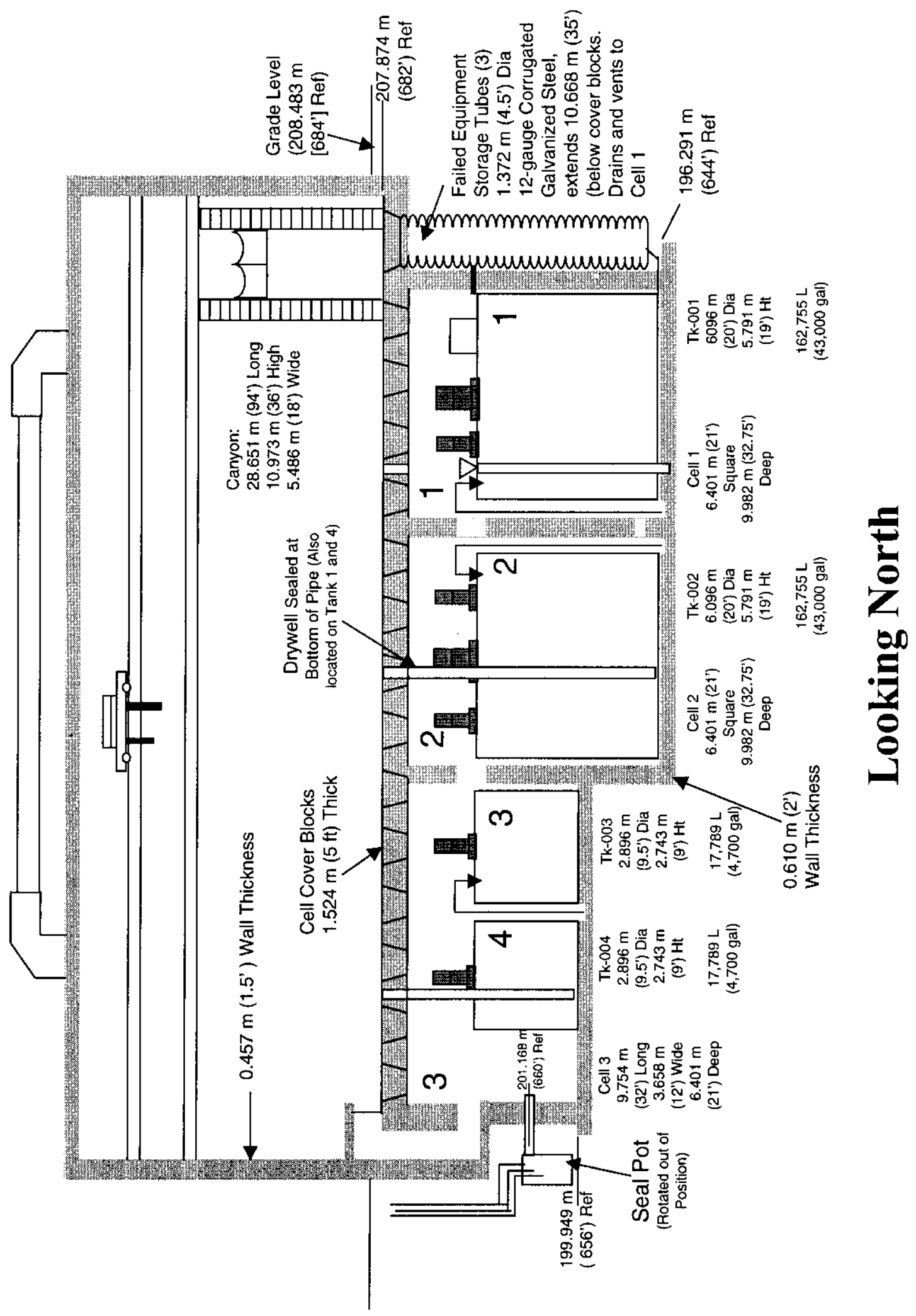




\section{RPP-5635 REV 0}

Figure 2-5. 244-AR Construction (General Layout).

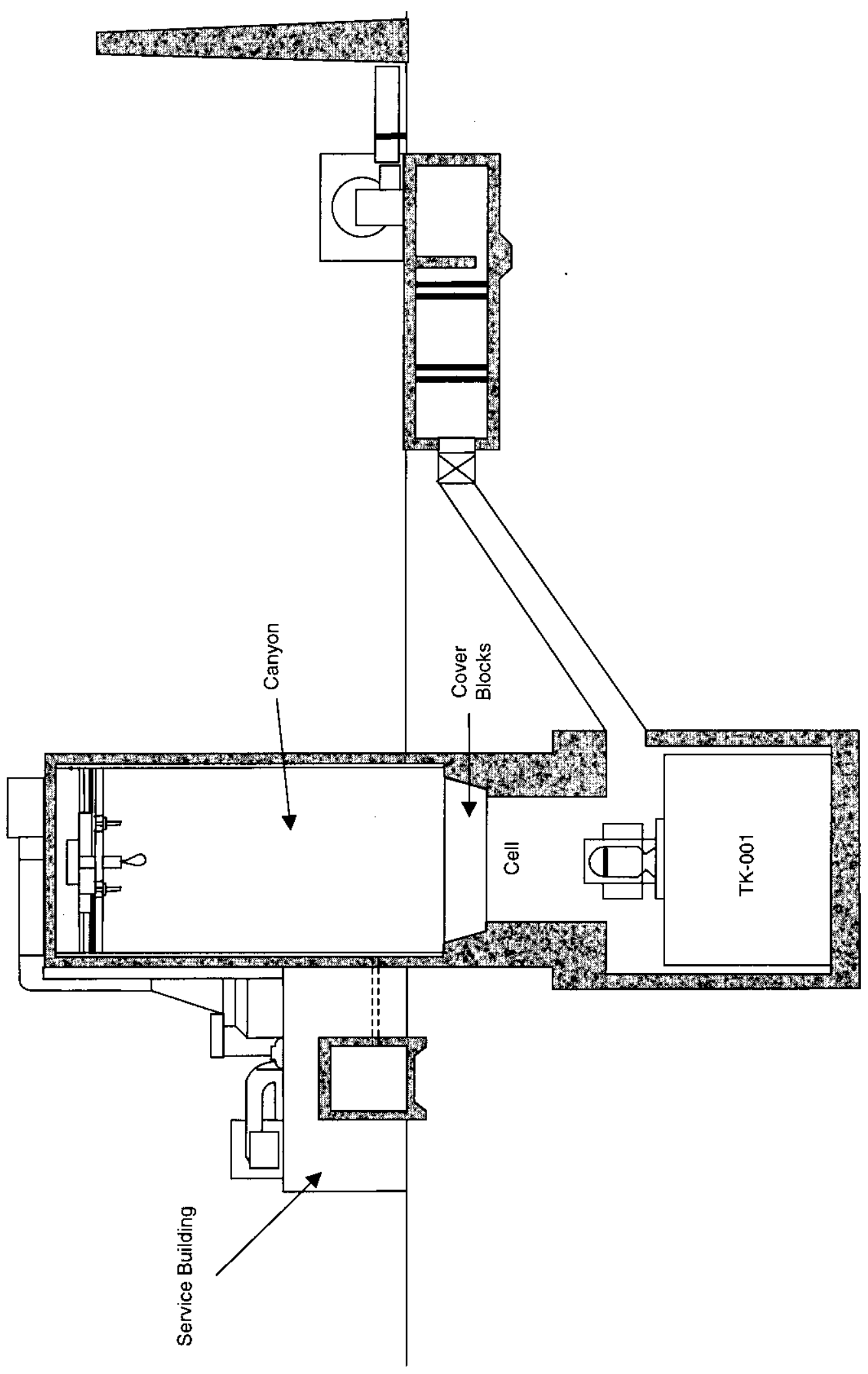


Cell 3 contains Tanks 003AR and 004AR. Each tank has a capacity of approximately 17,789.5 L $(4,700 \mathrm{gal}$.). Each of the failed-equipment storage tubes is covered with a cover block $0.610 \mathrm{~m}$ $(2 \mathrm{ft})$ thick. The tubes vent and drain to cell 1 . Because cell 1 does not contain any liquids, the tubes are assumed to be dry.

The only systems that are operational are electrical power distribution and level detection. A portable air compressor serves as the air source for level-detection instruments and supplies purge air to Tank 002AR. None of the liquid removal or support equipment has been maintained, and no steam is available for the steam jetting system. The precise configuration of the transfer jumpers and process blanks below the cover blocks is unknown and will be determined by a camera survey during the design phase. The camera survey will also assist in determining access areas on the top of each process tank.

\subsubsection{Current Tank/Sump Liquid Conditions}

The 244-AR vault consists of four tanks, housed in three cells: Tank 001AR in cell 1, Tank 002AR in cell 2, and Tanks 003AR and 004AR in cell 3. Each cell contains its own sump. The last known transfer of waste into or from the vault was 1978. It then was cleaned out, with the exception of 2,270 L ( 600 gal) of sludge from 104-AX. Numerous facility log entries reflect steam jetting of the sumps into the tanks during the period from 1978 to 1992. The origin of the liquid that had accumulated in the sumps is believed to be primarily intrusions of water from various sources. Included in the sources are precipitation and snowmelt, which leaked through facility pit covers or roofs and entered the cell either directly or through a drain routed to the cells. Construction water generated as the facility was being upgraded (1984-1988) also drained to the cell sumps. Included as a possible additional source was a water line break that flooded the area around the vault in early 1997. It should be noted that condensate and drainage from facility support structures and pits drain to the sumps and tanks by design. Jetting the sumps to remove the liquids was a common operation. Table 2-1 summarizes the volumes of liquid estimated to remain in the 244-AR vault. The liquid conditions in each of the three sumps and four tanks are discussed briefly below.

Table 2-1. Summary of Volumes of Material Estimated to Remain in 244-AR Vault.

\begin{tabular}{|c|c|c|}
\hline Location & Volume, Liters (gallons) & Trend \\
\hline Cell 1 & 0 & Stable \\
\hline Cell 2 & 0 & Stable \\
\hline Cell 3 & $11,355(3,000)$ & Stable \\
\hline Tank 1 & $4,920(1,300)$ & Stable \\
\hline Tank 2 & $47,312(12,500)$ & Stable \\
\hline Tank 3 & $7,570(2,000)$ & Stable \\
\hline Tank 4 & $946(250)$ & Stable \\
\hline
\end{tabular}

The sump in cell 1 contains a small quantity of liquid that is required for the operation of the instrumentation. Sump 1 does not contain any pumpable liquid. However, in the past, water 
levels in the cell were recorded at levels higher than the drain line openings from the failed-equipment storage tubes located adjacent to the cell. There are records showing that the cell 1 sump was jetted into Tank 001AR a number of times in 1985 and 1986.

The sump in cell 2 also contains a small amount of liquid but not in quantities sufficient to be pumpable. Testing of the cooling water coils in Tank 002AR in 1985 resulted in water in the cell 2 sump. Several transfers were made from the cell 2 sump to Tank 002AR during 1985 and 1986.

The sump in cell 3 contains approximately 11,355 L (3,000 gal) of liquid. The liquid may have been from the water line break in 1997 and/or seal pot overflow resulting from drainage into the seal pot of precipitation and snowmelt intrusions.

The contents of Tank 001AR were pumped to Tank 241-AY-101 in 1978. Water from leak testing in 002AR was added in 1978. The cell 1 sump has been jetted into the tank several times.

Waste from Tank 002AR was sent to Tank 241-AY-101 in 1978. In 1985, waste was moved from tank 004AR to 002AR. In addition, the cell 2 sump was jetted to the tank. Approximately $3785 \mathrm{~L}$ (1,000 gal) of flush water were added to the tank in 1985 when the chemical addition system was flushed.

The contents of Tank 003AR were pumped to Tank 241-AY-101 in 1978. Several additions to the tank have been made from the cell 3 sump since that time.

Tank 004AR received approximately $2,270 \mathrm{~L}$ ( $600 \mathrm{gal})$ of neutralized current acid waste (NCAW) from Tank 241-AX-104 that was being held for experiments at Battelle. The majority of this waste was eventually transferred to 002AR in 1985. No additional transfers of liquid have been found to Tank 004AR.

The best estimate of the contents of the tanks and sumps is summarized in Table 2-2.

Table 2-2. Best Estimate of Material in the Tanks of 244-AR Vault.

\begin{tabular}{|l|c|l|}
\hline \multicolumn{1}{|c|}{ Tank } & Volume, $\mathbf{L}(\mathrm{gal})$ & \multicolumn{1}{c|}{ Type of Waste } \\
\hline 001AR & $4,920(1,300)$ & $378 \mathrm{~L}(100 \mathrm{gal})$ of sludge; the remainder contaminated water \\
\hline 002AR & $47,312(12,500)$ & $\begin{array}{l}\text { Contains 7,570 L }(2,000 \text { gal }) \text { of supernatant, 1514 L (400 gal) of } \\
\text { sludge, with the remainder being water. }\end{array}$ \\
\hline 003AR & $7,570(2,000)$ & Contaminated water with 189 L (50 gal) of sludge \\
\hline Cell 3 Sump & $11,355(3,000)$ & Contaminated water \\
\hline 004AR & $946(250)$ & Heel of supernatant with 189 L (50 gal) of sludge. \\
\hline Total Waste & $72,105(19,050)$ & Mostly contaminated water \\
\hline
\end{tabular}

Without the benefit of waste samples, the type of waste in the tanks can only be estimated. A study of the waste streams at the Hanford Site produced what is called Hanford Defined Wastes (LA-UR-96-858). One of these streams is the best estimate of waste for the 244-AR Facility. The composition of sludge and supernatant present in the AR Facility definition is given in Table 2-3. 
Table 2-3. Hanford Defined Waste Stream for 244-AR Vault.

\begin{tabular}{|c|c|c|}
\hline Analyte & Sludge, $\mathrm{mol} / \mathrm{L}$ & Supernatant, $\mathrm{mol} / \mathrm{L}$ \\
\hline $\mathrm{Na}$ & 5.6 & 1.35 \\
\hline $\mathrm{Al}$ & 0.071 & 0.022 \\
\hline $\mathrm{Fe}$ (total) & 1.30 & 0.002 \\
\hline $\mathrm{Cr}$ & 0.0142 & 0.017 \\
\hline $\mathrm{Bi}$ & $9.6 \mathrm{E}-6$ & $1.2 \mathrm{E}-5$ \\
\hline $\mathrm{Hg}$ & $3 \mathrm{E}-7$ & $3.6 \mathrm{E}-7$ \\
\hline $\mathrm{Zr}$ & $3.4 \mathrm{E}-7$ & $4.1 \mathrm{E}-7$ \\
\hline $\mathrm{Pb}$ & $4.9 \mathrm{E}-5$ & $6 \mathrm{E}-5$ \\
\hline $\mathrm{Ni}$ & 0.14 & 0.0018 \\
\hline $\mathrm{Mn}$ & 0.0022 & 0.0027 \\
\hline $\mathrm{Ca}$ & 0.11 & 0.009 \\
\hline $\mathrm{K}$ & 0.006 & 0.0074 \\
\hline TOC wt $\% \mathrm{C}$ & 0 & 0 \\
\hline Free $\mathrm{OH}$ & 0.054 & 0.064 \\
\hline $\mathrm{NO}_{3}$ & $4.3 \mathrm{E}-9$ & 0.32 \\
\hline $\mathrm{NO}_{2}$ & 0.64 & 0.45 \\
\hline $\mathrm{CO}_{3}$ & 0.22 & 0.15 \\
\hline PO4 & 0.019 & 0.023 \\
\hline $\mathrm{SO} 4$ & 0.068 & 0.08 \\
\hline $\mathrm{Si}$ & 2.27 & 0.034 \\
\hline$F$ & 0.00033 & 0.00039 \\
\hline $\mathrm{Cl}$ & 0.015 & 0.018 \\
\hline $\mathrm{NH} 3$ & 0.19 & 0.015 \\
\hline Density & 1.3 & 1.05 \\
\hline $\mathrm{Wt} \% \mathrm{H} 2 \mathrm{O}$ & 69.2 & 90.7 \\
\hline $\mathrm{Pu}-239(\mathrm{Ci} / \mathrm{L})$ & $9.5 \mathrm{E}-03$ & $3 \mathrm{E}-02$ \\
\hline $\mathrm{U}-238(\mathrm{Ci} / \mathrm{L})$ & $1.9 \mathrm{E}-07$ & $2.4 \mathrm{E}-07$ \\
\hline $\mathrm{Cs}-137(\mathrm{Ci} / \mathrm{L})$ & 0.23 & 0.28 \\
\hline $\mathrm{Sr}-90(\mathrm{Ci} / \mathrm{L})$ & 11.8 & 0.034 \\
\hline
\end{tabular}

The quantities of phosphate and aluminum noted are relatively low. These are the two chemicals that are implicated in past pumping difficulties. Problems due to plugging or gelling are not anticipated during the transfer of the liquids. 


\subsubsection{Liquid Conditions Through Interim Stabilization}

Plans are to consolidate all waste into one tank before transferring it from the facility. Tanks 001AR and 002AR are both large enough to hold the estimated liquids. Each sump and tank containing pumpable liquid will be pumped directly into the consolidation tank. The liquid in cell 3 sump will be first, to bring all liquids into the primary containment.

Most of the liquid to be transferred is expected to be contaminated water. The tanks and cell 3 will be $\mathrm{pH}$ tested before consolidation to verify concentrations. The only waste anticipated is the $2,270 \mathrm{~L}$ ( $600 \mathrm{gal}$ ) of NCAW previously pumped to Tank 004-AR. Most of that material now resides in Tank 002AR, which contains a total of $47,000 \mathrm{~L}(12,500 \mathrm{gal})$. Thus the NCAW has already been diluted by a factor of 20 . Additional water will only further dilute this waste.

Because of the dilution of the NCAW that has already occurred and the balance of content being the consistency of contaminated water, it is assumed that the liquids can be mixed in any order and without sampling within the cells in 244-AR vault. No chemical reactions or enthalpy effects will occur that will pose a hazard, because of the high water content of the waste that is expected. The order in which transfers will occur will be determined during the procedure development stage of this project.

The pumping scheme will focus on removing only pumpable liquid with no attempt to remove any sludges or settled solids from the tanks. The tanks will not be flushed to remove any additional dangerous waste residue. Heels will remain in the tanks because of the limitations inherent in pumping from flat-bottomed tanks. There is no plan to remove liquid from sumps in cell 1 and cell 2 or from the failed-equipment storage tubes, since pumpable liquid levels are not present in these locations.

Once the waste has been consolidated into one tank, the contents of that tank will be sampled and analyzed for compatibility in accordance with the "Data Quality Objectives for Tank Farms Waste Compatibility Program HNF-SD-WM-DQO-001" before they are transferred from the facility. Plans are to use the new pumping manifold for sampling, and the assumption is that multiple samples will be needed. A current assumption is that the waste will be transferred to Tank 241-AY-102. If this is the tank of choice, then additional samples may be needed to comply with the feed requirements for subsequent vitrification. It is assumed that the waste will be compatible with the DST waste requirements or can be made compatible by chemical adjustment. Current plans call for chemical addition to be made during transfer although that will be determined as design is finalized.

\subsubsection{Stabilized Facility Configuration}

The 244-AR Facility will be isolated and all pumpable liquids removed from the sumps and tanks. The facility will be physically disconnected from all transfer and liquid support systems. All known intrusion pathways for precipitation and snowmelt will be corrected. Periodic sump level monitoring will be in place to detect any future intrusion into the vault. The transfer system will be flushed and left in place should any liquid accumulation require removal in the future. 


\subsection{MISSION LIFE CYCLE}

The mission life cycle of the 244-AR Vault Interim Stabilization Project began with the planning and conceptual design of the project in FY 2000. The phases of the 244-AR Vault Interim Stabilization Project are shown in Figure 2-6.

Figure 2-6. Project Execution and Engineering Management Planning.

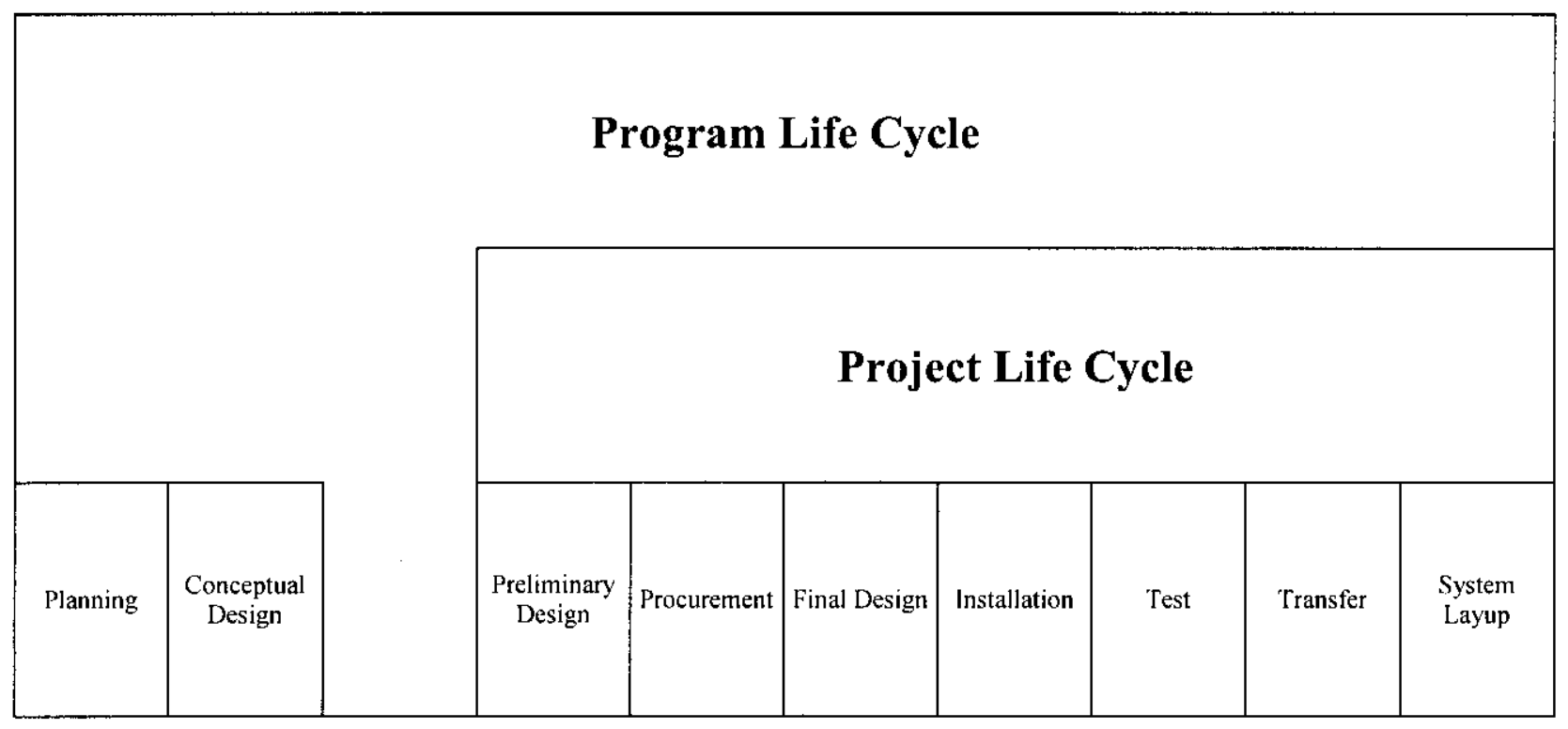

\subsubsection{Program Planning}

A significant effort has been, and is being, spent on the program planning for vault stabilization. A dedicated task team was assembled and charged with completing the planning of the project mission. A path forward workshop was held in December 1999. At this session, a recommended path forward was identified that has been the basis for subsequent program planning. The task team has prepared this detailed project plan while simultaneously performing all early start activities.

\subsubsection{Conceptual Design}

In the early stages of the planning phase of the program, various ideas were considered for solving the stabilization issues at the 244-AR Facility. These ideas were developed into pre-conceptual designs. Although these ideas considered the ultimate deactivation of the facility, the program goal was the near-term stabilization of the 244-AR vault as defined in Section 2.1 above. To determine the best technique for stabilization, ideas were developed and evaluated against the alternatives for accessing the liquids in the vaults and the pumping method to be used. This plan is based on the results of that evaluation. 


\subsubsection{Preliminary Design}

During the preliminary design phase of the program, the design team will develop the conceptual design into a more detailed concept for process flow, pumping configuration and installation, equipment requirements, and infrastructure and will prepare preliminary drawings. Preliminary design and calculations will be prepared and evaluated. A design review will be performed to ensure that all aspects of the design and all equipment requirements are properly evaluated. To facilitate the assembly and testing of the equipment, procurement will begin once the preliminary design has been evaluated. This decision will increase the cost risk but reduce the schedule risk in equipment configuration and assembly. To this end, equipment procurement and component fabrication will begin on completion of preliminary design, using the development control process described in HNF-IP-0842, Vol IV, Section 4.27.

\subsubsection{Procurement}

Procurement will include the contracting of services to support the entry into and preparation of the 244-AR Facility. Commercially available equipment will be used to install commercially available pumps in Tanks 001AR, 002AR, 003AR, and 004AR, and in sump 3. Provisions will be made to enable future pump installation in sumps 1 and 2 .

\subsubsection{Final Design}

In the final design phase, the detailed design will be completed and final design drawings issued. During this phase, the analysis to support the final design also will be completed. Final design will incorporate any changes resulting from set-up and testing or vault mock-up work. A formal final design review will occur at the end of this phase.

\subsubsection{Installation}

This phase of the project will prepare the 244-AR Vault Facility for the installation of the fabricated and pre-tested pumping assembly. Installation and testing will include a common manifold as well as the pump legs for the tanks and sumps that contain liquid. Provision for future connection will be made for those sumps that do not currently contain liquid. The transfer piping required to connect the vault to the DST system also will be installed. Transfer lines outside the 244-AR vault will be encased and underground as much as possible. Lines located inside of the vault will be single-wall lines. Included in the installation process are all of the instrumentation, power, and other utility routings associated with the system. Connections for temporary services such as flush water, air, and portable exhausters will be located outside the vault.

\subsubsection{Transfer}

In this phase of the project, the pumpable liquids will be transferred to a consolidation tank and sampled for compatibility with the DST waste. The waste then will be transferred from the consolidation tank inside the 244-AR Facility to an approved DST through the 241-AR-151 
diversion box. Although the plan routes the transfer to Tank $241-\mathrm{AY}-102$ by way of the $02 \mathrm{D}$ pit, the final acceptable DST will be determined during preliminary design.

\subsubsection{Isolation}

This scope of the work within the project will isolate the facility from any lines that could transport liquids to the vault. Isolation will include the process lines, such as water and steam, as well as the waste transfer lines having an interface external to the 244-AR Vault Facility.

\subsubsection{Intrusion Prevention}

Much of the liquid contained in the vault results from the intrusion of precipitation and snowmelt. This phase of the project will close off those paths of intrusion. Known paths for these intrusions include roof leaks, drains to the facility, and leakage into those vaults that drain to the sumps.

\subsubsection{System Layup}

Following the completion of the transfers, the pumping system will be flushed, isolated from the DST system at the 241-AR-151 diversion box, and placed in a position to preserve its integrity for future use, if required. Temporary services and equipment such as the water truck, air compressor, or portable exhauster will be disconnected and released for use elsewhere. Remaining liquid-detection or level monitoring equipment will remain under Tank Farm Operations for long-term operation.

\subsection{MISSION-LEVEL REQUIREMENTS}

The mission-level requirements for the 244-AR Vault Interim Stabilization Project are to remove the pumpable liquids from the estimated $72,105 \mathrm{~L}$ (19,050 gal) of waste in the 244-AR Vault Facility and meet the other requirements of TPA Interim Milestones M-45-11 and M-45-11A. The criteria for the stabilization of the facility are listed in the TPA Change Control Form M-45-99-02 (see Figure 1-1). The six criteria for the stabilization of the facility are as follows:

1. The removal of pumpable liquids from 244-AR vault tanks

2. The removal of pumpable liquids from the vault itself and its associated sumps

3. Isolation of the $244-A R$ vault

4. Provisions for the removal of pumpable liquids which may accumulate in the future

5. Installation of intrusion prevention mechanisms as may be necessary

6. Establishment of periodic liquid-level monitoring systems for the detection of accumulating liquids prior to final closure. 


\section{RPP-5635 REV 0}

The TPA Interim Milestone M-45-11 A also requires that the "Interim stabilization activity endpoint criteria will be established on approval of the Interim Stabilization project plan. At minimum the plan shall establish criteria for, and schedule interim stabilization activities".

The technical strategy for the stabilization of the facility is described in Section 3.0, and the endpoint criteria are defined in Appendix A.

\subsection{OBJECTIVES AND MEASURES OF SUCCESS}

The primary objective of the 244-AR Interim Stabilization Project is to provide for planning and project completion to satisfy the requirements for closure of the milestones. The measures will be based on the timeliness and completeness of the planning and the desired end states of the project work. These measures will be used to verify that the 244-AR team has executed its mission effectively. Table 2-4 summarizes the measures of success for the 244-AR Vault Interim Stabilization Project planning effort. Measures for the success of this project are included in Appendix A.

\subsection{STABILIZATION OPTIONS AND EVALUATION}

A dedicated project team was assembled to evaluate the alternatives for removal of the pumpable liquids from the 244-AR vault. The requirements of the mission are defined in TPA Interim Milestone M-45-11A. Because the schedule for preparation of the facility for deactivation and the deactivation itself have not yet been defined, equipment that is used or installed for stabilization and removal of the liquids was not assumed to stay in place or be maintained pending deactivation. Options for the removal of the pumpable liquid were limited because of the limitations on access to the liquid. The options centered on the access path to the liquid and the motive force to be used to remove the liquid. The alternatives evaluated were narrowed to the following three:

1. Facility restart (i.e., reactivate crane, lift cover blocks, use jumper system/steam jet)

2. Alternative configuration (i.e., use existing facility configuration without lifting the cover blocks/steam jet or alternative pump)

3. Temporary system (i.e., installation of a new system not requiring the lifting of cover blocks or the restarting of the steam system.)

During evaluation of the alternatives, the alternative configuration was eliminated because of the size and configuration of the existing facility piping. Options 1 and 3 were considered to be technically feasible. Operations cost history for the upgrading of facility equipment and maintenance requirements for the equipment for an undetermined period while awaiting cleanout and deactivation supported the installation of a temporary system. It was also determined that option 3 more closely met the provisions of the mission requirements. The temporary system would be put in place to pump the existing liquids and then left in place to satisfy the requirements for potential future pumping of intrusions. 
Table 2-4. Measures of Success for 244-AR Vault Stabilization Planning.

\begin{tabular}{|c|c|c|}
\hline Performance Deliverable & Source & Measure of Success \\
\hline $\begin{array}{l}\text { Submit 244-AR Vault Stabilization } \\
\text { Project Plan to DOE by } 3-30-00 \text {. }\end{array}$ & PI ORP3.3.1 & $\begin{array}{l}\text { Submit the Project Plan to ORP by formal } \\
\text { letter by March } 30,2000 .\end{array}$ \\
\hline $\begin{array}{l}\text { Address the six items listed under TPA } \\
\text { Interim Milestone M-45-11A to } \\
\text { "stabilize" the } 244-A R \text { vault. }\end{array}$ & PI ORP3.3.1 & $\begin{array}{l}\text { Address the stabilization activities as } \\
\text { defined in the Performance Incentive. } \\
\text { 1. The removal of pumpable liquids } \\
\text { from 244-AR Vault tanks. } \\
\text { 2. The removal of pumpable liquids } \\
\text { from the vault itself and its associated } \\
\text { sumps. } \\
\text { 3. Isolation of the 244-AR Vault. } \\
\text { 4. Provisions for the removal of } \\
\text { pumpable liquids which may } \\
\text { accumulate in the future. } \\
\text { 5. Installation of intrusion prevention } \\
\text { mechanisms as may be necessary. } \\
\text { 6. Establishment of periodic liquid level } \\
\text { monitoring systems for the detection } \\
\text { of accumulating liquids prior to final } \\
\text { closure. }\end{array}$ \\
\hline $\begin{array}{l}\text { Describe the scope of work necessary to } \\
\text { stabilize the 244-AR vault. }\end{array}$ & PI ORP3.3.1 & $\begin{array}{l}\text { Include scope of work required. } \\
\text { (reference Project Plan Chapter 6) }\end{array}$ \\
\hline $\begin{array}{l}\text { Provide a cost estimate for performing } \\
\text { the work required to stabilize the } 244-A R \\
\text { vault. }\end{array}$ & PI ORP3.3.1 & $\begin{array}{l}\text { Include cost estimate for work required. } \\
\text { (reference Project Plan Chapter 6) }\end{array}$ \\
\hline $\begin{array}{l}\text { Provide schedule for completion of the } \\
\text { work to stabilize the } 244-A R \text { vault. }\end{array}$ & PI ORP3.3.1 & $\begin{array}{l}\text { Include a schedule for work required. } \\
\text { (reference Project Plan Chapter 6) }\end{array}$ \\
\hline $\begin{array}{l}\text { Closure of TPA Interim Milestone } \\
\text { M-45-11A. }\end{array}$ & TPA M-45-11A & $\begin{array}{l}\text { Contractor submittal of recommendation } \\
\text { to ORP for closure of the milestone based } \\
\text { on Project Plan submittal to DOE by } \\
\text { March } 30,2000 \text {, for submittal of approval } \\
\text { to Ecology by April } 30,2000 \text {. }\end{array}$ \\
\hline
\end{tabular}




\subsection{PATH FORWARD}

The selected path forward provides for interim stabilization of the 244-AR Vault Facility. This activity will accomplish the requirements of TPA Interim Milestone M-45-11 as explained below.

\subsubsection{Liquid Transfer}

The transfer of the pumpable liquids will be accomplished through the installation of a temporary pumping system that does not require the removal of the cover blocks, resetting of piping jumpers, or reactivation of the steam jets. Access to the liquids in the cell sumps and the process tanks will be through existing access holes in the cover blocks or by boring additional holes through the cover blocks. Access to the tank inventory will be gained by use of an existing opening (nozzle) in the top of the tanks or by cutting an additional hole in the tank for the insertion of a pump or suction leg. The actual transfers will be performed in two phases. The first phase will transfer the pumpable liquids internally, within the 244-AR vault, to consolidate the existing liquids from the vault tanks and sumps into a single tank. Tanks 001 AR and 002AR are candidates for this consolidation because of their capacity. The second phase would transfer the liquid from the consolidation tank within the 244-AR vault to the DST system in the 200 East Area, by way of the 241-AR-151 diversion box.

\subsubsection{Isolation and Intrusion Prevention}

The 244-AR Vault Facility will be isolated from process lines such as water and steam to prevent the reintroduction of liquids to the facility. Waste transfer lines that connect the 244-AR Vault Facility to B Plant, diversion boxes, or other DST facilities will also be isolated to prevent the reintroduction of waste to the facility. The primary method of isolation is to provide a mechanical block in these lines either at the supply end of the line segment connecting to the vault or within the 244-AR vault itself. Lines that connect the 244-AR vault with other structures internal to the 244-AR Vault Facility will require only confirmation that the isolation is upstream from the facility. An alternative method of isolation for seepage into buried vaults or buried encasements may be an evaluation to verify that precipitation/snowmelt does not penetrate to the depth of the structure.

Intrusion paths for precipitation and snowmelt that have been confirmed as a source of liquids in the past will also be mechanically blocked. Typical blocking mechanisms used in the past include grouting the drains that connect to the vault, foaming over the vaults and pits containing drains routed to the vault, and repairing the roofs that allow leakage access to the drains connected to the vault. 


\section{RPP-5635 REV 0}

\subsubsection{Facility Monitoring}

Liquid-level monitoring equipment will be installed or current equipment left in place in each of the sumps to detect any future accumulation of liquid. These instruments will be maintained, and read periodically.

\subsubsection{Capability to Pump}

The pumping system used to transfer the pumpable liquid from the 244-AR vault will be left in place to assist in the removal of any liquids that may accumulate after the isolation of the 244-AR vault. Services using a temporary or portable source such as a water truck, portable air compressor, power generator, or portable ventilation system during the pumping will not be required to remain in place in anticipation of a future intrusion but will maintain the pathway for future connection. 
RPP-5635 REV 0

This page intentionally left blank. 


\subsection{TECHNICAL STRATEGY}

\subsection{TECHNICAL OBJECTIVE}

The primary technical objective of the 244-AR Vault Interim Stabilization Project is to stabilize the vault by removing the remaining pumpable liquid from the 244-AR vault tanks and sumps. Liquids are known to be present in all four of the process tanks and in one of the three sumps. It is also planned to verify that the failed-equipment storage tubes do not contain any pumpable liquid. In parallel to the effort to remove the liquids, two additional tasks will be performed.

- The facility will be isolated from process liquid and waste transfer lines to prevent any future introduction of liquids into the vault.

- The known paths of liquid intrusions such as precipitation/snowmelt or condensate drainage will be blocked to prevent future introduction to the 244-AR vault. Monitoring capability will be left in place in the sumps to detect any future intrusions of liquid. The pumping and transfer system will be left in place to the extent possible to allow for future liquid removal should such intrusions occur.

\subsubsection{Liquid Removal}

The pumpable liquid in the vault (see Figure 2-1) will be removed in accordance with the criteria and deliverables defined in Appendix A. This objective includes the design, fabrication, testing and installation of a transfer system that will permit pumping the liquid to a receiving DST. This system must be reusable after minor maintenance, both preventive and corrective, have been performed and temporary services have been reconnected.

\subsubsection{Isolation}

The piping now connected to the 244-AR vault will be mechanically blocked to prevent the reintroduction of liquids to the vault. Process lines as well as waste transfer lines will be blocked in accordance with the criteria and deliverables in Appendix A.

\subsubsection{Intrusive Prevention}

The known paths for the intrusion of precipitation/snowmelt will be blocked to prevent future intrusions to the 244-AR vault. These paths include designed paths such as facility drains as well as suspected paths from roof leaks and vault cover leaks. This work will be performed to the criteria and deliverables defined in Appendix A. To support this effort a camera will be inserted into each of the failed equipment storage tubes to verify that there is no pumpable liquid present. An inventory will be made at that time of any hardware being stored in the tubes. 


\section{RPP-5635 REV 0}

\subsection{TECHNICAL APPROACH}

The technical approach to stabilizing the 244-AR vault requires equipment and activities in five main areas:

- Designing and installing a system that will consolidate the pumpable liquid from three tanks and sump 3 into one tank and subsequently transferring the combined waste to a designated DST

- Isolating waste transfer and process lines

- Preventing intrusions

- Monitoring tanks and sumps

- Establishing provisions for future pumping.

\subsubsection{Waste Consolidation and Transfer System}

The system for consolidating and transferring waste will require installing equipment and implementing a supporting AB. The NS\&L strategy to support installation and operation of this system is discussed in Section 4.2.

The waste consolidation and transfer system comprises a number of components and subassemblies. Major components, subassemblies, and support systems include the following:

- Consolidation manifold

- Drop legs

- Transfer line

- Sampling system

- Instrumentation and control

- Ventilation

- Chemical adjustment.

A diagram of the consolidation and transfer system is shown in Figure 3-1.

3.2.1.1 Consolidation Manifold. This subassembly is a common header connecting the drop legs, flush water, and the transfer route to the vault boundary and transfer line. The manifold consists of a single-wall pipe with in-line couplings to facilitate handling and entry into the 244-AR vault, and solenoid- or motor-operated valves at each of the drop legs. Through pump operation and valve configuration, waste can be consolidated from sump to tank and tank to tank. Once the consolidation activity or final transfer has been completed, the lines and pumps must be flushed. To facilitate this activity, a quick-disconnect coupling will be provided on the manifold, with routing via a flexible hose and a vault wall penetration, to permit connection to a water truck, and/or a compressed air system to flush and purge the manifold. The manifold will include connections that can be used to install transfer-pump assemblies into sumps 1 and 2 and the failed equipment storage tubes if necessary. These areas do not contain liquid, but will be made accessible to meet the requirements of Section 3.2.5. 


\section{RPP-5635 REV 0}

Figure 3-1. 244-AR Vault: Temporary Transfer System Diagram.

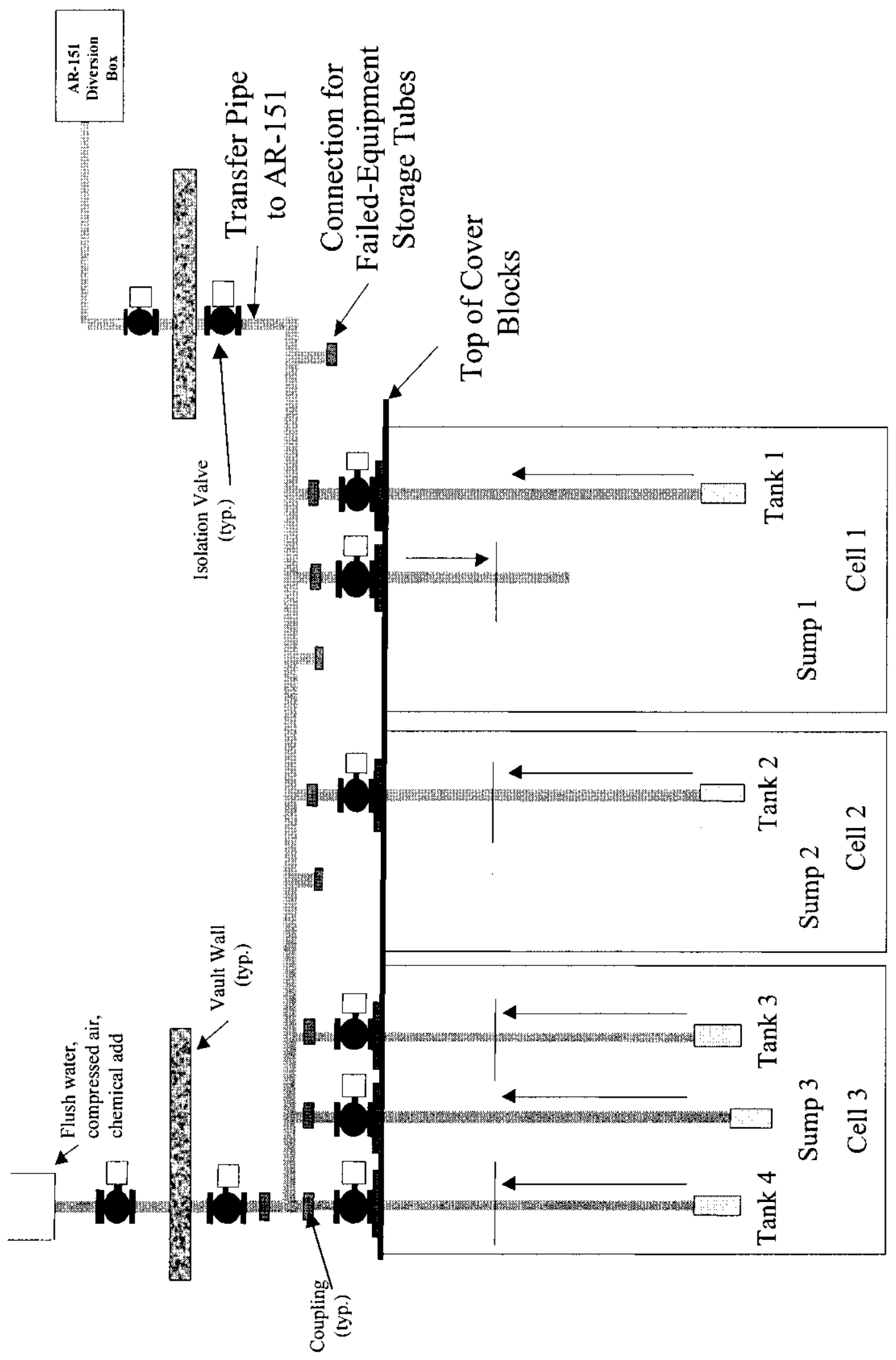


3.2.1.2 Drop Legs. Two types of drop legs, pump (out) and return (in), are being used. All of the drop legs will connect to the manifold with a quick-disconnect coupling and an isolation valve above the cover blocks.

The pump legs connect to the manifold quick-disconnect couplings and extend through the isolation valve, which is located above the cover blocks, and connect to a submersible pump by means of chemical-resistant hose or pipe that is lowered into the tank or sump. The pump legs will be inserted into the sumps and tanks through existing access ports or holes that are core drilled through the cover blocks and, if required, through the top of each tank.

The return leg connects to the manifold quick-disconnect coupling and extends through the isolation valve, which is located above the cover blocks, into the consolidation tank by means of chemical-resistant hose or pipe. The return leg will also incorporate a flow meter (for flow indication only). The return leg will be placed in Tanks 001AR or 002AR because of their capacity. The primary purpose of this leg is to provide an inflow path to consolidate tank and sump waste. Its secondary purpose is to provide a circulation path if the consolidation tank contents require circulation before sampling or after chemical adjustment. Design and location of the return leg into the tank will include the mixing capability considerations.

For drop leg installation, a core-drilling machine and a high-pressure water jet cutter will be used.

- Core-drilling machine - A core-drilling machine will be used to drill additional access holes. Seven holes, estimated at $0.152 \mathrm{~m}(6 \mathrm{in}$.) to $0.203 \mathrm{~m}$ (8 in.) in diameter, will be added through the cover blocks above the tanks and sumps. Three holes, one in each of the failed equipment storage tube cover blocks, estimated at $0.102 \mathrm{~m} \mathrm{(4} \mathrm{in.)} \mathrm{in} \mathrm{diameter}$ will be drilled for inspection of the tubes. Three holes (estimated at $0.152 \mathrm{~m}$ [6 in.] in diameter) through the north canyon wall will be added to facilitate the transfer line, instrumentation and controls, and utilities. A diagram of the existing penetrations in the cover blocks and conceptual location of required core bores is shown in Figure 3-2.

- High-pressure water jet cutter - This machine uses high-pressure water $(\sim 206.84 \mathrm{Mpa}$ [30,000 psi]), gravity-fed garnet abrasive, and a manually controlled directional cutting nozzle to cut strategically located holes into the tops of the tanks to facilitate drop leg insertion. This process has been widely used by industry and previously used at Hanford to slot-cut the saltwell screen inside Tank 241-A-101.

Submersible pumps will be used to consolidate the liquid waste and transfer the consolidated liquid waste to a DST. The consolidation pumps may be submersibles that can be cascaded, if necessary, to ensure that the required pumping head is achieved. Final pump selection, during the design phase, will consider pump availability, core bore requirements and tank top hole size requirements. The pump used to transfer liquids from the 244-AR vault is a larger-diameter submersible pump that is used to pump directly either to a DST or to a cover-block-mounted booster pump that then is used to transfer the consolidated waste to the receiving DST. 
Figure 3-2. 244-AR Waste Removal Concept Cell Access/Core Drill Locations.
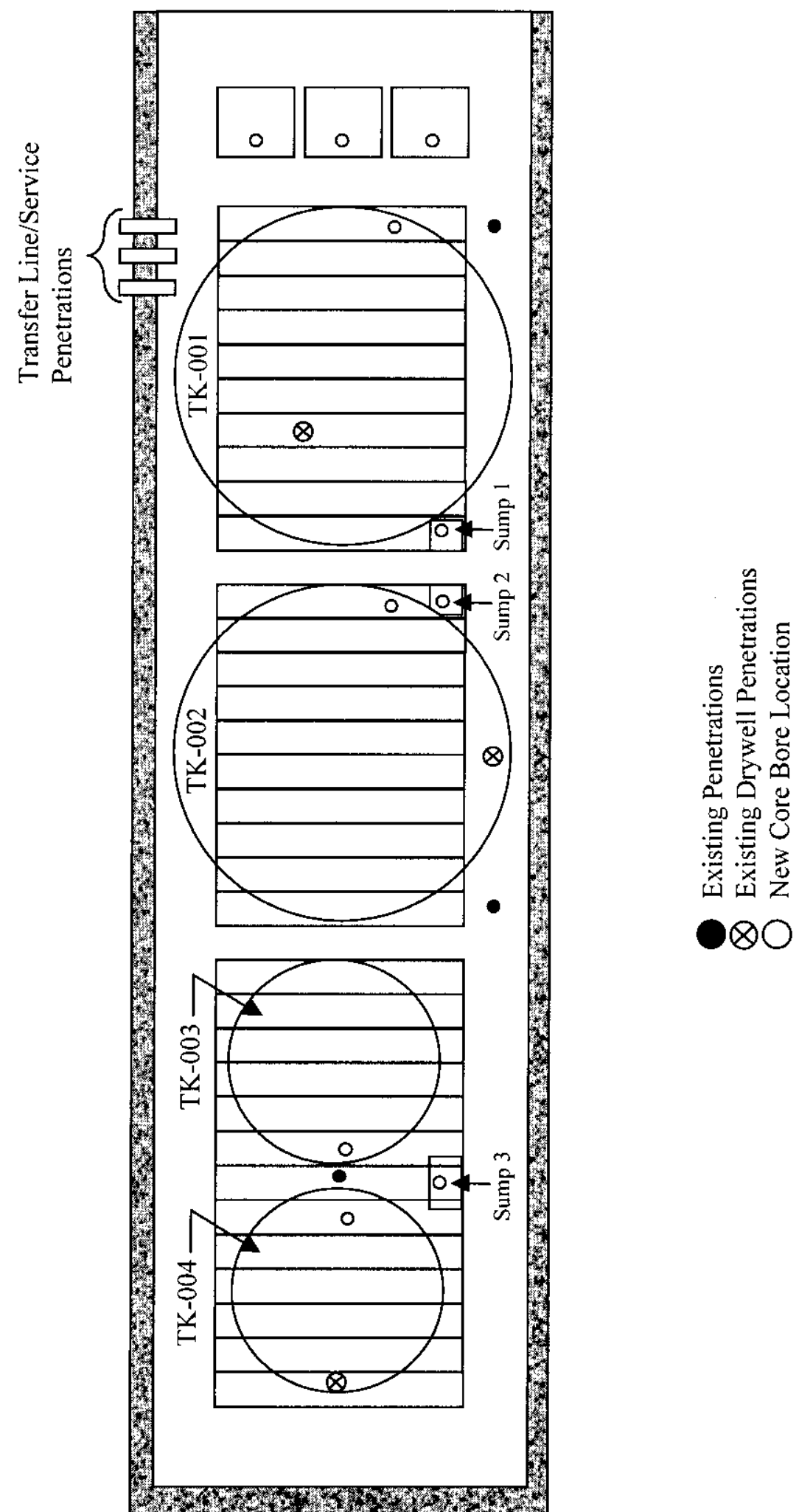
3.2.1.3 Transfer-Line Assembly. This subassembly connects the pump in the consolidation tank and the manifold to the wall nozzle in the 241-AR-151 diversion box. The canyon portion of the assembly consists of a single-wall pipe, booster pump (if required) solenoid- or motor-operated valves, pressure indicator, and flow totalizer. The portion of the transfer line located outside of the canyon consists of a double-encased pipe, encasement leak detection, and solenoid- or motor-operated isolation valve. This portion exits the north canyon wall and is routed below grade to a spare nozzle on the south side of the 241-AR-151 diversion box.

3.2.1.4 Sampling System. This subassembly is used to sample the contents of the consolidation tank during circulation. It is connected by means of valves and tubing to the pump-out line and circulation line. This system will provide the capability to discharge into a sampling bottle or pot that can be sent to a lab for analysis.

3.2.1.5 Instrumentation and Control System. The instrumentation and control system allows for remote operation of the transfer pumps and valves and monitoring of the transfer process. The control panel for the instrumentation and control system will be located outside the canyon. The operator/control system interface is anticipated to be a control panel similar in design to that used at the 204-AR Waste Unloading Facility. It contains the controls used to operate the transfer pumps and valves. The control system will use manual switches with lighted valve-position indicators.

The instrumentation system will use both new and existing systems or components. The new components consist of transfer-line pressure indicators, a transfer-line flow totalizer, a consolidation-line flow meter, and encasement leak detection. The existing tank and sump level indicators and the tank-dome-space pressure indicators will continue to be used. System alarms will be limited to encasement leak detection. Manual pump shutdown will occur on actuation of the alarms.

3.2.1.6 Ventilation. Two ventilation systems, vessel vent and canyon vent, will be installed at the facility.

- Vessel vent - This unit will ventilate the tanks during canyon work and transfers. This exhaust path will use a portable exhauster currently available in Tank Farm Operations. It will connect to the vessel vent duct located on the north side of the 244-AR vault.

- Canyon vent - The canyon vent system is sized to maintain a slightly negative pressure in the canyon during normal operations (all doors closed with no forced supply air). It will be connected to one of the "dog houses" that is part of the old ventilation system. This exhaust path will require the procurement of a portable exhauster because of the flow rate requirements of the canyon facility.

3.2.1.7 Chemical Adjustment. Following the consolidation of the waste, the results of the initial $\mathrm{pH}$ test will be used to determine what chemical adjustment is required (primarily $\mathrm{NaOH}$ and $\mathrm{NaNO}_{2}$ ) for transfer to a DST. The chemicals will be pumped from a chemical truck into the consolidation tank through the new line and manifold. The tank contents then may be circulated in the consolidation tank by means of the transfer system if additional mixing is required to ensure that the chemicals remain in solution. 
An alternative route for the addition of chemicals to the tanks if required, is the existing chemical addition line that is located outside the vault (adjacent to the service building entrance). The chemicals could be pumped to the existing manifold inside the control room from which they then could be routed to each tank as required. On completion of the waste transfer, this line will be capped but remain available to support the milestone requirement for future pumping capability.

3.2.1.8 Utilities. The utilities required for 244-AR vault stabilization include the electrical power (required to operate the pumps, valves, and instrumentation), compressed air, flush water, chemical addition, and dilution water. Power to operate the pumps will be obtained from existing motor control centers that supply power to the canyon or from an auxiliary generator. The flush water and chemical adjustment solution will be supplied from water and chemical trucks. Compressed air (primarily to blow down the transfer line after the transfer) will be obtained either from the facility air compressor or from a portable compressor. The air system will share the flush water connections external to the $244-A R$ vault.

3.2.1.9 Mock-up Testing. Three mock-up configurations are anticipated for developing, refining, and testing of the concepts to be used to support pump installation:

- Developing the techniques to be used to core bore through the $1.5 \mathrm{~m}(5-\mathrm{ft})$ thick cover blocks and the $0.61 \mathrm{~m}(2-\mathrm{ft})$ thick cover blocks on the failed equipment storage tubes.

- Developing the configuration for and methods of using the high-pressure water jet cutter to cut a hole in the top of each of the process tanks.

- Developing the technique for inserting the pumps through the cover block penetrations and the hole in the tank top to position the pump for operation. This setup also would be used to verify the pumping capability of the selected pumps.

Additional mock-up activities may be identified during the preliminary design phase of the project.

\subsubsection{Waste Transfer and Process Line Isolation}

One of the requirements of TPA Interim Milestone M-45-11 is to isolate the 244-AR vault. Isolation of the vault will require addressing waste transfer lines and process lines. Figure 3-3 shows the general waste transfer and process line layout and the locations where isolation could be achieved.

3.2.2.1 Waste Transfer Lines. There are two types of transfer lines used at the 244-AR Vault Facility. One type is used to make transfers between facility tanks and sumps; the other is used to transfer waste to or from outside facilities such as SSTs, DSTs, PUREX, or B Plant. Many of these routes go through diversion boxes. Because the sump-to-tank and tank-to-tank transfer lines are within the scope of the facility boundary, they do not have a source of liquid, and isolation is not required. All external waste transfer lines penetrate the 244-AR vault on the north wall of the cells and connect either to a diversion box or to B Plant. 


\section{RPP-5635 REV 0}

Figure 3-3. Waste Transfer and Process Line Isolation Points.

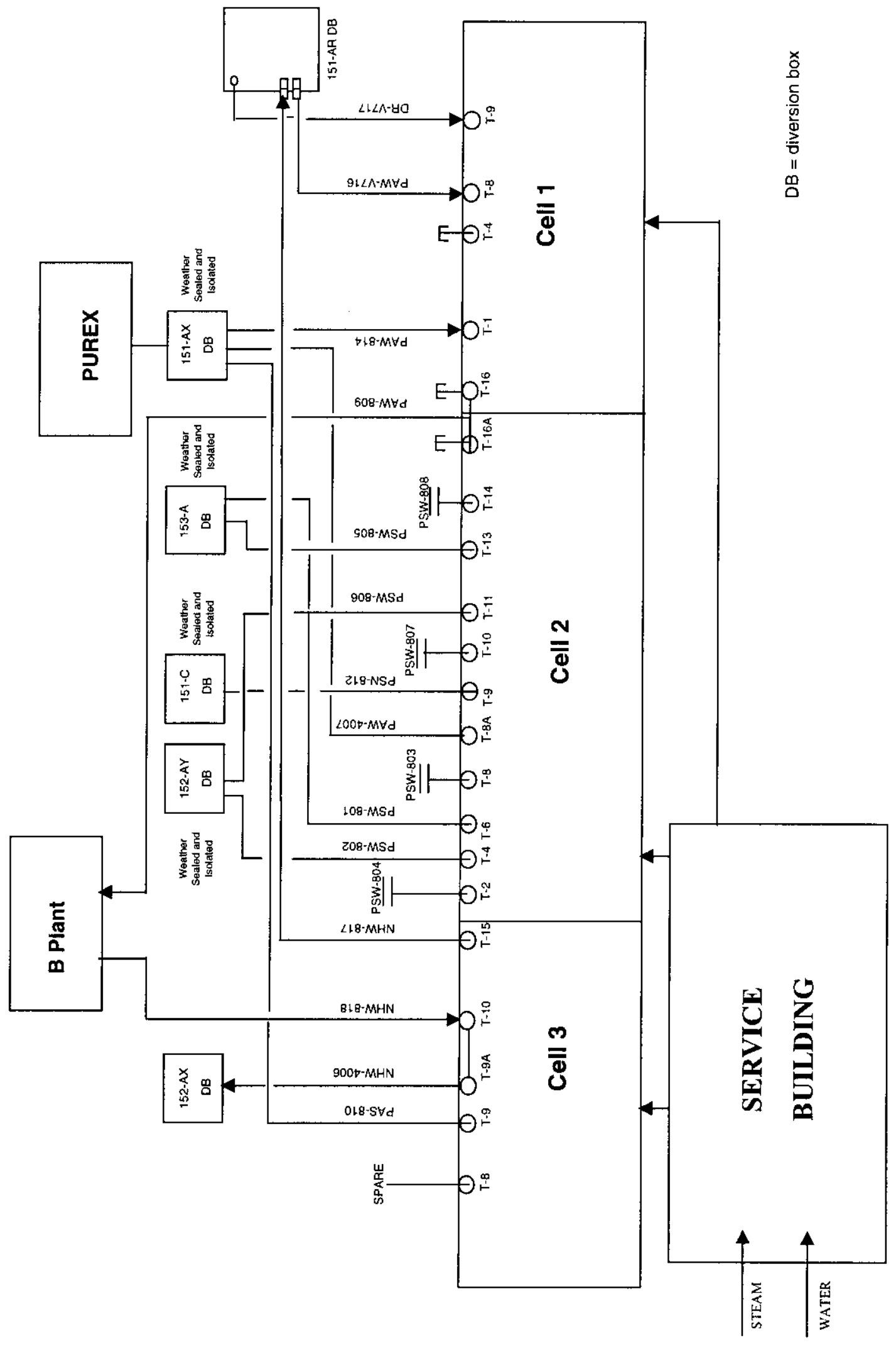


This activity will ensure that the transfer lines are isolated at the north wall nozzle, inside 244$\mathrm{AR}$, or at the other end of the line segment, within a diversion box, or B Plant. This activity will not require that transfer lines be blocked at both ends.

3.2.2.2 Process Lines. Process lines are lines that supply various services to the 244-AR Vault Facility and typically enter from the south side of the vault. For this activity, the lines to be isolated are limited to the following:

- Water lines - All water to the facility has been isolated as a result of two water line ruptures that occurred in January 1997. This activity is limited to ensuring that the line isolation is located and documented.

- Steam lines - Steam to the facility was provided by a steam line that passes through PUREX. This line is reported as being isolated. This activity may also pull and blank the steam isolation valve in 244-AR ensuring that the steam line isolation is located and documented.

\subsubsection{Intrusion Prevention}

TPA Interim Milestone M-45-11 includes a requirement to prevent further intrusion of liquids into the 244-AR vault. A diagram of the intrusion boundary is shown in Figure 3-4. A number of paths, including the following, are available:

- Service Building roof/floor drains

- Canyon roof

- Canyon vent inlet duct

- Filter Building drain lines

- Stack drain lines

- Canyon entrance rain gutter discharge

- Seal pot overflow.

This activity will identify all known intrusion paths and implement various preventive measures to mitigate the possibility of future liquid intrusions. Some methods of isolation include, but are not limited to, the following:

- Grouting/plugging floor drains

- Sealing roofs

- Sealing filter buildings

- Cutting and capping drain lines where possible

- Grouting collection tanks

- Installing semi-permanent pipe plugs

- Sealing vault/box covers

- Evaluation of buried structures. 


\section{RPP-5635 REV 0}

Figure 3-4. 244-AR Vault Intrusion Boundary.

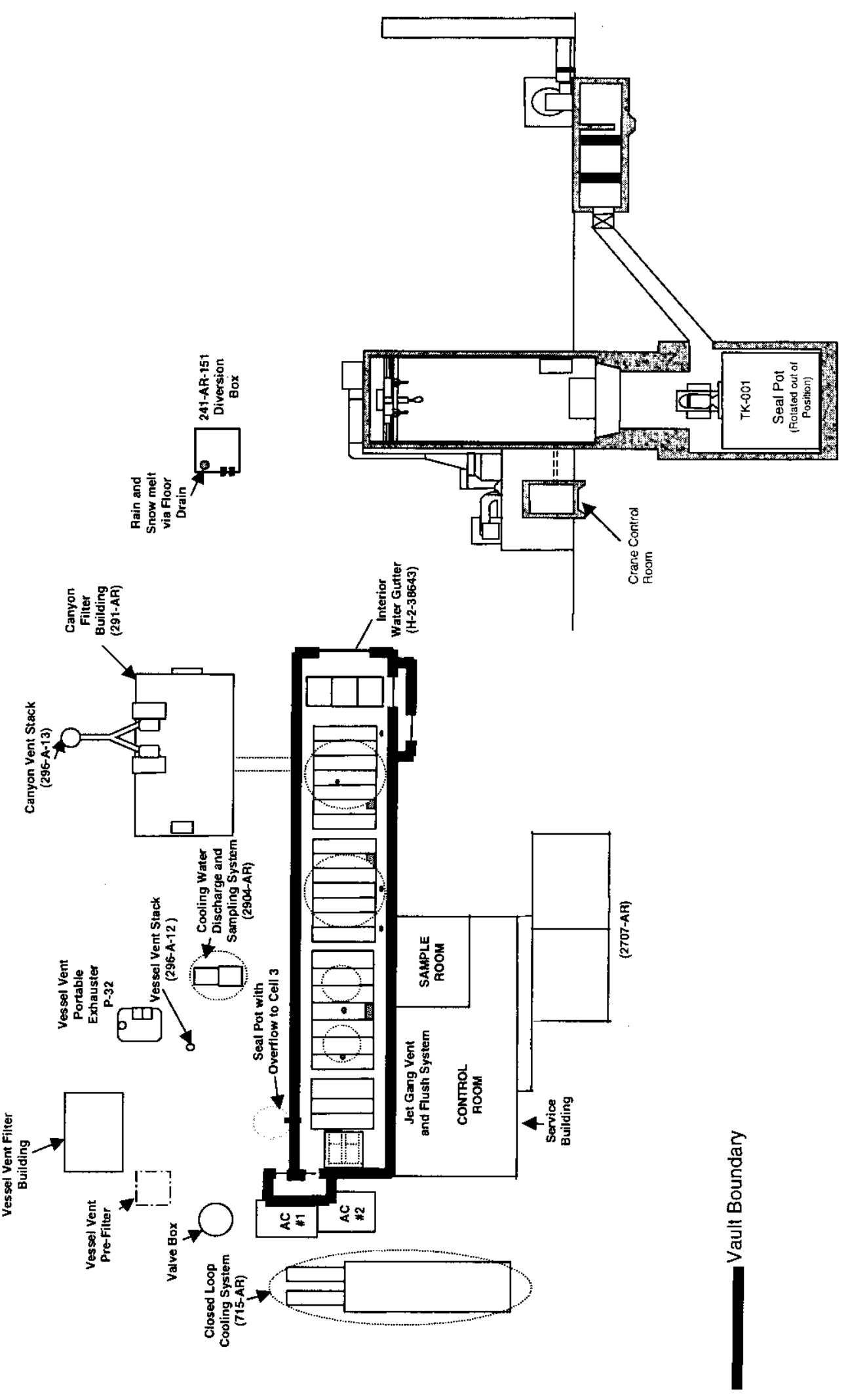




\subsubsection{Monitoring}

Plans are to use the existing facility monitoring system, consisting of weight-factor transmitters, strip chart recorders, and level alarms, to monitor the condition of the facility. This system is being used to satisfy the WAC 173-303 requirement for daily monitoring and will be used during the 244-AR Vault Facility stabilization work. Upgrades of the system by Tank Farm Operations are planned for completion in FY-00. Following stabilization of the 244-AR vault, monitoring will be limited to the sumps only, and the frequency of the readings will be reduced to quarterly. This system is not now, nor planned to be, connected to the Tank Monitor and Control System (TMACS).

\subsubsection{Provisions for Future Pumping}

To satisfy the TPA Interim Milestone M-45-11, a transfer system must be available to remove any liquid that may intrude into the vault once the initial pumpable quantity of liquid has been removed. The transfer system used to remove the initial pumpable liquid will be laid up in the facility and be available to provide future pumping capability to each of the tanks and to sump 3 . The manifold will include connections for pump leg assemblies into sump 1, sump 2, or any of the failed-equipment storage tubes if necessary in the future. Temporary services will require re-connection if future pumping is required.

\subsubsection{Use of Existing Technology.}

The transfer system and monitoring system will use off-the-shelf commercial components. New technology is not expected to be required.

\subsubsection{Staffing}

Current Tank Farm Operations staff will perform the project work. Task-specific training will be provided as required. 


\section{RPP-5635 REV 0}

This page intentionally left blank. 
RPP-5635 REV 0

\subsection{PROJECT STRATEGY}

\subsection{OPERATIONS AND MAINTENANCE}

Equipment installation, operations, and maintenance activities are key to the success of the 244-AR Vault Interim Stabilization Project. Sections 4.1.1 and 4.1.2 address project strategy as it relates to operations and maintenance personnel.

\subsubsection{Operations Strategy}

The operations strategy for the 244-AR Vault Interim Stabilization Project is based on the applicable requirements established in DOE Order 5480.19, Conduct of Operations Requirements for DOE Facilities. The applicability matrix for DOE Order 5480.19 is defined in HNF-IP-0842, Volume 2, Section 4.1.1 (LMHC 1999)

The operations strategy must support two separate activities: equipment installation and waste transfer operations. To support the installation and testing of project equipment while maintaining adequate support for other Tank Waste Operations (TWO) projects, a team of personnel will be selected from several TWO organizations. This team will be matrixed to the 244-AR Project manager and will be assigned for the duration of the installation activities. Generally, this team will support operations on day shift only, but may be assigned to shift work if required for installation or testing activities.

The operations approach to support the actual transfer is patterned after the Interim Stabilization organization pumping team. Because transfer activities are of a relatively short duration, only a dedicated group of personnel will receive the training required to perform the transfers. This group will be assigned to staff the transfer operation as needed to avoid unnecessary shutdowns.

\subsubsection{Maintenance Strategy}

The maintenance strategy for the 244-AR Vault Interim Stabilization Project is based on the requirements established in DOE Order 4330.4B, Maintenance Management Program, Chapter 2, "Maintenance Optimization for Essential Equipment Reliability"; INPO 85-032, Preventive Maintenance, Good Practice MA-307; and INPO-89-009, Plant Predictive Maintenance, Good Practice MA-316.

The strategy consists of a preventive and predictive maintenance program that includes the proper skill mix of crafts to install and remove equipment and to provide preventive, predictive, and corrective maintenance. Resources will be assigned from the RPP Maintenance Organization (East Area Maintenance). Because the actual operating schedule is of very short duration, calibration and preventive maintenance will be performed one time before startup and then on an as-needed basis over the term of the actual transfer. The strategy is designed to balance early detection of conditions with actions that will ensure reliability and as-low-as- 
reasonably-achievable (ALARA) consideration of maintenance personnel. If necessary, shift support and/or weekend overtime will be used during transfer activities to meet the schedule.

Maintenance of 244-AR vault level monitoring instrumentation is funded and maintained by Tank Farm Operations; post-stabilization funding and maintenance of this equipment will continue to be handled in the same manner and is excluded from this project maintenance strategy.

\subsection{NUCLEAR SAFETY AND LICENSING}

The NS\&L strategy for this project is to provide needed amendments for pumping liquids from the vault and to obtain DOE approval as required. Depending on the final details of the design, such amendments may include a hazard evaluation, accident analysis, controls, and DOE approval before work begins. Alternatively it may require only an update of the FSAR once the work is finished. As a result of the work, analysis, and licensing tasks, it is likely that this facility (Tank 002AR of 244-AR) will be able to be removed from the flammable gas USQ list.

\subsubsection{Nuclear Safety Analysis Process}

The nuclear safety analysis process starts with a comparison of the existing $\mathrm{AB}$ (the amended FSAR) to the planned activities (collecting pumpable liquids in one tank and then pumping the liquid to a DST). A USQ screen will be performed on the planned activities. If there is no USQ, the project can proceed with facility changes and execution of the plan. If there is a USQ, then an amendment will have to be drafted and submitted to DOE for approval through a safety evaluation report (SER).

If the transfer of the waste results in a USQ, the existing analysis in the FSAR will be used, e.g., surface leak resulting in a pool, leakage from underground pipe resulting in a pool.

The anticipated as-left status of the vault and its contents will be compared to the existing description in the FSAR. Regardless of whether an approved amendment is needed before the work because of a USQ, the FSAR will have to be changed to reflect both the changes in waste contained in the vault and other changes that result from the work. This type of change does not require DOE approval.

\subsubsection{Authorization-Basis Documentation and Licensing Actions}

In addition to the flammable gas USQ issue, a 244-AR vault-specific concern was raised when liquid was observed in cell 3. A hazards evaluation was done (HNF-4453, Hazard Evaluation for 244-AR Vault, Bloom, J. W., 1999, Lockheed Martin Hanford Corporation). It was followed by an accident analysis (RPP-4779, Analysis of Postulated Flooding Accident in the 244-AR Vault, Himes, D. A., 1999, Lockheed Martin Hanford Corporation). This latter analysis was done to verify that the results of a specific threat at 244-AR (a floating tank) are bounded by an 
existing accident analysis, surface leak resulting in pool. Because of this issue, an amendment to the FSAR was submitted in September 1999. DOE approved the amendment on December 16, 1999.

As a result of the interim stabilization work, the quantity of material at risk in the 244-AR vault will be reduced and better characterized than it is now. The result will be a more accurate hazard evaluation/accident analysis, if required for future lay-up controls, than those based on assumptions about waste composition. The thoroughness of the removal of the liquid and other waste will determine how the facility is classified.

\subsection{PERMITTING}

The environmental permitting strategy addresses the permits or other environmental documents required to initiate the proposal of pumping 244-AR liquid via a temporary transfer system to the DST System.

\subsubsection{Assumptions}

Assessment of the environmental permitting requirements was based on the following assumptions:

- The 244-AR Project will conduct intrusive activities, exhauster activities, and pumping activities that may emit radioactive or toxic constituents to the air and therefore require approved radiological and non-radiological notices of construction.

- The proposed response does not involve the use or introduction of chemicals significantly different from existing tank inventories or different from typical transfer procedures.

\subsubsection{National Environmental Policy Act}

The National Environmental Policy Act (NEPA) requires Federal agencies to analyze potential environmental effects of proposed actions during the decision making process. A similar Washington state law, the State Environmental Policy Act (SEPA) requires state agencies such as the Washington State Department of Ecology (Ecology) to analyze environmental effects before making decisions. Because NEPA and SEPA requirements are similar, the DOE and Ecology co-prepared DOE/EIS-0189 Final Environmental Impact Statement for the Tank Waste Remediation System. All of the River Protection Project EIS alternatives analyzed include on-going activities to manage the tank waste safely, e.g., transferring waste between the tanks; operating waste transfer pumps; waste characterization; maintaining tank safety activities; and other associated monitoring, maintenance, security, and regulatory compliance activities. No additional NEPA or SEPA documentation is required before activities at the 244-AR Vault Facility begin. 


\subsubsection{Resource Conservation and Recovery Act (RCRA)}

Ecology has been delegated authority by the EPA to administer the base RCRA program in place of the federal program. Ecology RCRA requirements are found in the Dangerous Waste Regulations, Chapter 173-303 of the Washington Administrative Code (WAC). The RPP is operating under "Interim Status" standards located in WAC 173-303-400 and also operates within a RCRA Part A permit per WAC 173-303-800. Plans for the transfer of pumpable liquids from the 244-AR vault require that a modification to the Part A Permit be made to add the applicable waste code.

\subsubsection{Clean Air Act (CAA)}

The primary federal and state regulations containing air permitting requirements applicable to the 244-AR Project are contained in 40 CFR 61, National Emission Standards for Hazardous Air Pollutants (NESHAPS); WAC 173-400, General Regulations for Air Pollution Sources; WAC 173-460, Controls for New Sources of Toxic Air Pollutants; and WAC 246-247, Radiation Protection-Air Emissions. Ecology is the lead Washington state agency enforcing pollution regulations, while the Washington State Department of Health (WDOH) is designated as the state radiation control agency per the Revised Code of Washington (RCW) 70.98. The EPA has partially delegated NESHAPS authority and enforcement responsibilities to WDOH. For the purposes of triggering air permitting requirements, any modifications and means of emitting toxic air pollutants or criteria pollutants must be examined and permitted by Ecology. Any means of emitting radioactive particulate to the air via the processes necessary to establish the transfer line and pump the liquids must be permitted by WDOH and EPA. Thus, both a radiological and non-radiological notice of construction (NOC) must be submitted and approved before work begins at $244-\mathrm{AR}$.

\subsection{READINESS ASSESSMENT}

The DOE Order 425.1A, "Startup And Restart Of Nuclear Facilities," establishes the requirements for startup of new nuclear facilities and for the restart of existing nuclear facilities that have been shut down. HNF-IP-0842, Volume I, Section 1.2, "Readiness Review Process," implements DOE O 425.1A for CHG. CHG performed a preliminary startup review determination for 244-AR Vault Interim Stabilization activities. The startup review determination uses a graded approach to examine the scope of the proposed activity and document the thought processes and logic used in determining the required depth of review. As a result of the preliminary determination, $\mathrm{CHG}$ intends to perform a readiness assessment for 244-AR Vault Interim Stabilization activities. This determination assumes that the stabilization will be a short-duration, one-time activity to prevent weather-related water intrusion and to clean out systems or components incidental to decontamination and deactivation activities. Also taken into account was the stabilization plan, present design, operations, and $\mathrm{AB}$. The stabilization equipment design, installation, and operation are essentially the same as found throughout the tank farms. A USQ screen will be performed on the planned activities. If no USQ arises, the project can proceed with facility changes and execution of the plan. If a USQ should arise, then an amendment needs to be drafted and submitted to DOE for approval through an SER. 


\section{RPP-5635 REV 0}

Technical Operations and Engineering, Production Control, Maintenance, Radiological Control, and Operations personnel have been trained in the controls and activities required to support this shutdown facility. While the unique aspects of 244-AR stabilization are appreciated, the stabilization activities essentially are tasks that are performed daily throughout the tank farms.

This strategy provides guidance to line management and plant personnel for completing startup preparations in accordance with RLID 425.1A, Attachment 8.1, "Startup/Restart Requirement Summary"; and HNF-IP-0842, Volume I, Section 1.2. The HNF-IP-0842 procedure will be used to format the documents used in the readiness process. 
RPP-5635 REV 0

This page intentionally left blank. 


\subsection{ASSUMPTIONS AND RISK}

The assumptions below apply to the operations, technology and equipment, and the permitting of the 244-AR Vault Interim Stabilization Project. The assumptions were developed on the basis of the relative level of risk. If the assumptions are not valid, schedule and cost are likely to change and the project plan will need to be reevaluated. The schedule incorporates these assumptions into the planning basis.

\subsection{KEY ASSUMPTIONS}

Key assumptions are those that define the bounds of the project scope. If any of the key assumptions prove to be invalid, reevaluation of the overall effects on the program would be necessary. Following are the detailed key assumptions.

\subsubsection{Project Assumptions}

5.1.1.1 DOE Orders. The DOE-ORP will continue to manage the Hanford Site and the 244-AR Vault Facility until the project has been completed and the facility is compliant. DOE Orders are assumed to remain as they are, with no critical changes affecting the project.

5.1.1.2 Safety/Environmental Issues. It is assumed that no new safety or environmental reviews or requirements will be imposed that will affect the 244-AR Vault Interim Stabilization Project.

5.1.1.3 Funding Levels. Funding to meet the proposed baseline will be available to support project ramp-up and sustained operations. Funding shall be authorized sufficiently in advance to anticipate and prevent impacts to the schedule.

5.1.1.4 Support Systems. It is assumed that the analytical services facilities and the DST Farm support infrastructures will be maintained and scheduled to support this plan.

5.1.1.5 Post Stabilization Pumping. Monitoring and pumping of accumulated liquids after the facility is stabilized are not covered in the Project Plan and are outside the scope of the project.

5.1.1.6 Post Stabilization Ventilation. No tank or building ventilation will be required following stabilization.

5.1.1.7 B Plant Interface. Direct transfer lines from the 244-AR vault to B Plant (818/8653 and $809 / 8618$ ) are isolated within the B Plant facility.

\subsubsection{Operating Assumptions}

5.1.2.1 DST Space Availability. It is assumed that adequate space is available in the DST system for the transfer of waste from the 244-AR Facility. 
5.1.2.2 Training. Existing trained staff, including crafts, health physics technicians (HPT), Industrial Hygiene and chemical operators, will perform this work.

5.1.2.3 Flammable Gas. The presence of flammable gas (hydrogen) in Tank 002AR will not eliminate work on or in the tank.

5.1.2.4 Use of Existing Electrical Equipment. Routine minor maintenance will bring required existing equipment up to functional status.

5.1.2.5 Cover Blocks. The crane will not be operational and no cover blocks will be lifted to facilitate the removal of the pumpable liquids or isolation of the process and waste transfer lines.

5.1.2.6 Diversion Box AR-151. Diversion box AR-151 will be treated as part of the facility, as there are no plans for its future use other than 244-AR. The diversion box will be isolated and out of service at the completion of the project.

\subsection{ENABLING ASSUMPTIONS}

Enabling assumptions are those assumptions made because a decision is pending. The enabling assumptions allow development of cost and scheduling information; however, each enabling assumption carries with it the risk that the assumption is incorrect. The list of these operating enabling assumptions follows.

\subsubsection{Operating Enabling Assumptions}

5.2.1.1 Permitting for 244-AR Entry. No additional permits or NOCs will be required to enter the 244-AR canyon for the purpose of gathering data. Data gathering tasks include video below the cover blocks, taking dose readings in the dry wells, and gathering radiological data.

5.2.1.2 Operational Readiness. A readiness assessment with independent contractor review will be required.

5.2.1.3 Authorization Basis. It will be necessary to revise the current "inactive" facility status and allow the material to be transferred. Adjustments to the text of the $\mathrm{AB}$ will be required with use of existing controls.

5.2.1.4 Sampling Analysis. Consolidation of the cell/sump/tank waste within the facility will not require a sampling/compatibility assessment. Sampling/chemical adjustment of waste is required only before it leaves the facility.

5.2.1.5 DST Compatibility. With adjustments, waste is compatible for transfer to DSTs.

5.2.1.6 Facility Conditions. The structural integrity of the cover blocks for lifting will be maintained.

5.2.1.7 Labor Forces. Plant Forces Work Review will result in plant forces performing the work. 


\subsubsection{Equipment Enabling Assumptions}

5.2.2.1 Portable Exhausters. Exhauster capacity and contamination controls will allow work inside the canyon above the cover blocks to be performed without respirator protection.

\section{$5.3 \quad$ RISKS}

The Project Risk List (Table 5-1) identifies risks (see Section 6.5.3 for a more detailed discussion of the risk analysis methods and results) and handling methodologies associated with the risks. Handling actions have been incorporated in the baseline budget and schedule and have reduced risk to the point that all residual risk can now be assumed by the project. Many of the greatest risks to the project have been identified through key assumptions, as seen in Section 5.1, and are excluded from the risk analysis and risk list. Enabling assumptions as seen in Section 5.2 are referenced on Table 5-1 to show the relationship between the enabling assumptions and the risk statement. For summary results of the risk analysis performed in conjunction with creation of the risk list, see Section 6.5.3.

Risk lists are dynamic in nature. As a program progresses, new risks are identified, others are closed, and still others must be re-addressed because of changing circumstances. It will be the responsibility of the program to manage the critical risk list and modify it as the project progresses.

Table 5-1. 244-AR Vault Interim Stabilization Project Risk List. (3 Sheets)

\begin{tabular}{|l|l|l|}
\hline Risk Event & \multicolumn{1}{|c|}{ Risk Title } & \multicolumn{1}{|c|}{ Risk Statement } \\
\hline 670.DAA-R01 & Liquid Level Change & $\begin{array}{l}\text { If there is an intrusion to the facility after the waste has been } \\
\text { transferred to the DST system, but prior to the close of the } \\
\text { project, then there is a significant impact to the cost and } \\
\text { schedule to reconfigure the pumping system, consolidate, } \\
\text { sample and analyze the waste and perform the additional } \\
\text { transfer. }\end{array}$ \\
\hline 670.DAA-R02 & Critical Resource Availability & $\begin{array}{l}\text { If critical resources are not available when needed, then } \\
\text { delays will result. }\end{array}$ \\
\hline 670.DAA-R03 & $\begin{array}{l}\text { Non-Safety Employee Safety } \\
\text { Issues }\end{array}$ & $\begin{array}{l}\text { If an unanticipated employee issue occurs, then there will be } \\
\text { costs incurred and schedule delays. }\end{array}$ \\
\hline 670.DAC-R02 & 244-AR Notices of Construction & $\begin{array}{l}\text { If the regulator imposes unanticipated permit conditions } \\
\text { activities are identified, then additional NOC permits may be } \\
\text { required. } \\
\text { modifications may be required to the design of the system. }\end{array}$ \\
\hline 670.DAC-R03 & 244-AR Notices of Construction & $\begin{array}{l}\text { If the 244-AR work does not commence within } 18 \text { months of } \\
\text { the approval date of the NOC, then a new approval will be } \\
\text { required. }\end{array}$ \\
\hline 670.DAC-R04 & 244-AR Notices of Construction & $\begin{array}{l}\text { If the regulators do not accept PTE calculations without tank } \\
\text { specific head space sample data, then Vapor space sampling } \\
\text { may be required to support the NOC submittal and approval. }\end{array}$ \\
\hline
\end{tabular}


Table 5-1. 244-AR Vault Interim Stabilization Project Risk List. (3 Sheets)

\begin{tabular}{|c|c|c|}
\hline Risk Event & Risk Title & Risk Statement \\
\hline 670.DAC-R05 & 244-AR Notices of Construction & $\begin{array}{l}\text { If the Air Operating Permit is approved and mandatory } \\
\text { public review and comment periods for NOC approval come } \\
\text { into play, then there could be lengthy delays in NOC } \\
\text { approvals. }\end{array}$ \\
\hline 670.DAC-R06 & $\begin{array}{l}\text { Single Shell Part A Permit } \\
\text { Modification }\end{array}$ & $\begin{array}{l}\text { If regulators require additional public review or a type } 2 \text { or } 3 \\
\text { modification, then there could be significant delays to the } \\
\text { schedule. }\end{array}$ \\
\hline 670.DAC-R07 & Part B Permit Modification & $\begin{array}{l}\text { If the Part B Permit is approved, then additional limitations } \\
\text { could be imposed that would impact the cost and schedule of } \\
\text { transferring waste to a DST. }\end{array}$ \\
\hline 670.DAD-R01 & $\begin{array}{l}\text { Technical Inconsistency/ } \\
\text { Differences Between Licensing } \\
\text { and Design }\end{array}$ & $\begin{array}{l}\text { If the Authorization Basis amendment is not consistent with } \\
\text { the technical and engineering designs, then the amendment } \\
\text { would not support the removal of pumpable liquids from the } \\
\text { vault. This could cause rework of the amendment or } \\
\text { significant last-minute design changes or untenable controls. }\end{array}$ \\
\hline 670.DAD-R02 & $\begin{array}{l}\text { Funding for Tier } 2 \text { and Tier } 3 \\
\text { Reviews }\end{array}$ & $\begin{array}{l}\text { If the customer decides to have a more extensive Tier } 2 \\
\text { review than presently expected or requires a Tier } 3 \text { review, } \\
\text { then it is possible that the project will be over budget by the } \\
\text { amount of the cost of the review. }\end{array}$ \\
\hline 670.DAE-R01 & Low Priority & $\begin{array}{l}\text { It is possible that DOE may consider the review of the } \\
\text { amendment application low priority and delay the process. }\end{array}$ \\
\hline 670.DAF-R01 & Sole Source Procurement & $\begin{array}{l}\text { If sole procurement is not allowed, then schedule delays are } \\
\text { possible. }\end{array}$ \\
\hline 670.DAG-R0I & Mock-Up Location & $\begin{array}{l}\text { If the cold test facility is not available then an alternate } \\
\text { location will need to be found. This would cause schedule } \\
\text { delays. }\end{array}$ \\
\hline 670.DAH-R01 & Test site is not available & $\begin{array}{l}\text { Test site availability may impact schedule for set up and } \\
\text { testing and eventual transfer of liquids from } 244-\mathrm{AR} \text {. }\end{array}$ \\
\hline 670.DAJ-R01 & $\begin{array}{l}\text { PPE Requirements for } \\
\text { Stabilization Activities }\end{array}$ & $\begin{array}{l}\text { If airborne contamination levels cannot be controlled, then } \\
\text { schedule extensions and PPE costs would be incurred. }\end{array}$ \\
\hline 670.DAK-R01 & Excavation Permit & $\begin{array}{l}\text { If the underground transfer line cannot be installed, then an } \\
\text { above ground transfer line would be needed. This would } \\
\text { require different material to perform the work. }\end{array}$ \\
\hline 670.DAK-R02 & Additional Drop Legs and Pumps & $\begin{array}{l}\text { If liquid is found in the sumps in Cell } 1 \text { and } 2 \text { or the failed } \\
\text { equipment storage tubes, then additional drop legs and } \\
\text { pumps must be fabricated and installed. }\end{array}$ \\
\hline 670.DAK-R03 & Abrasive Water Jet & $\begin{array}{l}\text { If adequate access cannot be achieved to breach the tank } \\
\text { tops, then an alternate method of removing the liquid from } \\
\text { the tanks would have to be utilized. This would cause major } \\
\text { schedule delays and cost escalations. }\end{array}$ \\
\hline 670.DAM-R01 & Start up and Test Equipment & $\begin{array}{l}\text { Open items in preparation for testing may result in schedule } \\
\text { delays and increase in cost. }\end{array}$ \\
\hline 670.DAN-R01 & Inadequate Review Process & $\begin{array}{l}\text { If the project fails to pass the readiness assessment, then } \\
\text { there could be significant delays in schedule and additional } \\
\text { costs incurred by the project. }\end{array}$ \\
\hline
\end{tabular}


Table 5-1. 244-AR Vault Interim Stabilization Project Risk List. (3 Sheets)

\begin{tabular}{|c|c|c|}
\hline Risk Event & Risk Title & Risk Statement \\
\hline 670.DAP-R01 & Process Control Plan & $\begin{array}{l}\text { Plans for this activity do not include a process control plan. } \\
\text { If it is deemed necessary when this activity is actually done, } \\
\text { then it will not be funded or scheduled. The correct } \\
\text { sequence of consolidation must be performed, perhaps in a } \\
\text { process control plan. }\end{array}$ \\
\hline 670.DAP-R02 & $\begin{array}{l}\text { Additional Samples may be } \\
\text { Necessary }\end{array}$ & $\begin{array}{l}\text { If the waste must have compatibility assessment for internal } \\
\text { movement, then additional sampling must be added. } \\
\text { Additional samples will be needed, as all waste can not be } \\
\text { consolidated in a single tank, so that multiple transfers out } \\
\text { will be necessary. }\end{array}$ \\
\hline 670.DAQ-R01 & Amount of Analysis & $\begin{array}{l}\text { If approved tank (AY-102) cannot be used, then additional } \\
\text { analysis or alternate tank will be required. The amount of } \\
\text { analysis will depend on which tank the waste is sent to. A } \\
\text { glass feed tank takes more analysis. The volume of the } \\
\text { sample also changes. }\end{array}$ \\
\hline 670.DAQ-R02 & Toxic Chemicals Present & $\begin{array}{l}\text { If the analysis of the waste finds the presence of or elevated } \\
\text { levels of elements which restrict their transfer to the DST } \\
\text { system, then the project cost would increase and the schedule } \\
\text { duration would increase pending disposition of the waste and } \\
\text { resulting impacts to the permits. }\end{array}$ \\
\hline 670.DAR-R01 & Not Going to AY-102 & $\begin{array}{l}\text { The current route from diversion box AR-151 is to AY-102. } \\
\text { If another tank is chosen, then the impact could be to require } \\
\text { manufacturing and/or installing new jumpers to establish a } \\
\text { different route. The interconnected pipelines will add } \\
\text { complexity to the monitoring requirements during pumping. }\end{array}$ \\
\hline 670.DAV-R01 & $\begin{array}{l}\text { Isolation of Below Grade } \\
\text { Structures }\end{array}$ & $\begin{array}{l}\text { If the concrete encasement and the below grade structures } \\
\text { must be isolated, then additional cost and schedule delays } \\
\text { will result. }\end{array}$ \\
\hline 670.DAY-R01 & ORP Concurrence & $\begin{array}{l}\text { If regulators require additional NOC permits, or new } \\
\text { activities are identified, then additional delays will be } \\
\text { required. }\end{array}$ \\
\hline 670.DAY-R02 & ORP Concurrence & $\begin{array}{l}\text { If the regulator imposes unanticipated permit conditions } \\
\text { during the permitting process, then additional designs or } \\
\text { modifications may be required to the design of the system. }\end{array}$ \\
\hline 670.SCH-R01 & $\begin{array}{l}\text { Additional Cost of Program } \\
\text { Management }\end{array}$ & $\begin{array}{l}\text { If there are schedule delays, then management costs will be } \\
\text { incurred. } \\
\text { Note: This "psuedo" risk was added to reflect the dollar cost } \\
\text { of program management due to any extension of the project } \\
\text { caused by risks. The likelihood data is already factored into } \\
\text { the consequence numbers. }\end{array}$ \\
\hline
\end{tabular}

Note: This list documents the identified project risks. Some of these risks are beyond the control of the project and must be accepted at face value. These risks have been assumed by the project. Impacts of the remaining risks were reduced or eliminated by adding mitigating actions to the project baseline. These mitigating actions will reduce the risks to a level that can be assumed by the project. The allowance from the risk analysis is established to cover the assumed risk.

DOE = U.S. Department of Energy

DST $=$ double-shell tank

NOC $=$ Notice of Construction
PPE = personnel protective equipment

$\mathrm{PTE}=$ potential to emit 
RPP-5635 REV 0

This page intentionally left blank. 


\subsection{PROJECT BASELINE}

\subsection{PLANNING PROCESS}

In response to Performance Incentive (PI) ORP3.3.1, a technical task team was assembled in the first quarter of FY 2000 to evaluate options for interim stabilizing the 244-AR vault in preparation for turnover for final disposition and closure. The team proposed a preferred approach to stabilize the vault and perform intrusion prevention and isolation.

Building on the work performed by the technical task team, this project plan and the proposed project baseline were prepared and submitted as a recommended path forward. To define the baselines (technical scope, schedule, and cost), the RPP TBR-package planning process was used. The TBR packages document the project activity logic, scope definition and description; the detailed schedule; and the estimate of resources and their cost to complete the work.

To conduct the TBR-package planning process, multifunctional planning teams were formed with technically knowledgeable lead representatives and organizations responsible for performing the work. Organizations included Process Engineering; Nuclear Safety and Licensing; Operations; Technical Operations and Engineering; Business Management (scheduling and cost estimating); Environmental, Safety, Health, and Quality Assurance; and ORP. The team leads assigned had expertise in the type of work being planned to ensure that the work was properly scoped and scheduled. These planning teams also ensured that interfaces between performing organizations were identified for each activity and series of activities and that programs, projects, and operations work were integrated. Meetings were held with other RPP organizations and Site contractors to review potential work conflicts, resource integration, and required interfaces.

The planning teams were responsible for preparing all data contained in the TBR packages and schedule. The initial document prepared was the 244-AR Vault Interim Stabilization Project-level logic, which reflects the summary workscope and work flow for the Project (Section 6.3). Each activity on this logic represents a TBR package.

Once the project logic was completed, the work breakdown structure (WBS) for the Project was detailed (Section 6.2). All scope for this Project resides under the RPP WBS number 1.01.03., "Tank Farm Operation" (Project Baseline Summary [PBS]) TW03.

On the basis of the WBS and Project logic breakdowns, TBR packages then were prepared for each activity on the Project logic. TBR packages consist of the following:

- TBR control logs

- TBR narratives

- Primavera Project Planner ${ }^{\mathrm{TM}}-(\mathrm{P} 3)$ generated subactivity logic networks

- Subactivity cost-estimating input sheets (CEIS)

- P3-generated resource and cost-loading reports (pricing). 
The TBR narratives were prepared first, to fully define and document the technical (scope) description, assumptions, references, risks, requirements, drivers, and interfaces for each activity on the Project logic.

Using the TBR narratives, the planning teams then broke down each TBR activity into subactivity (and subtask) levels to define the detailed scope, logic, and activities. The subactivities then were evaluated to determine predecessor and successor activities, durations, and logic ties.

On the basis of the detailed subactivity scope and logic and other available information, CEISs then were prepared to define and document the subactivity (and subtask) scope, resources, basis of estimate, and assumptions at an executable task level.

Using data from the TBR packages, the planning teams then developed a detailed, integrated schedule in P3. The detailed subactivity logic networks and CEISs were used initially to define the activities in the schedule and their logic and resource loading. Logic between TBR activities was developed as required.

The first draft schedule prepared was unconstrained. This schedule then was constrained for selected critical resource availability, and the results were evaluated. This proposed schedule met the commitment dates to ORP and Ecology. The project plan uses a plan start date of October 1, 2000 for cost estimating purposes. The final detailed schedule (Section 6.4) was reviewed to verify scope (activities), activity durations, logic, and resource loading. The final schedule is task oriented, logic driven, and resource loaded. It is traceable to the Project logic, WBS, activity owners (performing organizations), and TBR package data including the detailed subactivity logic networks and CEISs.

The Project costs and staffing profile (Section 6.5) were generated from the final schedule. Resources were priced in P3 in accordance with approved forward-pricing labor rates and adders.

Based on the final schedule, the TBR packages were reviewed and approved as Rev. 0 by management and the performing organizations. The $\mathrm{P} 3$ cost and resource reports are included in the TBR packages.

\subsection{PROJECT WORK BREAKDOWN STRUCTURE}

Figure 6-1 shows the 244-AR Vault Interim Stabilization Project WBS. This Project WBS reflects all proposed work required to complete the project as scoped. This Project resides under RPP WBS number 1.01.03, "Tank Farm Operation." 
Figure 6-1. 244-AR Vault Interim Stabilization Project Work Breakdown Structure.

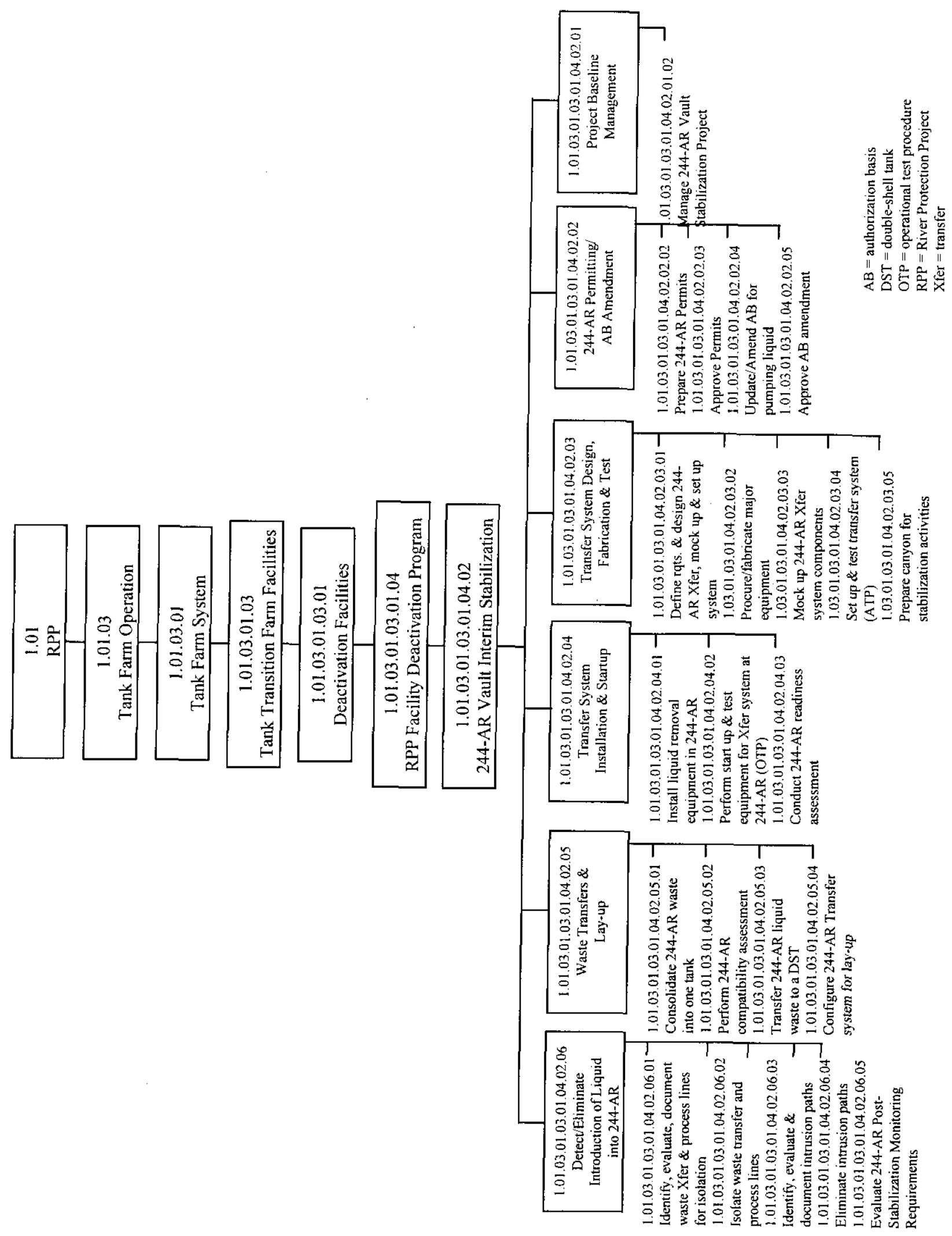


The WBS is used as a framework for scope definition, scheduling, budgeting, and management of the work. Activities in the Project logic and TBR packages reside in this WBS. Table 6-1 provides a crosswalk of the WBS to the Project logic activities.

Table 6-1. 244-AR Vault Interim Stabilization Project Work Breakdown Structure/Level 1 Logic Crosswalk

\begin{tabular}{|c|c|c|c|}
\hline WBS & WBS Title & Logic \# & Logic Title \\
\hline 1.1.3.1.3.1.4.2.1 & $\begin{array}{l}\text { Manage 244-AR Vault } \\
\text { Stabilization Project }\end{array}$ & 670.DAA & $\begin{array}{l}\text { Manage 244-AR Vault Interim Stabilization } \\
\text { Project }\end{array}$ \\
\hline \multirow[t]{4}{*}{1.1 .3 .1 .3 .1 .4 .2 .2} & \multirow{4}{*}{$\begin{array}{l}\text { 244-AR Permitting/AB } \\
\text { Amendment }\end{array}$} & 670.DAC & Prepare 244-AR permits \\
\hline & & 670.DAY & Approve permits \\
\hline & & 670.DAD & Update/Amend $\mathrm{AB}$ for pumping liquids \\
\hline & & 670.DAE & Approve AB amendment \\
\hline \multirow[t]{5}{*}{1.1 .3 .1 .3 .1 .4 .2 .3} & \multirow[t]{5}{*}{$\begin{array}{l}\text { Transfer System Design, } \\
\text { Fabrication and Test }\end{array}$} & 670.DAB & $\begin{array}{l}\text { Define requirements and design } 244-\mathrm{AR} \\
\text { transfer, mock up and set up systems }\end{array}$ \\
\hline & & 670.DAF & Procure /fabricate major equipment \\
\hline & & 670.DAG & Mock up 244-AR transfer system components \\
\hline & & 670.DAH & Set up and test transfer system (ATP) \\
\hline & & 670.DAJ & $\begin{array}{l}\text { Prepare canyon for interim stabilization } \\
\text { activities }\end{array}$ \\
\hline \multirow[t]{3}{*}{1.1 .3 .1 .3 .1 .4 .2 .4} & \multirow{3}{*}{$\begin{array}{l}\text { Transfer System } \\
\text { Installation and Startup }\end{array}$} & 670.DAK & Install liquid removal equipment in $244-\mathrm{AR}$ \\
\hline & & 670.DAM & $\begin{array}{l}\text { Perform start up and test equipment for } \\
\text { transfer system at 244-AR (OTP) }\end{array}$ \\
\hline & & 670.DAN & Conduct 244-AR readiness assessment \\
\hline \multirow[t]{4}{*}{1.1 .3 .1 .3 .1 .4 .2 .5} & \multirow{4}{*}{$\begin{array}{l}\text { Waste Transfers and } \\
\text { System Lay-up }\end{array}$} & 670.DAP & Consolidate 244-AR waste into one tank \\
\hline & & 670.DAQ & Perform 244-AR compatibility assessment \\
\hline & & 670.DAR & Transfer 244-AR liquid waste into a DST \\
\hline & & 670.DAS & Configure 244-AR transfer system for lay-up \\
\hline \multirow[t]{5}{*}{1.1 .3 .1 .3 .1 .4 .2 .6} & \multirow{5}{*}{$\begin{array}{l}\text { Detect/Eliminate } \\
\text { Introduction of Liquid } \\
\text { into } 244-\mathrm{AR}\end{array}$} & 670.DAT & $\begin{array}{l}\text { Identify, evaluate, document waste transfer } \\
\text { process lines for isolation }\end{array}$ \\
\hline & & 670.DAU & Isolate waste transfer and process lines \\
\hline & & 670.DAV & $\begin{array}{l}\text { Identify, evaluate and document intrusion } \\
\text { paths }\end{array}$ \\
\hline & & 670.DAW & Eliminate intrusion paths \\
\hline & & 670.DAX & $\begin{array}{l}\text { Evaluate } 244-A R \text { post-interim stabilization } \\
\text { monitoring requirements }\end{array}$ \\
\hline $\begin{array}{l}\text { AB }=\text { authoriz } \\
\text { ATP }=\text { acceptan } \\
\text { DST }=\text { double-s } \\
\text { OTP }=\text { operatio } \\
\text { WBS }=\text { work bre }\end{array}$ & $\begin{array}{l}\text { ion basis } \\
\text { e test plan/procedure } \\
\text { ell tank } \\
\text { al test procedure } \\
\text { kdown structure }\end{array}$ & & \\
\hline
\end{tabular}




\subsection{PROJECT LOGIC}

Appendix C shows the Project-level logic for the 244-AR Vault Interim Stabilization Project (drawing number RPP-5875). Development of the Project logic translates the Project mission requirements discussed in Section 2.0 into a sequence of activities and work flow necessary to achieve the mission objectives. The Project logic reflects the scope of work necessary to complete the Project.

The Project-level logic is traceable to and supports the RPP Mission Logic Level 0 (drawing number TWR-2086), which represents the entire scope of work necessary to achieve the RPP life-cycle mission. Traceability is maintained from the Level 0 Logic box activity number 67 , "Disposition Inactive Tank Facilities" through the decomposition of that activity (drawing number TWR-3981), to the 244-AR Vault Interim Stabilization Project-level logic by the use of consistent activity coding; box 67 becomes 670 .DAZ at the next level.

The Project-level logic reflects an assumed flow of the remaining work in accordance with a typical program and project mission life cycle (Section 2.7). The logic activities start with development of an interim stabilization project plan and finish with lay-up of the transfer system on completion of the work. While the Project-level logic identifies the project activities, work flow, and general scope, this logic is not a schedule, and specific logic ties, timing, and durations should not be inferred. Furthermore, all logic ties are not reflected at this level. This information is contained in the P3 detailed schedule (Section 6.4).

Each activity on the Project-level logic represents a TBR package. The TBR packages were developed to document the scope, estimates, and schedule data at the appropriate subactivity level of detail. The TBR package data then were used to develop the detailed P3 schedule. This process provides for traceability from the detailed P3 schedule, through the TBR packages, to the Project-level logic and finally to the Level 0 logic.

\subsection{PROJECT SCHEDULE}

On the basis of the planning process described in Section 6.1, the proposed detailed schedule was prepared (Figure 6-2). The schedule is formatted by WBS and TBR package subactivity breakdown. The schedule was developed from and is traceable to the WBS, Project-level logic, and TBR package data. The schedule reflects a data date of October 1,2000. All work scope required to complete the Project has been included in the schedule.

The schedule, prepared in P3, is task oriented, logic driven, and resource loaded. Activities and resources from the TBR package detailed subactivity logic networks and CEISs were loaded and priced in this P3 schedule to produce the cost and full-time-equivalent (FTE) staffing summaries found in Section 6.5. 


\section{RPP-5635 REV 0}

Figure 6-2. 244-AR Vault Interim Stabilization Project Schedule. (2 Sheets)

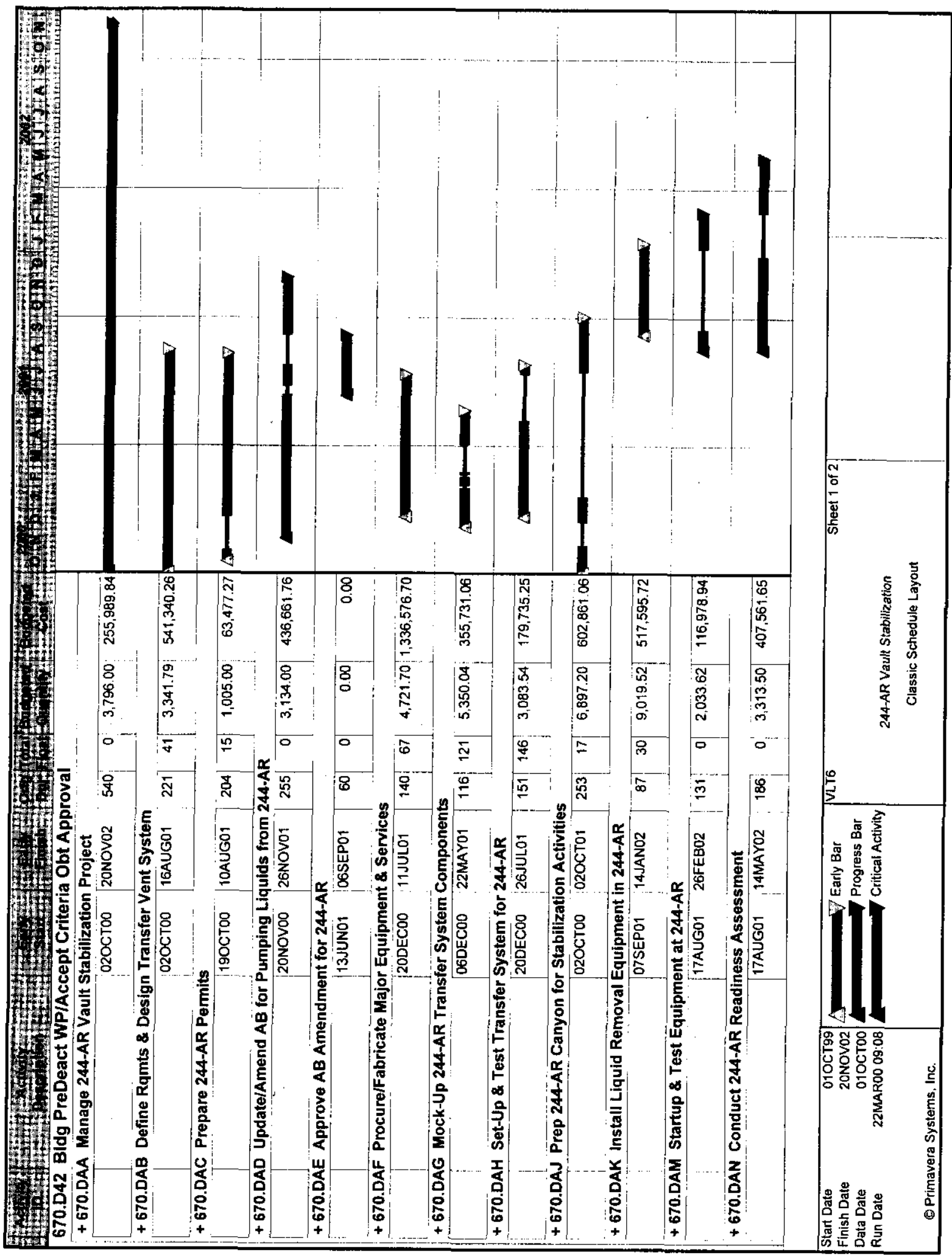


RPP-5635 REV 0

Figure 6-2. 244-AR Vault Interim Stabilization Project Schedule. (2 Sheets)

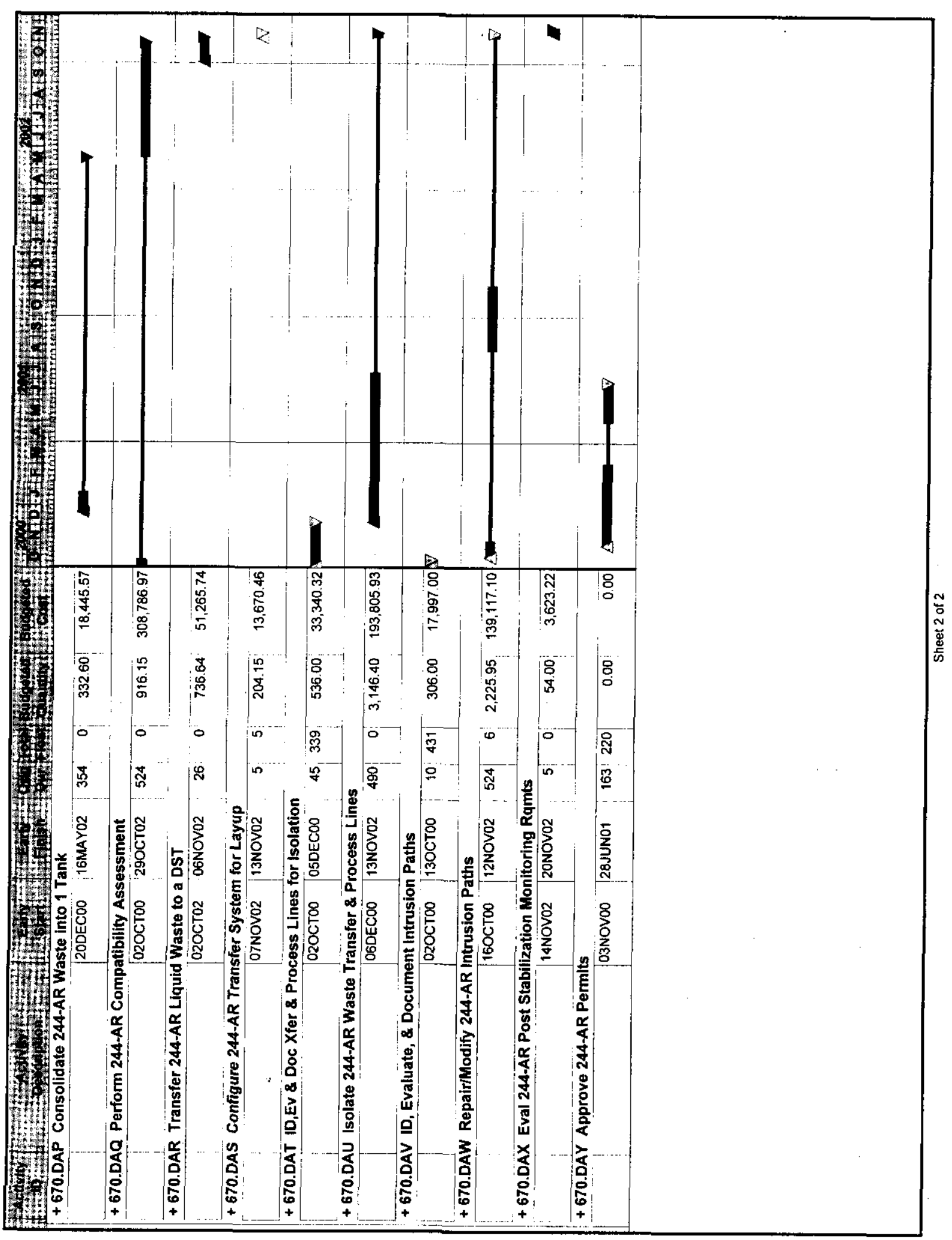


As discussed in Section 6.1, draft schedules were prepared during the TBR planning process (unconstrained and resource constrained). The proposed schedule reflects a target start date of October 1, 2000, which meets the target date for completing the Project by the agreed date of September 30, 2003. Key Project schedule completion dates, using the start date of October 1, 2000 , are as follows:

- Complete preliminary design of the transfer system

- Complete final design of transfer system

- ORP approval of the AB Amendment to pump liquids

- Install transfer system in 244-AR

- Complete Readiness Assessment

- Transfer liquids to a DST
December 19, 2000

August 16, 2001

September 6, 2001

January 14, 2002

May 14, 2002

November 6, 2002

The end date of the Project is November 20,2002, as reflected in schedule activity number 67DAXA.

See Section 6.5 .3 for the schedule risk analysis.

\subsection{COST AND BASELINE ANALYSIS}

\subsubsection{Cost by Work Breakdown Structure}

Table 6-2 summarizes the escalated costs by fiscal year and are estimated to complete the Project scope of work defined. Table 6-3 provides the unescalated costs by WBS for the activities contained and priced in the P3 detailed schedule.

Table 6-2. 244-AR Vault Interim Stabilization Project, Escalated Costs

by Fiscal Year with October 1, 2000, Start Date (\$000).

\begin{tabular}{|l|c|c|c|c|}
\hline & FY 2001 & FY 2002 & FY 2003 & Total \\
\hline Total Cost Unescalated & $4,031.0$ & $1,425.5$ & 138.0 & $5,594.5$ \\
\hline Total Escalation & 92.7 & 68.4 & 10.2 & 171.3 \\
\hline Total Escalated Cost & $4,123.7$ & $1,493.9$ & 148.2 & $5,765.8$ \\
\hline
\end{tabular}


Table 6-3. 244-AR Vault Interim Stabilization Project, Cost by

Work Breakdown Structure, Unescalated (\$000).

\begin{tabular}{|c|c|c|c|c|c|}
\hline \multirow{2}{*}{ WBS Number } & \multirow{2}{*}{ WBS Description } & \multicolumn{3}{|c|}{ Fiscal Year } & \multirow{2}{*}{ Total } \\
\hline & & 2001 & 2002 & 2003 & \\
\hline 1.01 .03 .01 .03 .01 .04 .02 .01 & \multicolumn{5}{|l|}{ Project Baseline Management } \\
\hline 1.01 .03 .01 .03 .01 .04 .02 .01 .02 & $\begin{array}{l}\text { Manage 244-AR Vault Interim Stabilization } \\
\text { Project }\end{array}$ & 119.0 & 119.5 & 17.5 & 256.0 \\
\hline 1.01.03.01.03.01.04.02.02 & \multicolumn{5}{|l|}{ 244-AR Permitting/AB Amendment } \\
\hline 1.01 .03 .01 .03 .01 .04 .02 .02 .02 & Prepare 244-AR Permits & 63.5 & & & 63.5 \\
\hline $1.01 .03 .01,03.01 .04 .02 .02 .03$ & Approve Permits & 0.0 & & & 0.0 \\
\hline $1.01 .03 .01,03.01 .04 .02 .02 .04$ & Update/Amend $A B$ for pumping liquids & 431.0 & 5.6 & & 436.6 \\
\hline 1.01 .03 .01 .03 .01 .04 .02 .02 .05 & Approve AB Amendment & 0.0 & 0.0 & & 0.0 \\
\hline 1.01.03.01.03.01.04.02.03 & \multicolumn{5}{|c|}{ Transfer System Design, Fabrication and Test } \\
\hline 1.01 .03 .01 .03 .01 .04 .02 .03 .01 & $\begin{array}{l}\text { Define requirements \& design } 244 \text {-AR transfer, } \\
\text { mock up \& set up system }\end{array}$ & 541.3 & & & 541.3 \\
\hline 1.01 .03 .01 .03 .01 .04 .02 .03 .02 & Procure/fabricate major equipment & $1,336.6$ & & & $1,336.6$ \\
\hline 1.01 .03 .01 .03 .01 .04 .02 .03 .03 & Mock up 244-AR transfer system components & 355.7 & & & 355.7 \\
\hline 1.01 .03 .01 .03 .01 .04 .02 .03 .04 & Set up \& test transfer system (ATP) & 179.7 & & & 179.7 \\
\hline 1.01 .03 .01 .03 .01 .04 .02 .03 .05 & Prepare canyon for interim stabilization activities & 600.5 & 2.3 & & 602.8 \\
\hline 1.01.03.01.03.01.04.02.04 & \multicolumn{5}{|l|}{ Transfer System Installation and Startup } \\
\hline $1.0 \mathrm{I} .03 .01 .03 .01 .04 .02 .04 .01$ & Install liquid removal equipment in $244-\mathrm{AR}$ & 8.5 & 509.1 & & 517.6 \\
\hline 1.01 .03 .01 .03 .01 .04 .02 .04 .02 & $\begin{array}{l}\text { Perform startup \& test equipment for transfer } \\
\text { system at 244-AR (OTP) }\end{array}$ & 40.2 & 76.8 & & 117.0 \\
\hline 1.01 .03 .01 .03 .01 .04 .02 .04 .03 & Conduct $244-\mathrm{AR}$ readiness assessment & 22.5 & 385.0 & & 407.5 \\
\hline 1.01.03.01.03.01.04.02.05 & \multicolumn{5}{|l|}{ Waste Transfers and Lay-up } \\
\hline 1.01 .03 .01 .03 .01 .04 .02 .05 .01 & Consolidate 244-AR waste into one tank & 12.5 & 6.0 & & 18.5 \\
\hline 1.01 .03 .01 .03 .01 .04 .02 .05 .02 & Perform 244-AR compatibility assessment & 6.8 & 285.2 & 16.8 & 308.8 \\
\hline 1.01 .03 .01 .03 .01 .04 .02 .05 .03 & Transfer 244-AR liquid waste to a DST & & & 51.3 & 51.3 \\
\hline 1.01 .03 .01 .03 .01 .04 .02 .05 .04 & Configure 244-AR transfer system for lay-up & & & 13.7 & 13.7 \\
\hline 1.01.03.01.03.01.04.02.06 & \multicolumn{5}{|c|}{ Detect/Eliminate Introduction of Liquid into 244-AR } \\
\hline 1.01 .03 .01 .03 .01 .04 .02 .06 .01 & $\begin{array}{l}\text { Identify, evaluate, document waste transfer \& } \\
\text { process lines for isolation }\end{array}$ & 33.3 & & & 33.3 \\
\hline 1.01 .03 .01 .03 .01 .04 .02 .06 .02 & Isolate waste transfer and process lines & 168.0 & & 25.8 & 193.8 \\
\hline 1.01 .03 .01 .03 .01 .04 .02 .06 .03 & Identify, evaluate \& document intrusion paths & 18.0 & & & 18.0 \\
\hline 1.01 .03 .01 .03 .01 .04 .02 .06 .04 & Eliminate intrusion paths & 93.9 & 36.0 & 9.3 & 139.2 \\
\hline 1.01 .03 .01 .03 .01 .04 .02 .06 .05 & $\begin{array}{l}\text { Evaluate } 244-\mathrm{AR} \text { post-interim stabilization } \\
\text { monitoring requirements }\end{array}$ & & ' & 3.6 & 3.6 \\
\hline 1.01 .03 .01 .03 .01 .04 .02 & $\begin{array}{l}\text { 244-AR Vault Interim Stabilization } \\
\text { Project total }\end{array}$ & $4,031.0$ & $1, \mathbf{4 2 5 . 5}$ & 138.0 & $5,594.6$ \\
\hline
\end{tabular}

The costs in Tables 6-2 and 6-3 are consistent with the detailed P3 schedule of activities and are supported by the TBR package data including the CEIS resources, budget quantities, and basis of estimate. 
Pricing for the work was performed in the schedule by means of a P3 resource-rate library based on approved ORP guidance. The labor and nonlabor rates in the library are fully burdened with the applicable adders except for escalation. The rate guidance is issued by FHU/ORP.

The Project costs have been escalated per the latest DOE and CHG guidance for FY 2000 multi-year work plan (MYWP) forward pricing. The escalation factors are effective starting in FY 2001, because the pricing rates are based on FY 2000 dollars. The annual and cumulative escalation factors used for FY 2001, FY 2002, and FY 2003 are 2.3\%, 4.8\%, and 7.4\%.

See Section 6.5 .3 for the cost risk analysis.

\subsubsection{Labor Resources by Work Breakdown Structure}

Table 6-4 summarizes the full-time-equivalent labor necessary to complete the Project scope of work as defined in the P3 detailed schedule. This table, generated in P3, is based on work-hour resource loading by Common Occupational Classification System and activity in the CEIS. The work hours are based on the realization calendar of 1,812 hours per year. The schedule is based on a 40-hour work week except for the waste-pumping activities, which require multiple shifts for a period of days.

Existing staff availability and ramp-up was evaluated as part of the TBR planning process and TBR approvals, which include verifying that the personnel resource loadings and schedule are appropriate.

Table 6-4. 244-AR Vault Interim Stabilization Project, Full-Time Equivalents By Work Breakdown Structure. (2 Sheets)

\begin{tabular}{|c|c|c|c|c|}
\hline \multirow{2}{*}{ WBS Number } & \multirow{2}{*}{ WBS Description } & \multicolumn{3}{|c|}{ Full Time Equivalents } \\
\hline & & FY 2001 & FY 2002 & FY 2003 \\
\hline 1.01 .03 .01 .03 .01 .04 .02 .01 & \multicolumn{4}{|l|}{ Project Baseline Management } \\
\hline 1.01 .03 .01 .03 .01 .04 .02 .01 .02 & $\begin{array}{l}\text { Manage 244-AR Vault Interim Stabilization } \\
\text { Project }\end{array}$ & .97 & .98 & .14 \\
\hline 1.01.03.01.03.01.04.02.02 & \multicolumn{4}{|l|}{ 244-AR Permitting/AB Amendment } \\
\hline 1.01 .03 .01 .03 .01 .04 .02 .02 .02 & Prepare 244-AR permits & .55 & & \\
\hline 1.01 .03 .01 .03 .01 .04 .02 .02 .03 & Approve permits & ORP & & \\
\hline 1.01 .03 .01 .03 .01 .04 .02 .02 .04 & Update/Amend $\mathrm{AB}$ for pumping liquids & 1.69 & .04 & \\
\hline 1.01 .03 .01 .03 .01 .04 .02 .02 .05 & Approve $\mathrm{AB}$ amendment & ORP & & \\
\hline 1.01.03.01.03.01.04.02.03 & \multicolumn{4}{|c|}{ Transfer System Design, Fabrication and Test } \\
\hline 1.01 .03 .01 .03 .01 .04 .02 .03 .01 & $\begin{array}{l}\text { Define requirements \& design } 244-\mathrm{AR} \text { transfer, } \\
\text { mock-up \& set-up system }\end{array}$ & 1.84 & & \\
\hline 1.01 .03 .01 .03 .01 .04 .02 .03 .02 & Procure/fabricate major equipment & 2.61 & & \\
\hline 1.01 .03 .01 .03 .01 .04 .02 .03 .03 & Mock up 244-AR transfer system components & 2.95 & & \\
\hline 1.01 .03 .01 .03 .01 .04 .02 .03 .04 & Set up \& test transfer system (ATP) & 1.70 & & \\
\hline 1.01 .03 .01 .03 .01 .04 .02 .03 .05 & $\begin{array}{l}\text { Prepare canyon for interim stabilization } \\
\text { activities }\end{array}$ & 3.78 & .02 & \\
\hline
\end{tabular}


Table 6-4. 244-AR Vault Interim Stabilization Project, Full-Time Equivalents By Work Breakdown Structure. (2 Sheets)

\begin{tabular}{|c|c|c|c|c|}
\hline \multirow{2}{*}{ WBS Number } & \multirow{2}{*}{ WBS Description } & \multicolumn{3}{|c|}{ Full Time Equivalents } \\
\hline & & FY 2001 & FY 2002 & FY 2003 \\
\hline 1.01.03.01.03.01.04.02.04 & \multicolumn{4}{|c|}{ Transfer System Installation and Startup } \\
\hline 1.01 .03 .01 .03 .01 .04 .02 .04 .01 & Install liquid removal equipment in 244-AR & .08 & 4.90 & \\
\hline 1.01 .03 .01 .03 .01 .04 .02 .04 .02 & $\begin{array}{l}\text { Perform startup \& test equipment for transfer } \\
\text { system at } 244-A R \text { (OTP) }\end{array}$ & .38 & .74 & \\
\hline 1.01 .03 .01 .03 .01 .04 .02 .04 .03 & Conduct $244-\mathrm{AR}$ readiness assessment & .12 & 1.71 & \\
\hline 1.01.03.01.03.01.04.02.05 & \multicolumn{4}{|l|}{ Waste Transfers and Lay-up } \\
\hline 1.01 .03 .01 .03 .01 .04 .02 .05 .01 & Consolidate 244 -AR waste into one tank & .12 & .06 & \\
\hline 1.01 .03 .01 .03 .01 .04 .02 .05 .02 & Perform 244-AR compatibility assessment & .05 & .32 & .14 \\
\hline 1.01 .03 .01 .03 .01 .04 .02 .05 .03 & Transfer 244-AR liquid waste to a DST & & & .41 \\
\hline 1.01 .03 .01 .03 .01 .04 .02 .05 .04 & Configure 244-AR transfer system for lay-up & & & .11 \\
\hline 1.01.03.01.03.01.04.02.06 & \multicolumn{4}{|c|}{ Detect/Eliminate Introduction of Liquid into 244-AR } \\
\hline 1.01 .03 .01 .03 .01 .04 .02 .06 .01 & $\begin{array}{l}\text { Identify, evaluate, document waste transfer \& } \\
\text { process lines for isolation }\end{array}$ & .30 & & \\
\hline 1.01 .03 .01 .03 .01 .04 .02 .06 .02 & Isolate waste transfer and process lines & 1.52 & & .22 \\
\hline 1.01 .03 .01 .03 .01 .04 .02 .06 .03 & Identify, evaluate \& document intrusion paths & .17 & & \\
\hline 1.01 .03 .01 .03 .01 .04 .02 .06 .04 & Eliminate intrusion paths & .86 & .31 & .05 \\
\hline 1.01 .03 .01 .03 .01 .04 .02 .06 .05 & $\begin{array}{l}\text { Evaluate } 244-\mathrm{AR} \text { post-interim stabilization } \\
\text { monitoring requirements }\end{array}$ & & & .03 \\
\hline 1.01.03.01.03.01.04.02 & $\begin{array}{l}\text { 244-AR Vault Interim Stabilization } \\
\text { Project - total full-time-equivalents }\end{array}$ & 19.70 & 9.08 & 1.11 \\
\hline
\end{tabular}

$\mathrm{ATP}=$ acceptance test plan/procedure

DST $=$ double-shell tank

OTP = operational test procedure

WBS $=$ work breakdown structure

\subsubsection{Baseline Risk Analysis}

Cost and schedule analyses were performed to identify the total budget and schedule duration required to complete the planned 244-AR Vault Interim Stabilization Project workscope. Inputs to the risk analyses included the cost and schedule data for planned activities and associated risks that result in potential impacts to the project.

These risks were analyzed to identify and quantify project risks and variability in the estimated cost and durations. The following discussion describes the process that was used to determine the cost and schedule impact of these uncertainties.

The risk analysis process involves capturing the variability on the budgeted and scheduled activities, as well as identifying the risks that are tied to enabling assumptions and other risks that could affect Project cost or schedule. 


\section{RPP-5635 REV 0}

The risk-analysis process begins with a review of the scope and cost (time and money) defined by the TBR packages and associated detailed schedules. All activities then are categorized into one of two categories (I and II below), and risks (see Table 5-1) are put into Category III.

- $\quad$ Category I - Fixed- an activity that is certain to occur or that is certain to be required and for which cost or schedule and scope are firmly known.

- Category II - Variable- an activity that is certain to occur or that is certain to be required but whose costs and schedule or quantity vary over some finite range.

- Category III - Uncertain- an event that may or may not happen or an activity that is not planned but may be required; if such an event occurs, it carries a cost or schedule impact that varies over some finite range.

Technical leads, operational personnel, estimators, and others with knowledge of the TBR package discuss the technical aspects with a risk facilitator. The facilitator leads the group through the process and supports the leads in filling out the risk sections of the TBR and input forms for the risk analysis.

During this process, participants are encouraged to think of actions or events that could occur within the limits of the workscope that would either decrease or increase the cost or schedule of the work to be performed in the TBR. Furthermore, participants are asked to identify any risks outside the defined scope of the TBRs that they believe are reasonable issues warranting further risk analysis (i.e., potential category III). These items are added to the risk list, which represents the identified project risk as seen in Table 5-1.

The risk analysts incorporate distribution-estimating techniques to develop the cost and schedule profile of the work. This data identifies the distribution of probable costs associated with each task. They are documented in terms of minimum, most likely, and maximum cost and schedule consequence ( $\$ 000$ or calendar days).

The analysis, which employs a Monte Carlo simulation, involves the assignment of random numbers to specific inputs in proportion to their consequence, drawing a sequence of random numbers and tabulating the associated outcomes. In this manner, a number of trials or a sequence of outcomes is generated that can be used to estimate the probabilities of expected values of a complex series of events.

The purpose of this simulation is to consider variation in the distribution of cost or schedule duration. The product of this analysis, known as an " $\mathrm{S}$ " curve, is first developed for all the "certain to occur" (Category I and II) items.

Because Category III items may or may not occur, additional data describing the likelihood of occurrence are required. As with data for Category I and II activities, this information represents a distribution of values. These data are added to the model, and a second curve is generated that includes Category I, II, and III (risk) data and represents the distribution of total cost and/or schedule. On the basis of this curve, budget or schedule (costs or completion dates) can be determined at selected probabilities. 
The analyses are based upon the assumption that all identified activities are performed to completion and thus, produce distribution curves of probable final cost and completion date. Each point of these curves represents either a dollar or time value with an associated probability that the final cost or completion date will not exceed that value. The project team selected the cost and completion date associated with the $80 \%$ probability point as the optimal value.

If the additional resource requirement identified from the " $\mathrm{S}$ " curve is determined to be too great or the additional risk is too high, mitigation actions can be developed and implemented to reduce the risk exposure. If such actions are approved, the costs associated with them are added to the Category I and II data (because they are then "certain to occur"), and the risk in the Category III data is either reduced or removed, on the basis of the calculated effectiveness of the mitigation action. During the analysis, risk mitigation plans were identified and, where feasible added to the project plan, offsetting larger risk exposure values.

The cost curve in Figure 6-3 represents the data for project-specific and project-variable cost (Categories I and II) and risk (Category III). This curve shows that the probability of success (where success is defined as completion of all identified tasks on-time and at-budget) based on the total Project budget of $\$ 5,594.5 \mathrm{~K}$ (unescalated) is near $0 \%$.

Figure 6-3. Category I, II, and III Project Cost Drivers for Completion of Project.

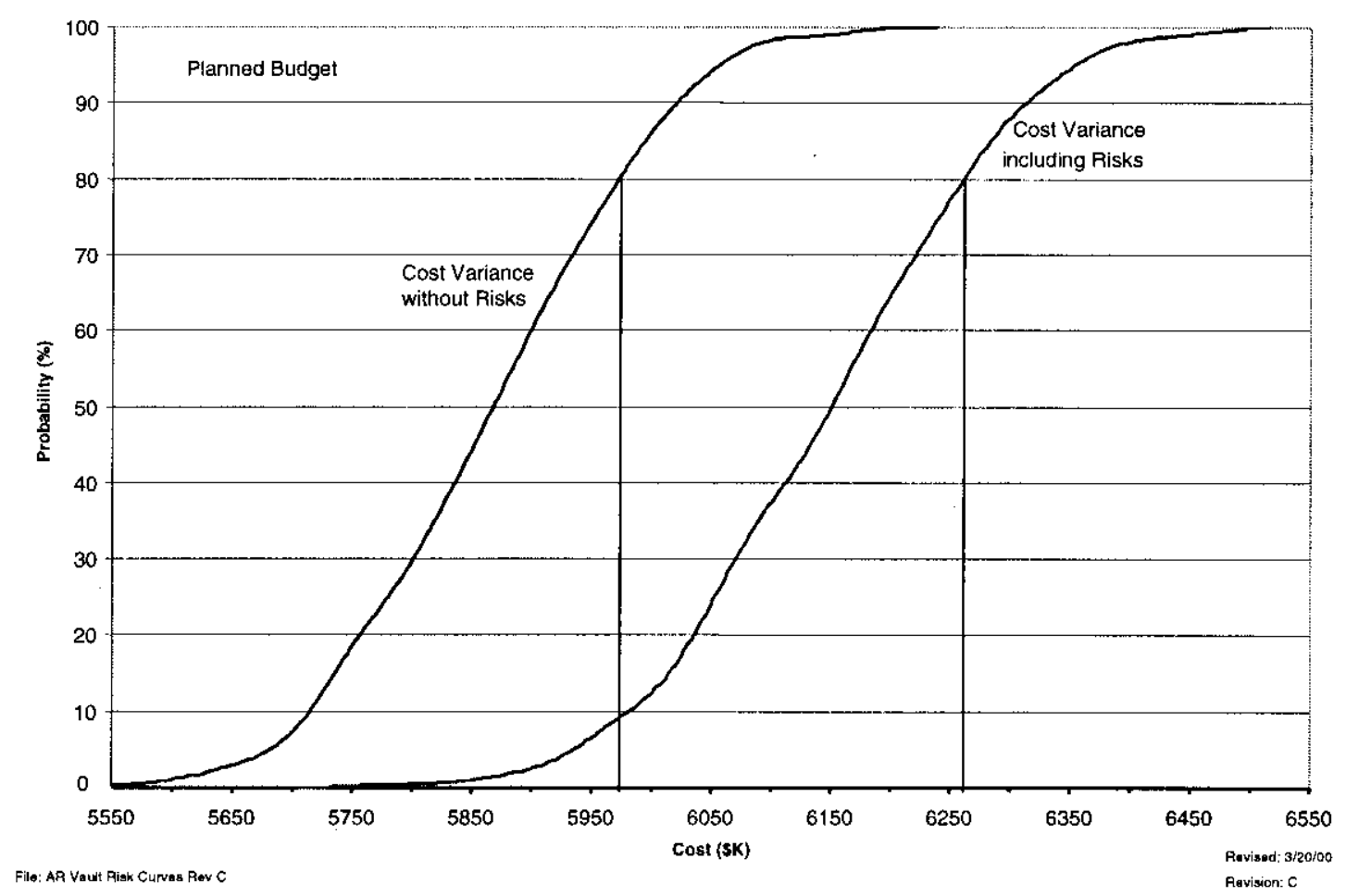

To achieve an $80 \%$ probability of success, an additional amount of $\$ 668 \mathrm{~K}$ must be added to the budget to pay for activities required when residual risks occur. This brings the total project cost to $\$ 6,262.5 \mathrm{~K}$ as seen in Table 6-5. 
The total Project Plan budget including risk mitigation dollars is $\$ 6,262.5 \mathrm{~K}$ (unescalated). This estimate comprises the total costs to complete the project, including costs for Operations activities, Technical Operations and Engineering activities, environmental permitting activities, AB support, installation, and risk mitigation.

The baseline cost by calendar year is shown in Table 6-5. This table identifies the cost variance and risk allowance by fiscal year.

Table 6-5. Escalated Costs by Fiscal Year Including Partial Risk Allowance (\$000).

\begin{tabular}{|l|c|c|c|c|}
\hline & FY 2001 & FY 2002 & FY 2003 & Total \\
\hline Total Cost Without Risk & $4,031.0$ & $1,425.5$ & 138.0 & $5,594.5$ \\
\hline Cost Variation & 269.2 & 86.0 & 21.8 & 377.0 \\
\hline Risk Allowance & 47.7 & 162.5 & 80.8 & 291.0 \\
\hline Subtotal & $4,347.9$ & $1,674.0$ & 240.6 & $6,262.5$ \\
\hline Escalation & 100.0 & 80.4 & 17.8 & 198.2 \\
\hline Total Project Cost & $4,447.9$ & $1,754.4$ & 258.4 & $6,460.7$ \\
\hline
\end{tabular}

The planned baseline schedule shows a Project duration of approximately 26 months (not including risk). When this data is analyzed in the Monte Carlo simulation, the " $\mathrm{S}$ " curve (Figure 6-4) shows that the completion of the Project by November 20, 2002, has a less than $20 \%$ probability of success. An adjustment of approximately 6 months was made to the schedule to bring the probability to $80 \%$; adjusting the Project completion date to May 27, 2003.

Figure 6-4. Category I, II, and III Project Schedule Drivers for Completion of Project.

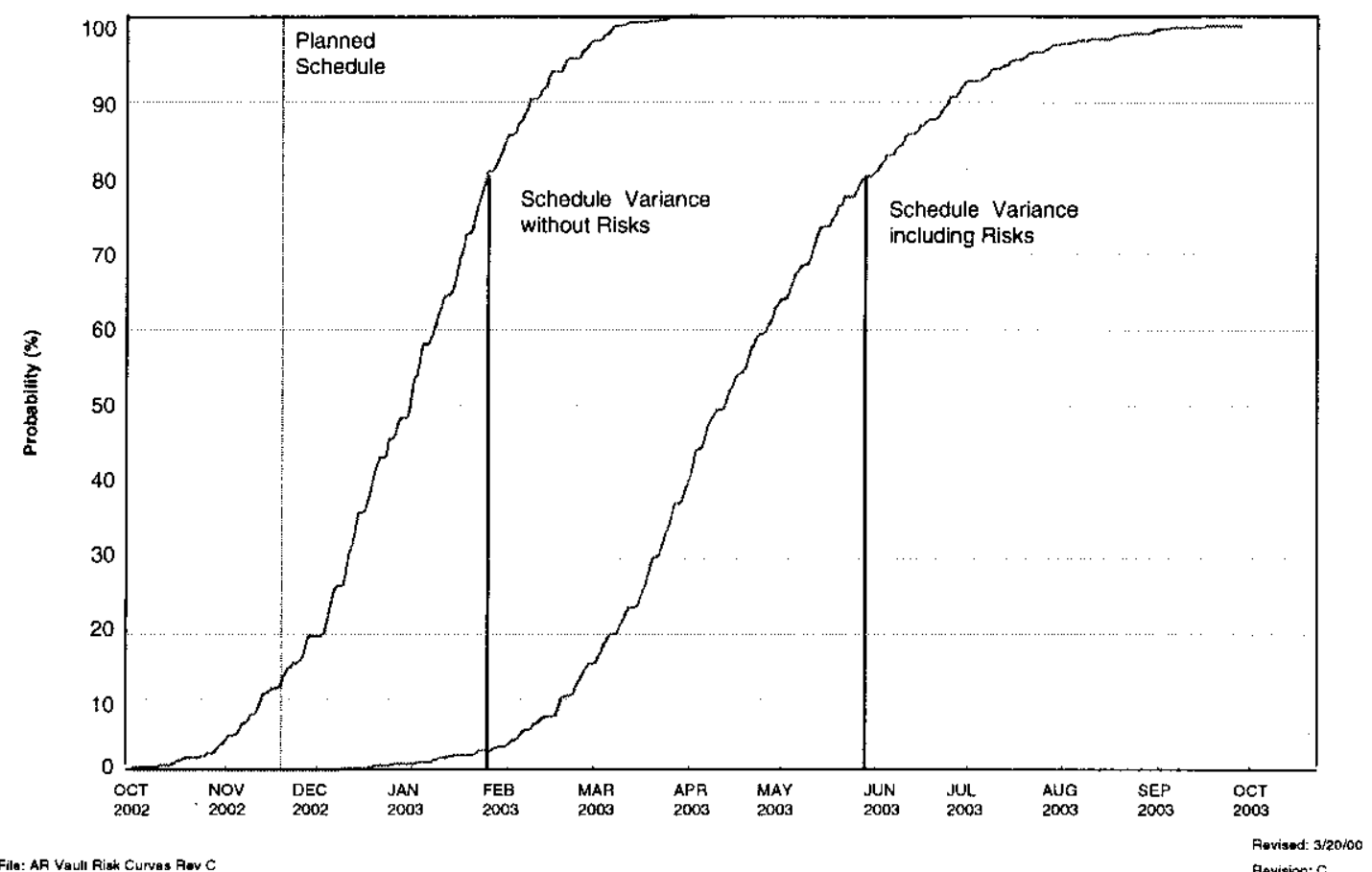




\section{RPP-5635 REV 0}

\subsection{PROCUREMENT ACTIVITIES}

Procurement activities for the 244-AR Vault Interim Stabilization Project are included in the project schedule and cost estimate. They include major equipment, other necessary material and equipment, and contracts. Table 6-6 is a summary of the labor, material, and contracts costs.

Table 6-6. Labor, Materials, and Contracts Costs (unescalated) (\$000).

\begin{tabular}{|l|c|c|c|c|}
\hline & FY 2001 & FY 2002 & FY 2003 & Total \\
\hline Labor & $2,171.9$ & 923.1 & 111.4 & $3,206.4$ \\
\hline Material & 925.7 & 30.5 & 6.2 & 962.4 \\
\hline Contracts & 849.1 & 193.1 & 3.5 & $1,045.7$ \\
\hline Other & $\mathbf{8 4 . 3}$ & 278.8 & 16.9 & 380.0 \\
\hline TOTAL & $\mathbf{4 , 0 3 1 . 0}$ & $\mathbf{1 , 4 2 5 . 5}$ & $\mathbf{1 3 8 . 0}$ & $\mathbf{5 , 5 9 4 . 5}$ \\
\hline
\end{tabular}


RPP-5635 REV 0

This page intentionally left blank. 


\subsection{TANK WASTE OPERATIONS}

Tank Waste Operations manages and directs, in a safe and efficient manner, operations, characterization, maintenance, and radiological control of tank activities pertaining to RPP permitted treatment, storage, and disposal facilities (Figure 7-1). The organization is flexible, and a matrixed management approach is used to support individual projects such as the 244-AR Project. Tank Farm Facilities Operations (TFFO) and the 244-AR Project are key to the success of the ORP project mission. Other RPP organizations supporting this mission and associated management concepts, policies, and processes are discussed in Appendix B, "Management Approach."

\subsection{TANK FARM FACILITIES OPERATIONS}

The TFFO is responsible for managing the 177 underground storage tanks (149 SSTs and 28 DSTs) in a safe and efficient manner that ensures compliance with DOE orders and federal, state, and local laws and regulations, and achieves the mission goals and objectives of DOE and ORP. The DST and SST shift managers are responsible for the safe execution of field activities. The shift managers report directly to the Shift Operations Manager, who in turn reports to the Vice President of Tank Waste Operations. A reporting structure is shown in Figure 7-2. Specifically, TFFO is responsible for the safe handling, separation, storage, and monitoring of highly radioactive liquid waste stored in the underground tanks.

The TFFO maintains a standard of performance for formal conduct of operations, maintenance, and radiological control by its personnel in accordance with the approved tank farm standards and requirements identification documents. Surveillance activities necessary to support the safe-storage mission, including the 244-AR Project, are performed to approved procedures. Specific responsibilities include the operations required to retrieve and transfer waste.

\section{$7.2 \quad$ POST-STABILIZATION OPERATIONS}

After the pumping operations are completed, the pumping system will be isolated and laid up. Pumps and associated hardware, including the transfer line, will be left in place. All lines will be flushed and isolated either inside or outside the facility canyon. The only installed equipment that will be removed as part of isolating the temporary transfer line will be the jumper in 151-AR valve pit. Other temporary equipment used to support waste transfer may be removed, requiring reconnection prior to future use. The transfer equipment will be left in place to meet future intrusion pumping requirements found in TPA Interim Milestone M-45-11. 


\section{RPP-5635 REV 0}

Figure 7-1. Tank Waste Operations Organization Chart.

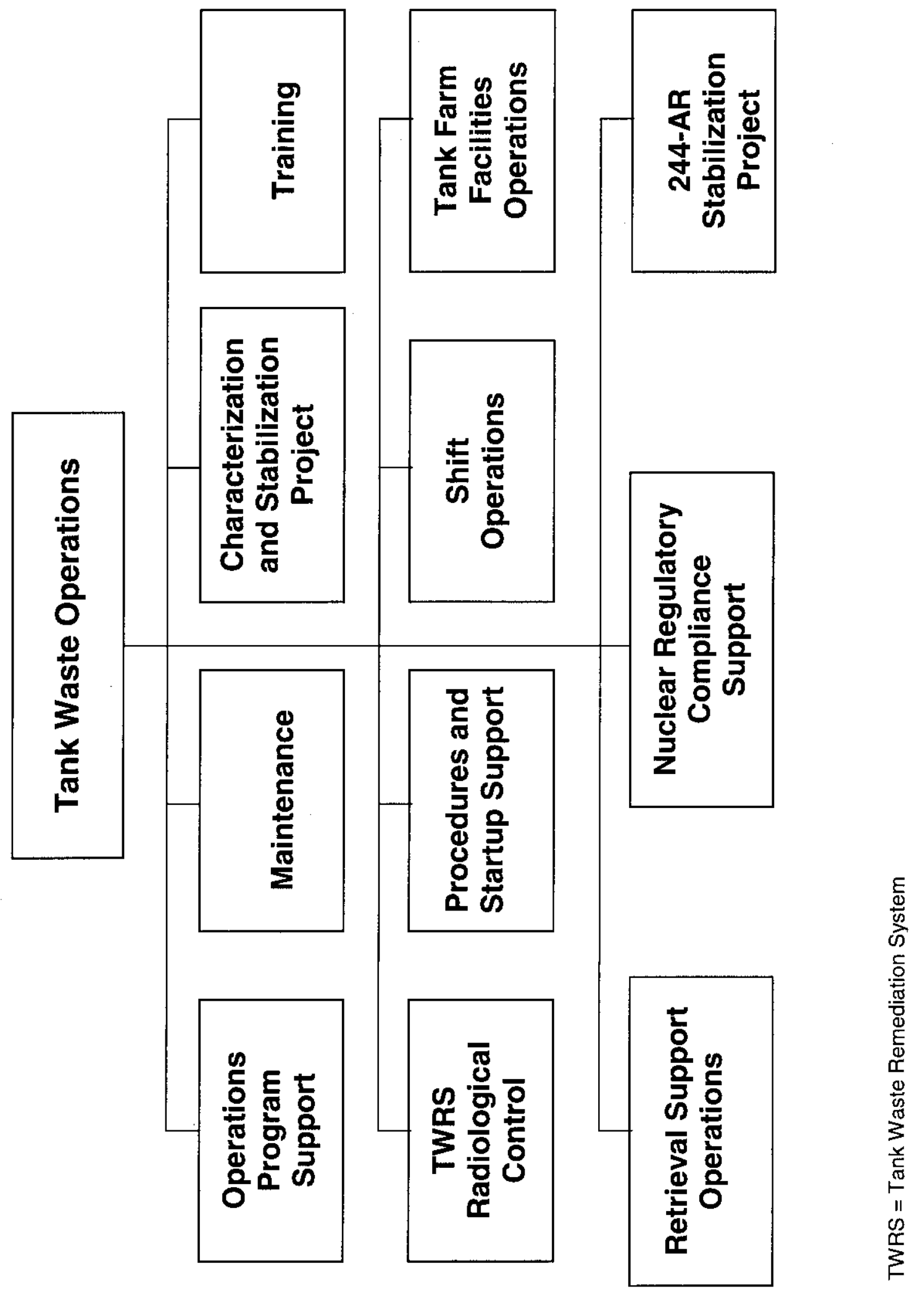


Figure 7-2. SY Farm Project Team.

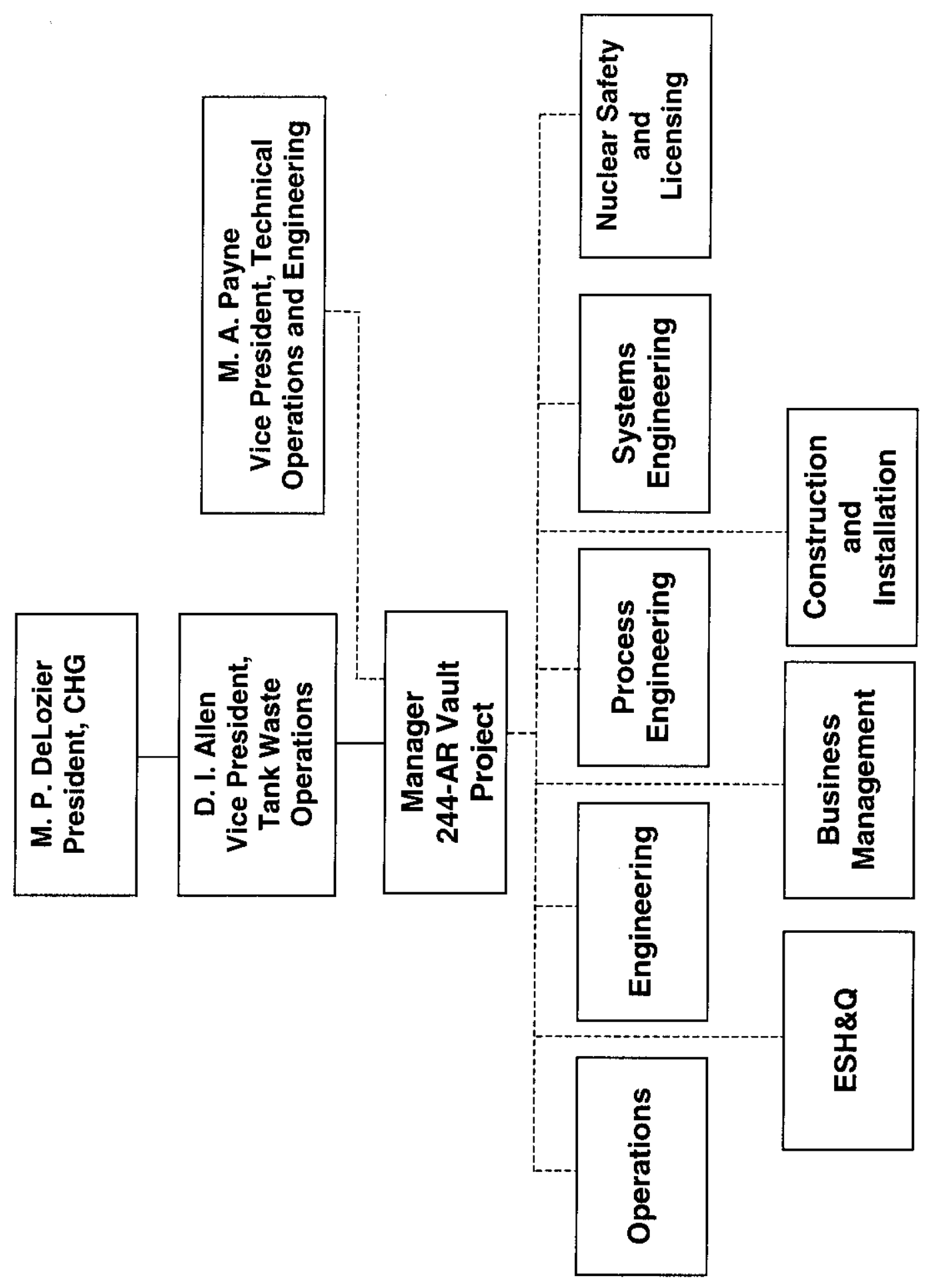

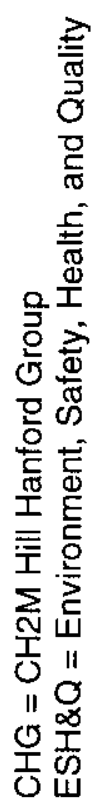


RPP-5635 REV 0

This page intentionally left blank. 
RPP-5635 REV 0

\subsection{REFERENCES}

NEPA National Environmental Policy Act of 1969

RCRA Resource Conservation and Recovery Act of 1976

SEPA State Environmental Policy Act

WAC Washington Administrative Code

D. J. Carrell, "Radioactive air emissions notice of construction use of a portable exhauster at 244-AR vault", DOE/RL-97-05, Rev. 2, Fluor Daniel Hanford, Inc., 1997

S. F. Agnew, "Hanford Tank Chemical and Radionuclide Inventories: HDW Model Rev 3.", LA-UR-96-858, May 1996

HNF-IP-0842, Vol. IV Section 4.27, Development Control Requirements.

DOE Order 5480.19, Conduct of Operations Requirements for DOE Facilities

HNF-IP-0842

DOE Order 4330.4B, Maintenance Management Program, Chapter 2, "Maintenance

Optimization for Essential Equipment Reliability

INPO 85-032, Preventive Maintenance, Good Practice MA-307

INPO-89-009, Plant Predictive Maintenance, Good Practice MA-316.

HNF-4453, Hazard Evaluation for 244-AR Vault, Bloom, J. W., 1999, Lockheed Martin Hanford Corporation

RPP-4779, Analysis of Postulated Flooding Accident in the 244-AR Vault, Himes, D. A., 1999, Lockheed Martin Hanford Corporation

DOE/EIS-0189 Final Environmental Impact Statement for the Tank Waste Remediation System

40 CFR 61 National Emission Standards for Hazardous Air Pollutants (NESHAPS)

WAC 173-400 General Regulations for Air Pollution Sources

WAC 173-460 Controls for New Sources of Toxic Air Pollutant

WAC 246-247 Radiation Protection-Air Emissions

DOE O 425.1A, "Startup And Restart Of Nuclear Facilities"

RLID 425.1 A, Attachment 8.1, "Startup/Restart Requirement Summary" 
RPP-5635 REV 0

This page is intentionally left blank. 
RPP-5635 REV 0

APPENDIX A

\section{REQUIREMENT MATRIX}


RPP-5635 REV 0

This page intentionally left blank. 


\section{APPENDIX A}

\section{REQUIREMENT MATRIX}

The 244-AR Vault Interim Stabilization Project Requirement Matrix was developed to guide the project team during the planning and design phase to support the successful completion of TPA Milestones M-45-11 and M-45-11A. Requirements were established to allow alternatives in the design options to be evaluated and to provide a quantified endpoint criteria for Milestone M-45-11. The column titled "Action to Meet the Requirement" contains a brief summary of the action and the measurable requirement for the action.

The column titled "Deliverable" includes the specific action required to document completion.

\begin{tabular}{|c|c|c|c|}
\hline Requirement & Source & Action to Meet the Requirement & Deliverable \\
\hline \multirow{2}{*}{$\begin{array}{l}\text { Remove pumpable } \\
\text { liquids from } \\
\text { 244-AR vault tanks }\end{array}$} & \multirow[b]{2}{*}{$M-45-11$} & $\begin{array}{l}\text { Tanks } 001 \mathrm{AR}, 002 \mathrm{AR} \text {. Reduce liquid to a level } \\
\text { equivalent to } 0.064 \mathrm{~m}(2.5 \mathrm{in} \text {.) of tank volume. } \\
\text { Estimated at } 1,834 \mathrm{~L}(485 \mathrm{gal}) \text {. }\end{array}$ & $\begin{array}{l}\text { Transfer summary sheet } \\
\text { with level detector } \\
\text { readings. }\end{array}$ \\
\hline & & $\begin{array}{l}\text { Tanks } 003 \mathrm{AR}, 004 \mathrm{AR} \text {. Remove liquid to the } \\
\text { depth volume equivalent to } 1 \mathrm{in.} \text { at the high side } \\
\text { of the sloped bottom of the tank. Estimated at } \\
458 \mathrm{~L}(121 \mathrm{gal}) \text {. }\end{array}$ & $\begin{array}{l}\text { Transfer summary sheet } \\
\text { with level detector } \\
\text { readings. }\end{array}$ \\
\hline $\begin{array}{l}\text { Remove pumpable } \\
\text { liquids from the } \\
\text { vault itself and its } \\
\text { associated sumps. }\end{array}$ & $M-45-11$ & $\begin{array}{l}\text { Remove liquids, if necessary, to a volume less } \\
\text { than the capacity of the sump and drain trench } \\
\text { (This volume would include any backflush water } \\
\text { for flushing the pump.) } \\
\text { Sump } 3=109.765 \mathrm{~L}(29 \mathrm{gal}) \\
\text { Sump } 1,2=106.68 \mathrm{~L} \text { ( } 35 \mathrm{gal})\end{array}$ & $\begin{array}{l}\text { Transfer summary sheet } \\
\text { with level detector } \\
\text { readings. }\end{array}$ \\
\hline $\begin{array}{l}\text { Isolate } 244-\mathrm{AR} \\
\text { vault }\end{array}$ & $M-45-11$ & $\begin{array}{l}\text { For all process liquids and waste transfer lines } \\
\text { connecting to the facility, place a mechanical } \\
\text { isolation in/on the line at the supply end and/or } \\
\text { on the } 244-\mathrm{AR} \text { vault end of the piping segment } \\
\text { entering the vault. }\end{array}$ & $\begin{array}{l}\text { Matrix listing lines, } \\
\text { type and location of } \\
\text { isolation, with } \\
\text { closed-out work } \\
\text { packages verifying } \\
\text { installations. }\end{array}$ \\
\hline $\begin{array}{l}\text { Provide for the } \\
\text { removal of } \\
\text { pumpable liquids } \\
\text { that may } \\
\text { accumulate in the } \\
\text { future }\end{array}$ & $M-45-11$ & $\begin{array}{l}\text { Leave pumping system in place and connected } \\
\text { with exception of the temporary equipment (e.g., } \\
\text { air supply, water supply, portable exhausters ). }\end{array}$ & $\begin{array}{l}\text { Issuance and approval } \\
\text { of procedure and } \\
\text { specification for } \\
\text { reconnection and } \\
\text { preparation for } \\
\text { operation of the system. }\end{array}$ \\
\hline $\begin{array}{l}\text { Install } \\
\text { Intrusion-preventio } \\
\mathrm{n} \text { mechanism as } \\
\text { may be necessary. }\end{array}$ & $M-45-11$ & $\begin{array}{l}\text { Mechanically seal or block all identified } \\
\text { intrusion routes. Methods may include vault } \\
\text { covers, foam, grout, cement, process blank, etc. } \\
\text { For some components, such as buried vaults and } \\
\text { concrete piping encasements, a white paper may } \\
\text { be created for specific concerns such as seepage. }\end{array}$ & $\begin{array}{l}\text { Matrix listing all } \\
\text { identified intrusion } \\
\text { paths, listing type and } \\
\text { location of intrusion } \\
\text { prevention or } \\
\text { evaluation document } \\
\text { number with closed-out } \\
\text { work packages } \\
\text { verifying installation. }\end{array}$ \\
\hline
\end{tabular}




\section{RPP-5635 REV 0}

\begin{tabular}{|l|c|l|l|}
\hline \multicolumn{1}{|c|}{ Requirement } & \multicolumn{1}{|c|}{ Source } & \multicolumn{1}{c|}{ Action to Meet the Requirement } & \multicolumn{1}{c|}{ Deliverable } \\
\hline $\begin{array}{l}\text { Establish periodic } \\
\text { liquid level } \\
\text { monitoring systems } \\
\text { for intrusion } \\
\text { detection before } \\
\text { final closure. }\end{array}$ & M-45-11 & $\begin{array}{l}\text { Provide instrumentation to detect a liquid } \\
\text { intrusion in each of the three sumps, capable of } \\
\text { detecting any intrusion that would exceed the } \\
\text { capacity of the sumps, with quarterly readings. }\end{array}$ & $\begin{array}{l}\text { Verify that monitoring } \\
\text { is in place in the three } \\
\text { sumps and is } \\
\text { operational (calibrated). }\end{array}$ \\
\hline
\end{tabular}


RPP-5635 REV 0

APPENDIX B

MANAGEMENT APPROACH

B-i 
RPP-5635 REV 0

This page intentionally left blank. 


\section{APPENDIX B}

\section{MANAGEMENT APPROACH}

Control and execution of the work scope included in the project baseline is aided by a structured management approach. This appendix summarizes the management concepts, policies, and processes used by the River Protection Project (RPP) organization and the Project team, including business management, engineering, the Integrated Safety Management System, decision management, risk management, configuration management, interface management and communication management.

\section{B1.0 BUSINESS MANAGEMENT}

Business management includes those principal activities necessary to establish and maintain the 244-AR Vault Interim Stabilization Project baseline. These activities include planning for, and providing input to, the mission scope and providing for schedule development, cost estimating, acquisition management, and performance monitoring.

\section{B1.1 PROJECT BASELINE DEVELOPMENT}

The integrated baseline development process is described in Section 6.0. The physical breakdown configuration, operational requirements, and technical requirements drive the work breakdown structure (WBS) (see Section 6.2), work definition, project logic, the supporting critical-path analyses, and baseline schedules. Once the work is defined, detailed schedules are developed and activities are resource loaded. Adjustments then are made to level the resources and meet the schedule and budget constraints imposed on the Project. The final scope, schedule, and the supporting cost estimates constitute the 244-AR Vault Interim Stabilization Project baseline.

\section{B1.2 WORK SCOPE MANAGEMENT}

Work scope management for the 244-AR Vault Interim Stabilization Project is performed through project logic (Section 6.3). This logic is an enhanced program evaluation and review technique chart that depicts, in a box and line format, the major activities, their relationships and dependencies, as well as predecessor and successor activities. The logic is derived from the Level 0 logic for the RPP and is maintained in a computer-based project-planning system (Primavera Project Planner ${ }^{1}$ or P3). Input to and modification of the P3 database are subject to configuration control, ensuring that the 244-AR Vault Interim Stabilization Project work cannot be altered without appropriate approval.

\footnotetext{
${ }^{1}$ Primavera Project Planner is a trademark of Primavera Systems, Inc.
} 
Activities in the 244-AR Vault Interim Stabilization Project logic are broken down into sets of logically linked tasks. These tasks are defined at a sufficiently low level to support defensible analyses of the duration and cost of each task. Technical basis review (TBR) packages are generated at this level. The TBR packages provide background summaries and identify enabling assumptions, responsible organizations, technical contacts for activities, interfaces and linkages to other activities, predecessor and successor activities, risks, and other information necessary to describe the essential attributes of each activity and its supporting tasks.

\section{B1.3 SCHEDULE MANAGEMENT}

The schedule for the 244-AR Vault Interim Stabilization Project is managed by integrating the detailed work schedules identified in the programmatic TBR packages. The work schedules are reviewed and adapted as needed to ensure consistency with programmatic direction. In addition, the 244-AR Vault Interim Stabilization Project schedules are aligned with the WBS and are subsequently integrated in the RPP multi-year work plan (MYWP).

\section{B1.4 COST MANAGEMENT}

Cost management for the 244-AR Vault Interim Stabilization Project will ensure that cost estimates are based on current plans or actual work performance and that the basis for cost estimates is consistent with the documented project scope and schedule baselines. Periodic reviews will be conducted on the financial status, and variance reports will be prepared. On the basis of reviews of these reports, responsible management will identify workarounds or other actions that may be required to eliminate variances or mitigate the effects of such variances.

\section{B1.5 WORK AUTHORIZATION}

Work authorization for the 244-AR Vault Interim Stabilization Project is authorized by an operation directive. The appropriate operation direction is approved by the CH2M HILL Hanford Group, Inc. (CHG), financial officer and the responsible Project Baseline Summary director.

\section{B1.6 SUBCONTRACTING}

Subcontracting for the 244-AR Vault Interim Stabilization Project occurs when offsite support is needed to accomplish required work. Task orders, specifications, statement of work, and/or acceptance criteria are developed to request subcontract work. This information is processed through the $\mathrm{CHG}$ Contracts organization for placement.

\section{B1.7 PERFORMANCE MEASUREMENT AND REPORTING}

Performance measures are developed at all management levels and are aimed at achieving optimal performance in cost, schedule, quality, and workforce productivity. Performance is measured against the plan, and all variances are monitored and controlled. Recovery plans are 
developed by the responsible manager for variances that exceed identified threshold tolerances. Responsible managers will monitor performance of internal support-service personnel and resolve deficiencies with the appropriate support service managers. The responsible managers also have the authority to reject costs erroneously charged to their work accounts. Table B-1 identifies the minimum levels of performance reporting for the 244-AR Vault Interim Stabilization Project.

Table B-1. Minimum Levels of Performance Reporting.

\begin{tabular}{|l|c|c|c|}
\hline $\begin{array}{c}\text { Work Breakdown } \\
\text { Structure Reporting } \\
\text { Level }\end{array}$ & $\begin{array}{c}\text { Cost-Account } \\
\text { Manager }\end{array}$ & Project Manager & $\begin{array}{c}\text { CHG } \\
\text { Management }\end{array}$ \\
\hline $\begin{array}{l}\text { Project Baseline } \\
\text { Summary }\end{array}$ & $\sqrt{ }$ & $\sqrt{ }$ & $\sqrt{ }$ \\
\hline Activity & $\sqrt{ }$ & $\sqrt{ }$ & $\sqrt{ }$ \\
\hline Cost Account & $\sqrt{ }$ & $\sqrt{ }$ \\
\hline Work Package & $\sqrt{ }$ & \\
\hline Task & $\sqrt{ }$ & & \\
\hline
\end{tabular}

Performance measures are reflected each month and are based on the actual costs and performance reported in the financial system. Performance also is measured through the use of numerous metrics including, but not limited to, budget/performance/cost profile and full-time equivalent plan-versus-use profile.

\section{B1.8 CONTINUOUS PROCESS IMPROVEMENT}

The 244-AR Vault Interim Stabilization Project Team is committed to the principle of continuous process improvement.

\section{B1.9 MANAGEMENT SYSTEMS}

The following sections describe systems and tools for information resource management and decision modeling use by the 244-AR Vault Interim Stabilization Project. Other key systems and processors are described in the remainder of Appendix B.

\section{B1.9.1 Information-Resource-Management Systems}

Much of the success of the 244-AR Vault Interim Stabilization Project management approach will rely on the ability to acquire and analyze budget information, cost information, and schedule information, and to use the Hanford Data Integrator 2000 System (HANDI 2000). The core business processes that HANDI 2000 will address are project management; financial 
management; supply management; and human resources, environmental, safety, and work management.

\section{B1.9.2 Management Tools}

The 244-AR Vault Interim Stabilization Project uses management tools to assist in decision making. The most popular of these are the scheduling and resource-planning tools for project planning, particularly the $\mathrm{P} 3$ application, which produces schedules with logic ties defining interdependence of the activities. This tool ensures that the resources are available to perform required work.

\section{B2.0 ENGINEERING}

The engineering process applied to the 244-AR Vault Interim Stabilization Project uses a systems approach. This process ensures that the technical baseline supports the identified problem needs and requirements. In this process the requirements are determined; the system is assessed; the existing technical baseline is verified; new hardware is designed, constructed/procured, installed and tested; existing hardware is checked, updated, and tested; and operations and maintenance are supported.

The engineering approach takes into account any modifications and maintenance to support the existing 244-AR vault that may be under way. The existing system and any ongoing activities are being assessed to ensure that they will perform the required functions and meet performance requirements. The systems focus on developing the functions, requirements, concepts, and integration of activities, whereas the engineering focus is on the existing technical baseline/system, design/construct/test, and operations and maintenance support.

\section{B2.1 SYSTEMS ENGINEERING}

Systems engineering is the fundamental tool for understanding and developing complex or first-of-a-kind systems throughout their life cycle. The systems engineering process is described in HNF-SD-WM-SEMP-002, Rev. 1, and in implementing procedures contained in HNF-IP-0842; it ensures that the technical baseline is defensible and integrated. This process has been implemented on the 244-AR Vault Interim Stabilization Project.

\section{B2.2 ENGINEERING PROCESS}

The engineering process is documented in HNF-1947. This plan describes the engineering process and the controls being put in place to support the technical baseline definition and to manage its control, evolution, and implementation. 


\section{B3.0 INTEGRATED SAFETY MANAGEMENT SYSTEM}

The objective of the Integrated Safety Management System (ISMS) is to facilitate safe work. The RPP organization is committed to performing work safely and efficiently and in a manner that ensures protection of the workers, the public, and the environment. Management of safety functions and activities is an integral aspect of RPP and is accomplished through the integration of safety management into all facets of work planning and execution. The ISMS establishes one Environmental, Safety, and Health Management System that integrates requirements into work planning and execution and identifies requirements reflecting DOE's commitment to a "standards-based" safety program and safety concepts.

The ISMS provides the mechanism for increased worker involvement in work planning (including the identification of hazards and environmental -impacts), analysis and control, and feedback/improvement processes. Effective implementation of the ISMS incorporates the best practices of, and supports the accomplishment of, the Voluntary Protection Program (VPP), the enhanced work planning/ Hanford Site occupational health process, and other similar environmental, safety, and health improvement initiatives.

HNF-1883, Section 9.3, provides additional detail on ISMS objectives and the roles and responsibilities of the integrated organizations supporting this effort. The following sections summarize the details and describe their relevance to the 244-AR Vault Interim Stabilization Project activities.

The Environmental, Safety, Health, and Quality Assurance (ESH\&Q); Radiological Control; Technical Operations and Engineering; and Nuclear Safety and Licensing organizations provide health and safety services to RPP. These organizations use the ISMS to integrate safety and health functions into work planning, execution, and follow-up. Programs are in place to oversee implementation of DOE Orders and Federal, state, and local laws and regulations; perform audits to verify compliance with regulatory and legal operational requirements; and provide guidance and policy direction for continuous improvement in the conduct of work.

\section{B3.1 ENVIRONMENTAL, SAFETY, HEALTH AND QUALITY ASSURANCE}

- Environmental. The Environmental Program facilitates RPP compliance by definition and oversight of the environmental regulatory requirements. HNF-1773 provides details on the Environmental Program processes, roles, and responsibilities. The 244-AR Vault Interim Stabilization Project activities are managed in accordance with HNF-1773.

- Safety and Health. The RPP Safety Program is a multidisciplined organization encompassing Industrial Safety, Industrial Hygiene, and Fire Protection. The Safety Program is implemented through numerous policies and procedures for Occupational Safety and Health and Fire Protection: HNF-SD-WM-HSP-002; HNF-IP-0842, Volume IX, Section 1.1; and RPP specific administrative and quality procedures. The 244-AR Vault Interim Stabilization Project activities use these procedures. Safety is integrated through the work planning process and the safety oversight function. 
- Quality Assurance. The "quality" management system for this activity is designed to achieve project control and meet the DOE customer's quality requirements as specified in 10 CFR 830.120. Additional customer quality requirements are derived from the Tri-Party Agreement. These quality requirements are transmitted to this activity through RPP-MP-0599, which identifies the guidance criteria to be used by the River Protection Project Contractors.

The interpretive authority for the customer's quality requirements is the Quality Assurance Center of Expertise. The Quality Assurance Center of Expertise has described the plan to achieve the customer's quality requirements in WHC-SP-1131.

The quality assurance policies and requirements for these activities are described in HNF-IP-0842, Volume XI, Sec. 1.1. This RPP Quality Assurance Program Plan includes an "Implementation Matrix" that identifies (1) the ten major elements of the requirements from DOE Order 414.1 and 10 CFR 830.120 ; (2) the sub-elements for each major element as specified in the Project Hanford Quality Assurance Program Description; and (3) the associated implementation documents cited in the matrix that constitute the RPP approach to achieving the requirements delineated in the Project Hanford Quality Assurance Program Description. These documents (most of which are procedures) control the quality assurance process for the entire RPP.

The Quality Assurance Program Plan is reviewed/revised annually to accommodate changes in requirements, activities, organization, or facilities. The 244-AR Vault Interim Stabilization Project activities fall under the Quality Assurance Program Plan and subordinate procedures.

\section{B3.1.1 Emergency Preparedness}

The Emergency Preparedness Program is an integral element of the ISMS; the program is described in WHC-IP-0971. The RPP Emergency Preparedness organization works in conjunction with the Sitewide Emergency Preparedness organization, which includes ORP and RPP team subcontractors. The RPP Project facility-specific requirements are identified and implemented by RPP Emergency Preparedness. The 244-AR Vault Interim Stabilization Project activities fall under the oversight of RPP Emergency Preparedness; these activities are covered by the current hazards assessment.

\section{B3.1.2 Radiological Control}

The Radiological Control Organization integrates safety and health functions into all phases of the RPP Project. The Hanford Site Radiological Control Manual (HSRCM-1, 1994) outlines the compliance program for 10 CFR 835, "Occupational Radiation Protection." The Radiological Control Organization implements this program through support and oversight of RPP project work, including the 244-AR Vault Interim Stabilization Project activities. This effort involves the generation of radiation work permits for relevant work and the assignment of radiological control technicians as appropriate. 


\section{B3.1.3 RPP Nuclear Safety and Licensing}

For the RPP Project, the nuclear safety authorization basis is developed and maintained by the Nuclear Safety and Licensing organization, reporting to the Technical Operations and Engineering director. This functional support group ensures consistency across all aspects of the ORP Project in terms of hazard identification; control development; safety structures, systems, and components identification specifications; authorization basis document preparation; associated DOE Order compliance; and approaches to dealing with technical uncertainty. The 244-AR Vault Interim Stabilization Project activities are evaluated for compliance with the authorization basis and other requirements through applicable ORP procedures.

\section{B4.0 DECISION MANAGEMENT}

Decision management provides traceability for making or changing decisions through the graded use of rigorous and methodical decision-making process. The 244-AR Project Management will implement the requirements of HNF-IP-0842, Volume X, Section 2.2, "RPP Systems Engineering Management Policy” (LMHC 1999); HNF-SD-WM-SEMP-002, Tank Waste Remediation System Engineering Management Plan (Peck 1998); and HNF-IP-0842, Volume IV, Section 2.7, "Decision Management" (LMHC 1999).

A graded approach to implementing this process is allowed for decisions of lesser impact. It is the responsibility of the designated decision maker to determine the degree to which the full decision-management process is applied to individual decisions. In such cases, 244-AR Project management will refer to HNF-IP-0842, Volume IV, Section 2.7, "Decision Management" (LMHC 1999), for specific guidance. At this time, no major decisions affect the 244-AR Project.

\section{B5.0 RISK MANAGEMENT}

The 244-AR Project has implemented a disciplined approach to project risk management to ensure that risks are identified and managed in a manner that eliminates or satisfactorily mitigates their impact. Risk-evaluation activities are embedded in the 244-AR Project Management processes and constitute a fundamental input to decision-making processes.

The ORP risk-management process is intended to reduce these risks to an acceptable level through risk assessment, analysis, and handling. Risks are intended to be communicated to the appropriate decision makers. The 244-AR Project risk management process is based on the requirements of HNF-IP-0842, Volume X, Section 2.2, "RPP Systems Engineering Management Policy" (LMHC 1999), and HNF-SD-WM-SEMP-002, Tank Waste Remediation Systems Engineering Management Plan (Peck 1998). These requirements cover risk assessment, risk analysis, and risk handling. 
The 244-AR Project will implement these requirements through HNF-IP-0842, Volume IV, Section 2.6, "Risk Management" (LMHC 1999). In response to this guidance, the 244-AR Project will perform the following.

- Identify and analyze potential technical, schedule, and cost risks for activities.

- Develop and maintain risk-management lists identifying the risks, their possible consequences, a measure of their relative importance, and the planned mitigation actions.

- Control and track completion of assigned risk-management mitigation activities.

- Communicate risk projects status through rollup to the appropriate management levels and cross communication with the appropriate client counterpart at each level.

The 244-AR Project TBR documentation (see Section 6.1) and the 244-AR Project Risk Management List (see Section 6.5) are the principal management tools used to identify, analyze, and track project risks and their related issues. TBR documents are developed for each key activity identified on the 244-AR Project Logic in Appendix C and incorporate an assessment of technical, schedule, and cost risks relating to that activity. Risk-management lists are used to compile, communicate, and track risks and actions taken to mitigate such risks.

\section{B6.0 CONFIGURATION MANAGEMENT}

Configuration management is an integral approach to controlling the technical, cost, schedule, and administrative information necessary to manage the 244-AR Project activities. It supports management of the 244-AR Project baseline by providing the mechanisms to identify, document, and control the functional and physical characteristics of the 244-AR Project products, particularly as changes are being made.

Configuration management focuses on five principal functions: configuration management, system management, configuration identification, configuration status accounting, change control, and configuration management assessments. Application of these functions is tailored to project requirements objectives to identify configuration items and configuration information to be controlled for each item and to control that information. Critical to this process is identification of the as-built configuration of project structures, systems, and components; the change-control thresholds for modifying this configuration; and the level of authority required for such changes.

The ORP configuration management policy and requirements are defined and described in HNF-1900, Tank Waste Remediation System Configuration Management Plan (Vann et al. 1998). The implementation process and mechanism used to establish and maintain configuration control are also described in HNF-1900. Specific mechanisms and requirements are addressed in detail by ORP procedures.

Tank Waste Operations has appointed a Tank Farm Facilities Operations configuration management representative who is responsible for identifying configuration items and 
configuration information, including the data in the ORP configuration program, and maintaining their traceability and consistency with source requirements. This effort covers the configuration management requirements for all activities with the Tank Farm Facilities Operations including those of the 244-AR Project.

\section{B7.0 INTERFACE MANAGEMENT AND CONTROL}

A major objective of interface management and control is to form agreements that allow organizations to design adjoining physical systems. Proper application of interface management and control processes results in structures, systems, and components that physically fit and function together without mismatch, omission, or interferences. Interface management and control also must be imposed when an organization interface is identified. Typically, the interfaces identified are with other internal ORP projects (e.g., Retrieval and Disposal, Tank Farm Facilities Operations, Interim Stabilization) or to external projects (e.g., Waste Management Project).

The requirement that project interfaces be identified, controlled, and integrated with other projects and activities is found in HNF-SD-WM-SEMP-002, TWRS Systems Engineering Management Plan (Peck 1998), and HNF-IP-0842, Volume IV, Section 2.8, "Interface Control" (LMHC 1999). The 244-AR Project will establish formal agreements with the performing organization, as needed. Performance against interface requirements will be monitored. The key interfaces affecting the 244-AR Project are addressed in Section 2.4.

Management of these interfaces is coordinated through the conduct of monthly, at minimum, meetings with the affected parties. The purpose of these meetings is to provide information on activities to all affected organizations, to discuss issues and conflicts, and to resolve any interface problems that may arise.

\section{B8.0 COMMUNICATION MANAGEMENT}

Project team meetings are the principal means of day-to-day communication for the 244-AR Project. Project activities are statused, issues are discussed, and action assignments are recorded and tracked. Project participants and representatives from ORP routinely attend and participate in these meetings.

Other forms of communication include the availability of electronic data, documentation, and briefings. Electronic communication is extensively utilized via the Hanford Local Area Network share drives. In addition, briefings to contractor senior management, DOE, ORP and the Washington State Department of Ecology are provided on an as-needed basis. 


\section{B9.0 REFERENCES}

\section{Code of Federal Regulations}

10 CFR 835, "Occupational Radiation Protection," Code of Federal Regulations, Title 10, Part 835 , as amended.

10 CFR 830.120, “Quality Assurance," Code of Federal Regulations, Title 10, Part 830.120, as amended.

\section{U.S. Department of Energy Orders}

DOE Order 414.1, Quality Assurance, U.S. Department of Energy, Washington D.C.

\section{Documents}

Borneman, L. E., 1998, Tank Waste Remediation System Environmental Program Plan, HNF-1773, Rev. 1, prepared by Lockheed Martin Hanford Corporation for Fluor Daniel Hanford, Inc., Richland, Washington.

Ecology et al., 1994, Hanford Federal Facility Agreement and Consent Order, Washington State Department of Ecology, U.S. Environmental Protection Agency, and U.S. Department of Energy, Olympia, Washington.

Freeman, D. V., 1998, TWRS Program Plan, HNF-1883, Rev. 1, prepared by Lockheed Martin Hanford Corporation for Fluor Daniel Hanford, Inc., Richland, Washington.

HANDI 2000 Project Execution Plan, HNF-1743, prepared by Lockheed Martin Hanford Corporation for Fluor Daniel Hanford, Inc., Richland, Washington.

HSRMC-1, 1994, Hanford Site Radiological Control Manual, Rev. 2, prepared for the U.S. Department of Energy, Richland Operations Office, by the Hanford Site Contractors, and managed by Pacific Northwest National Laboratory Records Management Office, Richland, Washington. Available on the Internet as DOE/RL-96-109, Hanford Radiological Control Manual, U.S. Department of Energy, Richland Operations Office, Richland, Washington, at http:/www.hanford.gov/docs/r196-109/a006t010.htm.

LMHC, 1999, TWRS Administration, HNF-IP-0842, prepared by Lockheed Martin Hanford Corporation for Fluor Daniel Hanford, Inc., Richland, Washington.

Mickle, G. D., 1995, Tank Farm Health and Safety Plan, HNF-SD-WM-HSP-002, Rev. 3A, prepared by Lockheed Martin Hanford Corporation for Fluor Daniel Hanford, Inc., Richland, Washington.

Peck, L. G., 1998, Tank Waste Remediation System Systems Engineering Management Plan, HNF-SD-WM-SEMP-002, Rev. 1, prepared by Lockheed Martin Hanford Corporation for Fluor Daniel Hanford, Inc., Richland, Washington. 


\section{RPP-5635 REV 0}

Rifaey, S. H., 1998, Tank Waste Remediation System Engineering Plan, HNF-1947, Rev.0, prepared by Lockheed Martin Hanford Corporation for Fluor Daniel Hanford, Inc., Richland, Washington.

Vann, J. M., E. R. Hamm, and R. D. Crisp, 1998, Tank Waste Remediation System Configuration Management Plan, HNF-1900, Rev. 0, prepared by Lockheed Martin Hanford Corporation for Fluor Daniel Hanford, Inc., Richland, Washington. 


\section{RPP-5635 REV 0}

This page intentionally left blank.

B-12 
RPP-5635 REV 0

APPENDIX C

244-AR LOGIC

C-i 


\section{RPP-5635 REV 0}

This page intentionally left blank.

C-ii 


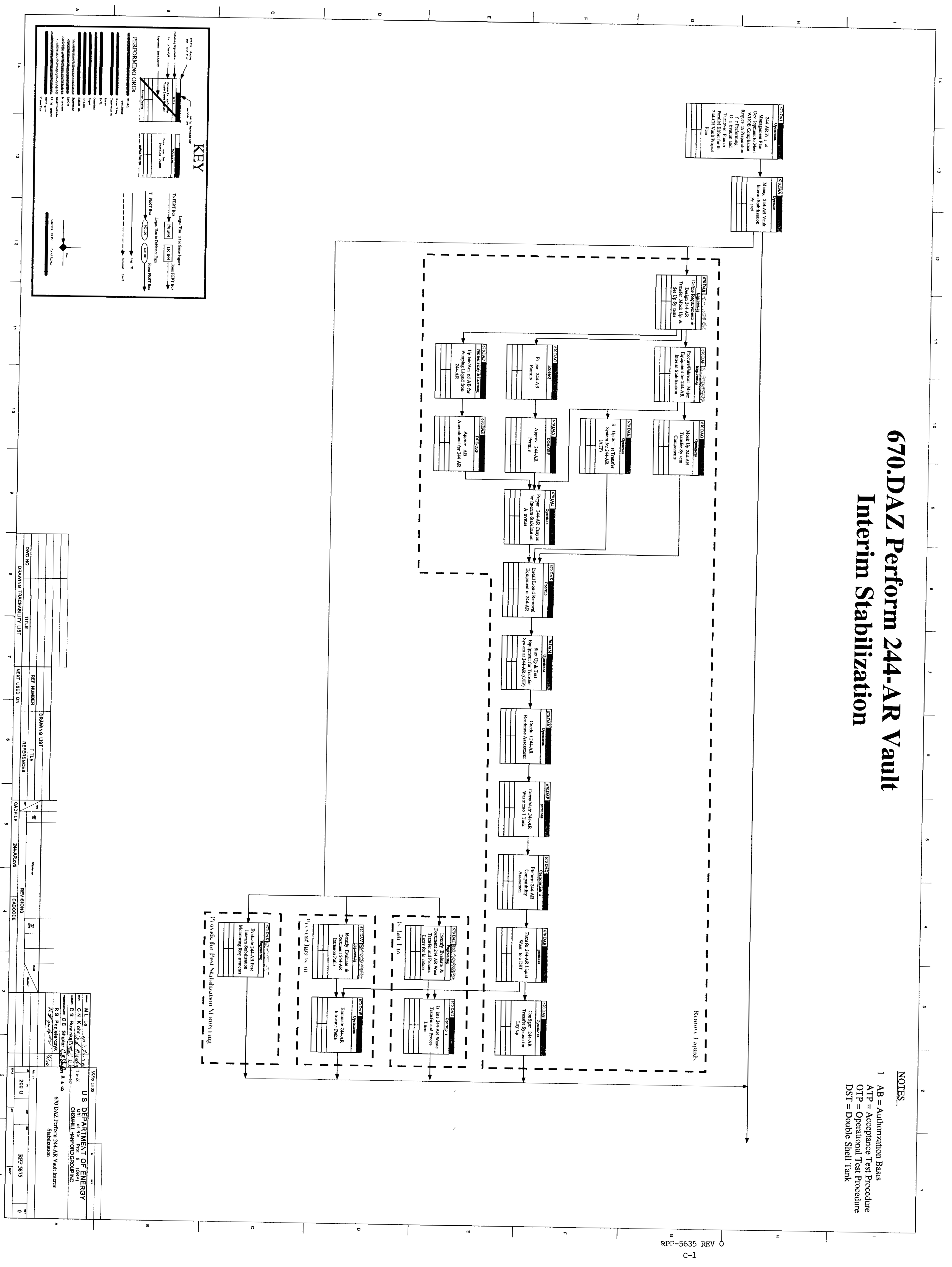




\begin{tabular}{|c|c|c|c|c|c|}
\hline \multicolumn{6}{|c|}{ DISTRIBUTION SHEET } \\
\hline \multirow[b]{2}{*}{ Distribution } & \multirow{2}{*}{\multicolumn{3}{|c|}{$\begin{array}{l}\text { From } \\
\text { Operations Configuration } \\
\text { Management/Field Upgrade }\end{array}$}} & \multicolumn{2}{|l|}{ Page 1 of 1} \\
\hline & & & & \multicolumn{2}{|c|}{ Date $\quad 03 / 23 / 00$} \\
\hline \multicolumn{4}{|l|}{ Project Title/Work Order } & \multicolumn{2}{|c|}{ EDT No. EDT-628386 } \\
\hline \multicolumn{4}{|c|}{$\begin{array}{l}\text { RPP-5635, Rev. 0, "244-AR Vault Interim Stabilization Project } \\
\text { Plan" }\end{array}$} & \multicolumn{2}{|c|}{ ECN No. $\quad \mathrm{N} / \mathrm{A}$} \\
\hline Name & MSIN & $\begin{array}{c}\text { Text } \\
\text { With } \\
\text { A11 } \\
\text { Attach. }\end{array}$ & Text OnTy & $\begin{array}{l}\text { Attach./ } \\
\text { Appendix } \\
\text { Only }\end{array}$ & $\begin{array}{l}\text { EDT/ECN } \\
\text { Only }\end{array}$ \\
\hline $\begin{array}{l}\text { CH2M HILL Hanford Group. InC. } \\
\text { D. I. ATlen } \\
\text { D. G. Baide } \\
\text { T. M. Bateman } \\
\text { C. DeFigh-Price } \\
\text { K. M. HaTl } \\
\text { S. M. Henry } \\
\text { J. O. Honeyman } \\
\text { C. J. Hopkins } \\
\text { T. Saney } \\
\text { C. E. Leach } \\
\text { E. E. Mayer } \\
\text { P. C. Mi 1 er } \\
\text { M. A. Payne } \\
\text { W. E. RosS } \\
\text { C. E. Shipler } \\
\text { T.C.S.R.C. }\end{array}$ & 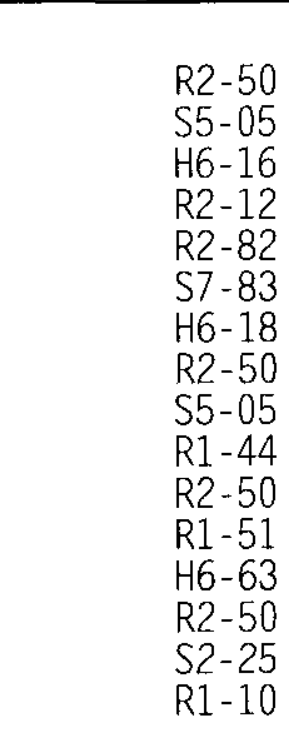 & $\begin{array}{l}x \\
x \\
x \\
x \\
x \\
x \\
x \\
x \\
x \\
x \\
x \\
x \\
x \\
x \\
x \\
x\end{array}$ & & & \\
\hline$\frac{\text { Lockheed Martin Services, Inc. }}{\text { Central Files }}$ & $B 1-07$ & $x$ & & & \\
\hline$\frac{\text { MACTEC }}{\text { D. S. Rewinke } 1}$ & S7-83 & $x$ & & & \\
\hline$\frac{\text { Office of River Protection }}{\text { DOE Reading Room }}$ & $H 2-53$ & $X$ & & & \\
\hline
\end{tabular}

